\title{
Project
}

\section{The Unauthorized Practice of Law and Pro Se Divorce: An Empirical Analysis*}

\section{TABLE OF CONTENTS}

Introduction

I. The Emergence of Pro Se Divorce Aids and the Response of the Bar

II. The Anatomy of a Monopoly: The Empirical Project

A. Methodology 116

B. Empirical Analysis $\quad 122$

1. Form Preparation and Court Proceedings Prerequisite to Dissolution

2. Ancillary Legal Issues $\quad 129$

a. Divorce Decrees 130

b. Separation Agreements 134

c. Legal Advice Regarding Ancillary Issues $\quad 137$

3. Summary of Findings Relevant to Unauthorized Practice Doctrine

III. Negotiation and Personal Counseling 141

IV. The Costs of the Lawyer Monopoly 153

V. Directions For Reform: The Limited Utility of Published Kits

Conclusion

* Funding for this Project was provided by the Russell Sage Foundation. The assistance of Professor Stanton Wheeler of the Yale Law School is gratefully acknowledged. 


\section{Introduction}

The widespread adoption of no-fault divorce statutes ${ }^{1}$ has been accompanied by the emergence of published kits and services designed to facilitate pro se marital dissolution. ${ }^{2}$ In many jurisdictions, however, the availability of inexpensive printed or personalized assistance ${ }^{3}$ has been severely limited by bar-initiated litigation under statutes proscribing the unauthorized practice of law. ${ }^{4}$ As a result, the recent demise of the fault-based system has removed the doctrinal but not the fiscal impediments to uncontested dissolution.

This Project evaluates the justifications for invoking unauthorized practice prohibitions in the context of pro se divorce. Part I discusses the impetus for divorce kits and services and describes the ensuing unauthorized practice litigation. Part II reviews the arguments marshaled in decisions enjoining the distribution of kits and the provision of personalized assistance, and tests the empirical validity of these arguments. Principal data sources are 331 uncontested divorce files from two Connecticut counties, questionnaires completed by 106 Connecticut attorneys, and telephone interviews with 99 lawyer-assisted divorce plaintiffs and 93 "do-it-yourself" divorce kit purchasers. This information is organized to isolate and illumine the discrete functions performed by lawyers in uncontested divorce actions. The Project concludes that the recent unauthorized practice injunctions have been based on assumptions which are not supported by the assembled data.

There may be justifications for the lawyer monopoly beyond those proffered in unauthorized practice litigation. In particular, Connecticut divorce lawyers who completed the Project questionnaire adverted to their negotiating and personal counseling functions. Part III em-

1. Only Illinois, Pennsylvania, and South Dakota retain exclusively fault grounds for divorce. In other jurisdictions, proof of voluntary separation or marital breakdown will suffice for a dissolution decree. For a complete listing of statutory requirements for dissolution in all states, see Freed, Grounds for Divorce in the American Jurisdictions, 8 FAM. L.Q. 401 (1973). Since the publication of that compendium, Massachusetts and Mississippi have modified their divorce statutes by introducing no-fault grounds. Mass. AnN. L.uws, ch. 208, $\$$ LA (Michie/Law. Co-op Supp. 1975) (irretrievable breakdown); Miss. Senate Bill No. 20-74, § I (1976) (irreconcilable differences) (on file with Yale Law Journal).

2. A list of kits and services which have been available at some point in 14 states appears in Appendix 1.

3. In some jurisdictions, whether or not assistance is "personalized," i.e., whether the agents of lay services personally assist customers, has proved a critical factor in the assignment of unauthorized practice liability. See pp. 112-13 infra.

4. See Appendix 1 . 
ploys data from attorney questionnaires and client interviews to critique these aspects of the attorney's role.

In Part IV the Project examines the adverse consequences of the present restrictions on lay divorce services. A fifth and final section summarizes the public policy considerations militating against the perpetuation of the lawyer monopoly over the procedural aspects of uncontested marital dissolution.

\section{The Emergence of Pro Se Divorce Aids and the Response of the Bar}

Traditionally, lawyers have been virtually indispensable agents in the formal dissolution of marriages. Prior to 1967, couples seeking a divorce were generally obliged to prove in court that one spouse's misconduct or abnormality had destroyed the viability of the marital relationship. ${ }^{5}$ Within this "fault"-imbued context, attorney functions included preparing the forms required for entry of a decree of divorce, compiling evidence of culpability and presenting it at trial, ${ }^{0}$ and capitalizing on the relevance of misconduct to achieve greater bargaining leverage in negotiations over financial and parental matters.

5. Common statutory grounds included adultery, physical or mental cruelty, conviction of certain crimes, habitual intemperance, insanity, and impotence. For a discussion of the requirements in various jurisdictions, see Wadlington, Divorce Without Fault Withvut Perjury, 52 VA. L. Rev. 32 (1966). By 1968, 22 states also permitted dissolution for couples who had lived apart for some prescribed statutory interval ranging from one to 10 years. M. Rheinstein, Mirriage Sribility, Divore,, IND THe L $1 W 314$ \& n.5 (1972). Given the extended mandatory separation periods, these provisions did not displace traditional fault grounds. As the Reporter for the Committee on Uniform Marriage and Divorce Laws of the Commission on Uniform State Laws observed: "So long as a perjured or coilusive, fault-based divorce is an alternative, many couples will want to take advantage of the more rapid alternative, and lawyers will find it difficult to resist such pressur.s." R. LEVY, Uniform M.ıRRIAGe AND Divorce Legislation: A Preliminary ANalysis 53 (1969).

6. For a description of the attorney's role in superintending courtroom attributions of guilt, see R. Felder, Divorce 124-200 (1971); M. Virtue, Family Cases in Court 27-29, 89-91 (1956); and Westman, The $M y t h$ of the Uncontested Divorce, 41 FL1. B.J. 304, 306-08 (1967). Cf. 1 L. Marshall \& G. May, The Divorce Court 170-94 (1932) (transcripts of court testimony adduced to establish fault). However, the distasteful necessity of proving marital misconduct at a full dress public hearing was to some extent avoidable. Attorneys representing affluent parties frequently referied their clients to jurisdictions with minimal residency and lax evidentiary requirements (e.g., Nevada and Mexico). N. Blake, The Road to Reno: A History of Divorce in the United Stites $152-72$ (1962). It was estimated in the mid-1960s that migratory divorces accounted for $11 \%$ of annual American dissolutions. Drinan, What are the Rights of the Involuntary Divorce? Reflections on Divisible Divorce, 53 K'x. L.J. 209, 213 (1965).

7. Fault grounds were susceptible to manipulative and extortionary use. For revealing, albeit popularized accounts, see D. Cantor, Escape From Miarriage $39-62$ (1971); R. Felder, supra note 6, at 13-20, 227 (1971); R. KAHN \& L. KAHN, THE Divorce LAwYeR's Casebook 91-93 (1972); S. Rosenblatt, The Divorce Racket 20-23, 50-51 (1969); N. Sheresky \& M. Mannes, Uncoupling 53-93 (1972); Phillips, Mental Hygiene, Divorce, and the Law, 3 J. FAM. L. 63, 65, 69-70 (1963). 
By the end of the 1960s, there was a growing consensus among scholars and practitioners that fault-based divorce was an irrational and unnecessarily demeaning process. ${ }^{s}$ Critics maintained that the adjudication of guilt increased acrimony between spouses, ${ }^{9}$ encouraged the use of children as bargaining pawns, ${ }^{10}$ created ethical tensions for the bench and bar, ${ }^{11}$ and eroded respect for the law generally. ${ }^{12} \mathrm{Be}$ tween 1967 and 1976, 47 states effectively removed fault impediments to dissolution by providing as grounds for divorce such criteria as incompatibility, irretrievable breakdown of the marriage, or a voluntary separation of short duration. ${ }^{\mathbf{1 3}}$

8. See, e.g., M. Rheisstein, supra note 5, at 406; Goldstein \& Gitter, On Abolition of Grounds for Divorce: A Model Statute \& Commentary, 3 F.M. I.Q. 75, 79-81 (1969); Note, Untying the Knot: The Catse and Patlerns of Divorce Reform, 57 CoRnell L. Rxv. 619, 653-54 (1972).

This consensus was echocd in the analysis prepared by the Reporter for the Committee on Uniform Marriage and Divorce Laws. R. Levr, supra note 5, at 9, 43-44, 52. The Committe had been appointed in 1966 by the National Conference of Commissioners on Uniform State Laws to draft a model marriage and divorce code. The Committee ultimately recommended that all the traditional fault grounds for divorce be replaced by a single no-fault criterion: irretrievable breakdown of the marriage. UNiform MARRIAGE AND Divorce ACT $\$ 302$, reprinted in 18 S.D. L. REv. 680, 683 (1973).

Although the model code adopted by the Commission was nerer endorsed by the $A B A$, see note 13 infra, its report and attendant reverberations in legal journals generated sentiment for the reforms that occurred between 1967 and 1976.

9. See sources citcd in note 7 supra.

10. See, e.g., M. YIRTur, supra note 6, at 44; Kay \& Phillips, Poverty and the Law of Child Custody, 54 C.tLif. L. Rev. 717, 740 (1966).

11. Matrimonial lawyers frequently faced an irreconcilable conflict between the expectations of their clients (who wanted a divorce whether or not they had a legally cognizable ground) and the canons of their profession (which proscribed advancement of perjurious or collusive claims). H. O'Gorman, L.WWyers ANd M.atrimonial Gases 30-32 (1963). For instance, under New York Icgislation that made adultery the sole ground for divorce until 1966, the temptation to conjure up "the familiar blonde in black silk pyjamas" was often irresistible. Drinker, Problems of Professional Elhics in Matrimonial Litigation, 66 H.trv. L. Rev. 443, 418 (1953). See also W. Gellhorn, Children and Families IN THE Courts of NEW York CITY 285-86 (1954) (quoting report of grand jury investigation which, after examining 600 files and 1500 witnesses, concluded that "fraud, perjury, collusion and connivance pervade matrimonial actions of every type"); N.Y. Herald Tribune, Oct. 1, 1965, at I9, col. I (report of testimony of state supreme court Justice Meier Steinbrink before state legislative committee regarding "farcical" situation which confronted matrimonial bench).

12. Because the law required that hearings be staged as adversarial clashes exen when the parties were in agreement, the court was left

presiding over a contest which is no contest at all ... and made to take part in a solemn if silly comic-melodrama, impatiently acted out as supcrficially and rapidly as possible by the participants. Such a performance is beneath the dignity of the American court, and it cheapens not only the tribunal but the members of the profession who are also involved in the ceremony.

M. Virtue, supra note 6, at 230. Sce also M. Ploscowe, The Truth Arout Divorce 247-50 (1955); Wadlington, supra note 5 , at $32-35$.

13. Statutory grounds for dissolution in these states are outlined in note 1 supra and sources cited therein. "Irretrievable breakdown" was the formulation urged by the Commission on Uniform State Laws. See note 8 supra. The definition and justiciability of this proposed no-fault criterion were points of contention between the Committee on Uniform Marriage and Divorce Laws and the ABA's Family Law Section. The Uniform 
Although in some jurisdictions certain procedural vestiges of the adversarial process were retained, ${ }^{14}$ no-fault legislation signaled a diminished role for attorneys in uncontested divorces. Reforms eliminating the need to adduce evidence of marital offenses in court, accompanied in some states by a simplification of pleadings, reduced the necessity for legal guidance in dissolution actions. ${ }^{15}$ And, as some members of the bar had predicted, ${ }^{16}$ attempts to oust attorneys from certain aspects of the divorce process soon followed. ${ }^{17}$

Support for pro se representation emerged from an inchoate alliance

Commission generally seeks ABA approval before lobbying for a particular model act. The Family Law Section was responsible for evaluating the Uniform Marriage and Divorce Act for the $A B A$; it recommended against $A B A$ ratification in 1970 . The bar's refusal to ratify represented the first rejection of a Commission proposal since the Commission's founding in 1892. Foster, Divorce Reform and the Uniform Act, 7 FAx. L.Q. 179,185 n.33 (1973).

After the defeat of the Act, a joint committee of $\mathrm{ABA}$ and Commission representatives was appointed to work out a compromise proposal. As amended by that committec, $\$ 305$ of the Uniform Act defined irretrievable breakdown as "no reasonable prospect of reconciliation," and mandated entry of a decree where both parties stated under oath that the marriage was irretrievably broken or where one party so stated and the other did not deny it. Id. at 194. The new proposal was still unacceptable to the Family Law Section. Henry Foster, Jr., co-chairman of the Section's research committee, opined that what the Commission reporters "really favored [was] administrative divorce upon request." Id. at 186. See also Podell, The Case for Revision of the Uniform Marriage and Divorce Act, 7 FAM. L.Q. 169, 171-72 (1973). The ABA again refused to ratify the Act in 1972, Foster, supra at 187, and proposed a counterdraft the same year, Proposed Rcviscd Uniform Marriage and Divorce Act (Submitted by ABA Family Law Seclion), 7 FaM. L.Q. 135 (1973) [hereinafter cited as Proposed Act]. A revised version of the Uniform Act was finally adopted by the ABA House of Delegates in February 1974. House of Delegates Acts on Group Legal Services, Shield Legislation, Court Organization Standards, and Uniform Divorce, 60 A.B.A.J. 446, 451 (1974).

14. A complaint, service by sheriff, and hearing in court are still required in Connecticut and other no-fault jurisdictions. See pp. 123-27 \& note 78 infra.

15. In cases where probative requirements could be satisfied by an attestation of separation for the statutory period or a stipulation of irretrievable breakdown, the nced for counsel was obviously reduced both before and during "trial." In the course of reform, a number of states also streamlined the mecharics of pleading. The impact in California was especially dramatic. A survey of court files in Alameda County from February 24 to April 9, 1971, revealed that six percent of the petitions werc pro se, as compared with $.5 \%$ in 1969 before the no-fault ground and procedural reforms were instituted. Goddard, A Report on California's New Divorce Lau': Progress and Problems, 6 FAM. L.Q. 405, 413 (1972). For data on the volume of pro se dissolutions in several states, including California, see note 25 infra. For further discussion of procedural requirements in no-fault divorce jurisdictions, see pp. 123-29 infra.

16. Attorney comments reported in M. Wheeler, No F.1LLT Drorce 117-30 (1974) suggest that an appreciable segment of the bar equated the arrival of no-fault legislation with a decline in legal fees. C. Mentrowski, Associate Dean of the Marquette Law School, chided reformers in the Family Law Section: "Behind it all, you can't see that it's really 'no lawyer'. Whether it's no-fault insurance law or administrative probate or now no fault divorce, you're all adrocating your own demise." Id. at 120. S. Schoonmaker, Chairman of the Connecticut Bar Association's Family Law Section, reported opposition to statutory reform from practitioners who charged several hundred dollars for divorcing couples of modest means. These lawyers felt that no-fault would "dry up this business" by permitting potential clients to divorce themselves. Id. at 123,124 .

I7. See Appendix 1. 
of feminists, ${ }^{18}$ family law reformers, ${ }^{19}$ consumer activists, ${ }^{20}$ and entrepreneurs. ${ }^{21}$ Receptivity to this option has undoubtedly been heightened by recent well-publicized assaults on the bar's protective pricing practices.22 As these monopolistic restrictions began to appear as a suspect rather than immutable characteristic of the legal profession, the climate for pro se dissolution grew more favorable. And in at least 14 states a market developed for do-it-yourself divorce kits and services. ${ }^{23}$

Assistance for pro se litigants has taken the form of published kits and personalized assistance in document preparation, ranging in price from $\$ 3$ to $\$ 180 .{ }^{24}$ Typically kits have contained samples of legal forms necessary to secure a decree of marital dissolution, together with instructions on how to complete them. Direct personal advice and

18. Feminists who have developed kits or clinics variously envision pro se divorce as providing an alternative to "outrageous", legal fees, WOMEN in Transition, INc., Women's Survival Manual: A Feminist Handbook on Separation and Divorce 45 (1973); a means of counteracting women's sense of incompetence and dependence, WOMEN's LEGAL CENTER of San francisco, Getring Out: A Collective Experience in Self-Help Divorce 3 (1974); and an occasion for encouraging women to question culturally conditioned role patterns. Id. at 13 (discussion of Seattle Women's Divorce Cooperative).

19. Nathaniel Denman, the founder of Family Law Reform, Inc. (Cambridge, Mass.), believes that divorce attorneys exhibit bias against men and extort unconscionable fees, based not on the time expended but on what the traffic will bear. The organization encourages individuals to proceed pro se and lobbies for changes that will obviate the need for professional intermediaries in divorce actions. M. WHEELE, supra note 16, at 117 .

20. Ralph Nader and Mark Green have endorsed institutional changes that will reduce reliance on lawyers for routine legal services such as title searches, simple wills, and uncontested divorces. Ralph Nader Reports, LAdies HoME J., Aug. 1975, at 36; Green, The High Cost of Lawyers, N.Y. Times, Aug. 10, 1975, $\$ 6$ (Magazine), at 8, 62. Similar sentiments have been expressed in academic circles. See Cahn \& Cahn, Power to the People or the Profession?: The Public Interest in Public Interest Law, 79 YALE L.J. 1005, 1019 (1970); see also Brickman, Of Arterial Passageways Through the Legal Profession: The Right of Universal Access to Courls and Lawyering Services, 48 N.Y.U. L. REv. 595, 641-56, 662-68 (1973).

21. See note 25 infra and cases cited in Appendix 1, all of which were actions against lay divorce entrepreneurs.

22. See, e.g., Goldfarb v. Virginia State Bar, 421 U.S. 773 (1975); Wash. Post, June 26, 1976, at $A 4$, col. 1 (civil antitrust suit filed by Justice Department on June 25, 1976 alleging that $A B A$ restrictions on advertising unlawfully restrained price competition among lawyers). Noteworthy as well is the ABA's decision in March 1975 to cease its ban on certain types of prepaid legal service plans (after being besieged by such groups as The Public Citizen and the National Consumer Center for Legal Services), Green, supra note 20, at 62; and its decision in February 1976 to permit certain forms of adrertising (including fee information), N.I. Times, Feb. 18, 1976, at 13, col. 1.

Further indices of the growing politicization of the issue of legal fees include inquiries by the Senate Judiciary Committee, The Organized Bar: Self-Serving or Serving the Public?: Hearings Before the Subcomm. on Representation of Citizen Interest of the Senate Comm. on the Judiciary, 93d Cong., 2d Sess. (1974), and the Nader counterconvention, held during the ABA's 97th annual convocation, which sought to dramatize the point that the Canons of Ethics operate like a "Canons of Profit" to protect lawyers at the expense of the public. Green, supra note 20 , at 57.

23. See Appendix 1.

24. For service and cost comparisons, see Appendix 1. 
clerical assistance in preparing these forms have also been made available by lay divorce businesses and feminist organizations. The result, in many jurisdictions, has been an appreciable and unprecedented surge of pro se divorce activity. ${ }^{25}$

Lay divorce entrepreneurialism and its challenge to the lawyer monopoly quickly attracted the attention of the organized bar. ${ }^{26}$ As divorce kits and supplemental services proliferated, they were met with a series of bar-initiated lawsuits seeking injunctions against what was asserted to be "the unauthorized practice of law." relief was generally forthcoming, and issued without exception if the challenged laymen were personally assisting individual divorce plaintiffs. ${ }^{28}$

These holdings are consistent with prevailing judicial definitions of unauthorized practice of law. Although successful unauthorized practice prosecutions before the Depression were directed almost ex-

25. In New York, former barber and furniture salesman James A. Winder opened four "Divorce Yourself" offices in 1972 which generated over 1,000 completed actions in a matter of months. Burke, New York "Divorce Yourself" Enjoined, 37 Un.uuth. Pruc. NEws 22, 22 (1973). A recent unpublished survey of San Mateo County (California) files revealed that $20 \%$ of the couples seeking divorces proceeded pro se. Friedman \& Percival, Who Sues for Divorce? From Fault Through Fiction to Freedom, 5 J. LEGAL STud. 61, 81 \& $n .33$ (1976). In an interview with the authors, a member of the California Divorce League (a consortium of lay divorce assistance businesses) indicated his understanding that at least 21 lay assistance offices were open throughout the state. Telephone Interview with Joseph M. Orr (Sept. 24, 1976) (notes on file with Yale Law Journal). Another spokesman for the League, Mitch Buszek, maintains that $30 \%$ of California dissolution actions are now filed pro se. Wall St. J., Sept. 3, 1976, at 1, col. 1, and 5, col. 2. A lay divorce office in Oregon handled approximately 600 clients per year before being sub. jected to judicial restrictions. See note 233 infra. Sources describing other kits and services are collected in Appendix 1.

26. Lawyers have a significant financial stake in the pro se divorce controversy. During the 12-month period between July 1975 and June 1976, there were 1,072,000 divorces in the United States. National Center for Health Statistics, HEW, Monthly Vital Statistics Report 1 (Aug. 27, 1976). In California, where the pro se divorce volume has been highest (see note 25 supra), the author of one divorce kit has estimated that those of his readers who conducted their own actions would otherwise have paid some $\$ 50$ million in legal fees. Wall St. J., Sept. 3, 1976, at 1, col. 1 .

27. See cases cited in Appendix 1.

28. - See id. An Oregon Court of Appeals holding is typical:

[A]ll personal contact between defendants and their customers in the nature of consultation, explanation, recommendation, or advice or other assistance in selecting particular forms, in filling out any part of the forms, or suggesting or advising how the forms should be used in solving the particular customer's marital problems does constitute the practice of law and must be and is strictly enjoined.

Oregon State Bar v. Gilchrist, 538 P.2d 913, 919 (Or. App. 1975).

Despite one successful California prosecution in 1973, State Bar v. Corey, No. 157163 (Cal. Super. Ct., Oct. 11, 1973), reprinted in 38 Unauth. Prac. News 44 (1974), lay divorce firms offering personalized form preparation assistance continue to operate on a large scale in the state. See note 25 supra. These concerns have had to contend with a vigorously enforced ban on divorce advertising, upheld as constitutional in Howard v. Superior Court, 52 Cal. App. 3d 722, 125 Cal. Rptr. 255 (1975). 
clusively against impersonators of attorneys, ${ }^{29}$ the scope of the doctrine has since expanded to proscribe the drafting of documents and the giving of advice related to legal rights. ${ }^{30}$ Although most lay divorce aids address themselves solely to the preparation of the standardized forms necessary for initiating and concluding a divorce action, ${ }^{31}$ the legal labels and formal functions of these documents render such activities readily classifiable as unauthorized practice. Other laymen

29. For a review of the statutes and case law of this period, see F. Hicks \& E. KuTz, Uniuthokized Prictice of Law (1934). One exception to the general policy of imposing sanctions only against those who fraudulently styled themselves "attorneys" or undertook to represent others in court is People v. Alfani, 227 N.I. 334, 125 N.E. 671 (1919) (holeling, over vigorous dissent, that nonlawyer who prepared legal papers as business had violated statute prohibiting unathorized practice of law).

During the Depression, the organized bar mounted a campaign to widen the scope of unathorized practice. See note 41 infra. The campaign was a response to increasing encroachment by banks, accountants, insurance companics, and real estate brokers upon many aspects of lawyer activity. Although these organizations and individuals made no serious attempt to supplant the attorney's exclusive right to represent litigants in court, they did aid clients in understanding and conforming with the intricate prescriptions of tax laws, commercial law, and gorernment regulations. For an account of lay incursions circa 1930, and the resulting impact on attorney incomc, see Hicks \& Katz, The Practice of Law by Laymen and Lay Agencies, 41 Y.LLE L.J. 69, 70, 71 n.9 (1931).

30. For purposes of defining unauthorized practice, courts harc typically cnumerated activitics common in a lawyer's office practice. E.g., W'est Virginia State Bar v. Earley, 144 W. Va. 504, 520, 109 S.E.2d 420, 431 (1959) ("Iegal advice and instructions to clients to inform them of their rights and obligations; preparation for clients of documents requiring knowledge of legal principles which is not possessed by an ordinary layman; and appearance for clients beforc public tribunals"). lior recent efforts at enumeration, sce State ex rel. Norvell v. Credit Bureau, 85 N.M. 521, 526, 514 P.2d 40, 45 (1973); and Hecomovich v. Nielscn, 10 Wash. App. 563, 571, 518 P.2d 1081, 1087, review denied, 83 Wash. 2d 1012 (1974).

On occasion, the prohibited activities are limited to those decmed "complex." For a review of the judicial dispute over whether complexity matters in fixing the bounds of unauthorized practice, sce J. Fischer \& D. L.IChMiN, UNisthokized Prictice Handook 111-48 (1972) [hereinafter cited as H.1Nobook].

31. Nearly all the published kits reviewed by the Project authors adrise customers to consult attorneys and lay specialists for information concerning ancillary legal matters such as taxes and complex property dispositions. See, e.g., C.alifornia Divorce Council, Minula for Dryokce introduction (1973); Divorce Refokm, Inc., Do Your Own Divorce

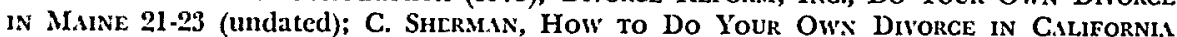
9 (1972); D. Willisus \& P. BLick, The \$27 Divorce 2 (1972) (Colorado); Womev's Legal Center of Sin Frincisco, Getting Out: A Collective Experience in Self-Help Divorce 7 (1974). But see C. Inlex, How to GrT A Nrw York Dworce For UNder $\$ 100$, at 24 (1973) ("Repeat: Exhaust every source of help you can before involving divorce lawyers.")

Personalized lay advice apparently has been marketed on a substantial scale only in California, New York, and Oregon. The founder of the California Divorce League, a consortium of California lay services, informed the Project authors that divorces involving disputes were "bcyond the scope of our services" and that plaintiffs with property complications were referred to attorneys. Telephone Interview with Ruth Ordesch (Dec. 18, 1975) (notes on file with Yale Law Joumal). Similar representations were also made by another spokesman for the California Divorce League in a recent newspaper interview. Wall St. J., Sept. 3, 1976, at 1, col. 1. Courts enjoining the personalized services of New York and Oregon lay advisors did not suggest that the interdicted activities transcended form preparation in uncontested cases. See State v. Winder, 42 App. Div. 2d 1039, 348 N.Y.S.2d 270 (i973); Oregon State Bar v. Gilchrist, 538 P.2d 913 (Or. App. 1975). 
involved in activities related to the practice of law have sometimes been granted exemptions by courts unwilling to interfere with services that are incidental to an established business (e.g., deed preparation by real estate brokers and tax advice by accountants).$^{32}$ But since lay divorce enterprises do not give legal advice in conjunction with other commercial services, the "incidental services" defense is unavailable to them..$^{33}$

When divorce advice is published rather than delivered in person, however, some courts have exempted it from unauthorized practice liability. ${ }^{34}$ Oregon $^{35}$ and New York ${ }^{36}$ decisions drawing this distinction relied upon the rationale developed in New York County Lawyers' Association v. Dacey. ${ }^{37}$ In Dacey, the New York Court of Appeals

32. In the main, these exceptions have been the product of bar association suits challenging advice or document preparation activities that constituted part of a wellestablished occupational practice. Although such activities are unambiguously legal in character, longstanding public reliance makes a prohibition difficult to justify on policy grounds. Sometimes courts have escaped the dilemma by deciding to balance costs and benefits accruing to the public from the performance of the challenged "incidental" act, Cowern v. Nelson, 207 Minn. 642, 647, 290 N.W. 795, 797 (1940) (conveyancing by realtors), or by taking the custom of the community into account when fixing the bounds of the practice of law, Lowell Bar Ass'n v. Loeb, 315 Mass. 176, 186, 52 N.E.2d 27, 34 (1943) (lay preparation of income tax returns). Cases accepting the incidental character of legal activities as an invitation to apply less stringent unauthorized practice standards are collected in HandBook, supra note 30, at 136-38, and discussed in Note, Lay Divorce Firms and the Unauthorized Practice of Law, 6 U. MICH. J.L. REF. 423, $428-29$ (1973). Cf. Hulse v. Criger, 363 Mo. 26, 45, 247 S.W.2d 855, 862 (1952) (maintaining that "the guiding principle" in unauthorized practice determinations is "whether under the circumstances the preparation of the [legal] papers . . . is the business being carried on or whether this really is ancillary to and an essential part of another business").

Many courts, however, have refused to grant special treatment to incidental services. See, e.g., State Bar v. Arizona Land Title \& Trust Co., 90 Ariz. 76, 93, 366 P.2d 1, 12-13 (1961), supplemented on rehearing en banc, 91 Ariz. 293, 371 P.2d 1020 (1962); Chicago Bar Ass'n v. Quinlan \& Tyson, Inc., 34 Ill. 2d 116, 122, 214 N.E.2d 771, 774 (1966); Hecomovich v. Nielson, 10 Wash. App. 563, 571-72, 518 P.2d 1081, 1087, review denied, 83 Wash. 2d 1012 (1974). These cases essentially adopt the rationale of the first Informative Opinion issued by the ABA's Committee on the Unauthorized Practice of Law, which maintained that any provision of legal instruments or legal advice by laymen is unauthorized practice, regardless of the circumstances. ABA CoMm. ON THE UNAUTHORIzED Practice of Law, Informative Opinions 1 (1960).

33. See Note, supra note 32, at 433 (concluding that incidental services exception "clearly does not apply to divorce firms"); Cf. Gardner v. Conway, 234 Minn. 468, 479-80, 48 N.W.2d 788, 796 (1951) ("[I]f the furnishing of the legal service is the primary business of the actor such activity is the practice of law, even though such service is of an elementary nature."); see also Note, Unauthorized Practice of Law and the Sale of Divorce Kits, 38 ALB. L. REv. 332, 340-41 (1974).

34. See Appendix 1. Regarding the application of unauthorized practice doctrine to legal publications generally, see Feigenbaum, Legal Advice Publications, 76 Dick. L. REv. 419, 423-35 (1972); and Ells, Unauthorized Practice of Law by Way of Publications Giving Legal Advice, 25 Unauth. PRac. News 295 (1959).

35. Oregon State Bar v. Gilchrist, 538 P.2d 913 (Or. App. 1975).

36. State v. Winder, 42 App. Div. 2d 1039, 348 N.Y.S.2d 270 (1973).

37. 21 N.Y.2d 694, 234 N.E.2d 459, 287 N.Y.S.2d 422, rev'g 28 App. Dir. 2d 161, 283 N.Y.S.2d 984 (1967). The New York Court of Appeals adopted in full the dissenting opinion filed below by Judge Stevens of the appellate division, 28 App. Div. $2 d$ at 171 , 283 N.Y.S.2d at 996. 
sustained the publication of a do-it-yourself estate planning kit. The Dacey court excluded publications from the ambit of unauthorized practice on the ground that "the essential of legal practice" was "the representation and the advising of a particular person in a particular situation." 38 But this analysis has been rejected in two Florida Supreme Court decisions enjoining pro se kits and services. ${ }^{39}$ These latter opinions emphasized the legal character of the form preparation advice offered by divorce kits. ${ }^{40}$

The policy considerations underlying judicial hostility to lay divorce services are somewhat unclear. Although the organized bar has always contended that its unauthorized practice campaign"1 is not a "trade union movement" but a service "in the public interest," 42 none of its

38. 28 App. Div. 2d 161, 174, 283 N.Y.S.2d 984, 998, dissenting opinion adopted, 21 N.Y.2d 694, 234 N.E.2d 459, 287 N.Y.S.2d 422 (1967). This analysis was drawn from an earlier Connecticut decision involving the same defendant, which enjoined the provision of personalized estate planning advice by nonlawyers. Grievance Comm. v. Dacey, 154 Conn. 129, 222 A.2d 339 (1967), appeal dismissed, 386 U.S. 683 (1967). The New York and Connecticut Dacey holdings are discussed in Feigenbaum, supra note 34, at 419-22, 42729; and Note, Unauthorized Practice of Law and the Sale of Divorce Kits, 38 ALB. L. REv. $332,333.35$ (1974).

39. Florida Bar v. Stupica, 300 So. 2d 683 (Fla. 1974); Florida Bar v. American Legal \& Business Forms, 274 So. 2d 225 (Fla. 1973). Cf. Palmer v. Unauthorized Practice Comm., 438 S.W.2d 374 (Tex. Civ. App. 1969) (sale of printed will forms enjoined as unauthorized practice).

40. Florida Bar v. Stupica, 300 So. 2d 683, 687 (Fla. 1974), held that the kits contained "direct legal instructions and advice" and "assume[d] an in lieu role in place and instead of an attorney at law." See Florida Bar v. American Legal \& Business Forms, $27 \pm$ So. 2d 225, 227 (Fla. 1973).

41. The chief proponent of an expansive construction of the unauthorized practice doctrine has been the organized bar. The ABA Committee on the Unauthorized Practice of Law was established in 1930 to marshal the energies of the profession in a campaign against competing lay services. AB.t Comm. on the Unauthorized Prictice of Law, Informative OpInIons 1 (1960). The Committee is still active. It brings no suits itself but is involved in public relations and publishes a periodical, Unauthorized Practice News, which contains form pleadings for use in litigation conducted by state and local unauthorized practice committees. Forty-nine state bar associations currently have active Unauthorized Practice of Law Committees. Public Information-State Unauthorized Practice of Law Committees-1973-74, 38 UnAuth. Prac. News 88-125 (1974). These state organizations both initiate litigation and investigate complaints made by local bar associations. The Florida committee reported five pending unauthorized practice cases, six concluded cases, and 190 completed investigations in the July-December 1974 interval alone. Florida Bar Reports a Very Busy Six Months of Activity on Unauthorized Practice of Law Matters, 39 Unauth. PRAc. News 152 (1975). These and similar efforts are in accord with the ABA directive that a "Lawyer Should Assist in Preventing the Unauthorized Practice of Law:" ABA Code of Profrssionil Responsibility Canon 3 (1975). This Canon is an expanded version of a 1937 amendment to the Canons of Ethics. ABA Canons of Professional Ethics No. 47.

42. Remarks of Hon. Orison S. Marden, past president of the Association of the Bar of the City of New York, reprinted in ABA National Conference on THE UnAUthorized Practice of LAw 14 (1962) [hereinafter cited as National Conference]. Frederick Buesser, Jr., chairman of the ABA's Committee on the Unauthorized Practice of Law, was quoted in a September 1976 interview as conceding that the bar's enforcement activities "do give the appearance that we are attempting to preserve our monopoly for our own cconomic purpose"; lie maintained, however, that such efforts were undertaken to 
suits against divorce concerns has developed a record of more than minimal mishaps attributable to lay assistance. ${ }^{43}$ And none of the judicial opinions in those cases challenged the accuracy of the published or verbal instructions at issue. ${ }^{44}$ Indeed, one court explicitly held that even a perfect record of consumer satisfaction would be "irrelevant." 45 Decisions have turned not on the quality of pro se kits or services, but on whether proffered advice is found to fall within the province of legal practice. ${ }^{46}$ Such a narrowly focused inquiry ignores

aclieve "what is the best thing for the public." Wall St. J., Sept. 3, 1976, at 1, col. I, and 5, col. 2. See West Virginia State Bar v. Earley, 144 W. Va. 504, 527, 109 S.E.2d 420, 435 (1959); Buesser, The "Kit" Age and Unauthorized Practice (Divorce, Will, and Corporation Kits), 39 UNAutr. Prac. News 12, 12 (1974). The ABA's Code of Professional Responsibility provides further evidence that the bar perceives itself as vindicating the public interest. For example, Ethical Consideration 3-1 states, in pertinent part:

Because of the fiduciary and personal character of the lawyer-client relationship and the inherently complex nature of our legal system, the public can better be assured of the requisite responsibility and competence if the practice of law is confined to those who are subject to the requirements and regulations imposed upon members of the legal profession.

Ab.t Code of Professional Responsibility lC 3-1 (1975). See id. EC 3-2 to 3-5.

There are, however, occasional concessions that the self-interest of the legal profession is a salient consideration in its vigilant pursuit of unauthorized practitioners: "[I]t must be remembered that there would not long be a highly trained legal profession to serve the public if the lawyers are going to have to compete with everyone who has a typewriter and a set of forms." National Conference, supra, at 27 (Warren Resh, editor of Unauthorized Practice News). See Gardner v. Conway, 234 Minn. 468, 478-79, 48 N.W.2d 788,795 (1951).

43. Efforts by state bar investigators in New York and Oregon to uncarth complaints from the literally thousands of pro se divorce plaintiffs assisted by kit sellers bore virtually no fruit. See Oregon State Bar v. Gilchrist, 538 P.2d 913, 918 (Or. App. 1975); Burke, New York "Divorce Yourself" Enjoined, 37 Unautr. Pr.1C. News 22, 27-28 (1973). Cf. Resh, More on Do-It-Yourself Divorce Kits and Services, 37 UNauth. Pric. New' 59, 69 (1973) (prior to filing of Oregon bar association suit, state Consumer Protection Division conducted preliminary investigation of kit purveyors and "found no suggestion" of illegality).

44. See, e.g., Oregon State Bar v. Gilchrist, 538 P.2d 913, 917 (Or. App. 1975) (if used properly, information and forms are effective). None of the decisions cited in Appendix 1 mention any inadequacies in lay form preparation advice.

45. State Bar v. Corey, No. 157163 (Cal. Super. Ct. San Bernadino County, Oct. 11, 1973), reported in California Restrains "No-Fault Divorce Consultation Service," 38 Unauth. Prac. News 44, 48 (1974).

46. Unauthorized practice opinions in contexts other than lay divorce services have long disregarded the absence of injury to customers. The following language is typical: "We shall not dwell on the adequacy of the advice given ... . The decision must rest on the nature of the services rendered and on whether they were inherently legal ... services." Application of New York County Lawyers Ass'n (In re Bercu), 273 App. Div. 524, 531, 78 N.Y.S.2d 209, 215 (1948); accord, Conway-Bogue Realty Inv. Co. v. Denver Bar Ass'n, 135 Colo. 398, 410, 312 P.2d 998, 1004-06 (1957); Grievance Comm. v. Dacey, 154 Conn. 129, 149-50, 222 A.2d 339, 350 (1966), appeal dismissed, 386 U.S. 683 (1967). Blanket condemnations of lay practitioners are almost nerer supported with specific examples of injury to the public. See, e.g., F. Hicks \& E. Katz, supra note 29, at 4; National Conference, supra note 42, at 119; Gardner v. Conway, 234 Minn. 468, 477-78, 48 N.W.2d 788, 794 (1951); Washington State Bar Ass'n v. Washington Ass'n of Realtors, 41 Wash. 2d 697, 699, 251 P.2d 619, 621 (1952). Two prominent scholars assert that in 
the more fundamental issue of whether proscribing lay assistance serves any public interest.

There are two possible policy justifications for invoking unauthorized practice doctrine to prevent laymen from offering advice to pro se divorce plaintiffs. Both rest on empirical assumptions. First, it can be argued that, despite the advent of no-fault reforms, marital dissolution remains an adjudicatory process. As such, it demands a lawyer's special expertise in guiding litigants through the conventions of an adversarial system. However compelling this argument may be with respect to contested divorces, it is of questionable merit when spouses are in agreement on the terms of their decree. Indeed, the conventions of contested litigation seem themselves anomalous where petitioner and respondent seek identical relief. ${ }^{47}$ For parties not in dispute, divorce pleadings and court hearings function not as opportunities to advance opposing interests, but simply as formal requirements to be satisfied in order to secure entry of a dissolution decree. Therefore, the initial argument for discouraging lay assistance in such cases must be based on the presumed intricacy of these procedures. Courts and commentators have asserted that the procedural complexities which inhere in divorce actions cannot be addressed by laymen without generating administrative burdens for courts and injuries to parties. ${ }^{48}$ The Project explores the empirical premises that underlie this proposition.

Second, it is often maintained that lawyers play an essential advisory role throughout the dissolution process which transcends their courtrelated function. Whether contested or not, divorces may involve significant ancillary issues. Opponents of pro se divorce argue that guidance concerning parental and property matters demands legal training. ${ }^{40}$ While the importance of the rights affected by divorce is universally acknowledged, the contribution made by lawyers to their disposition is again an empirical proposition which this Project ad-

fact the public has typically benefited from access to lay legal services. Q. Johnstone \& D. Horson, Lawyiks and Turir Work: An Analysis of thic Profession in the Unitrd Stites ind England 194 (1967).

47. These conventions are defensible only insofar as they further cognizable state concerns, such as those articulated by the Family Law Section of the ABA in its Proposed Uniform Marriage and Divorce Act: to "promote the amicable settlement of disputes" between divorcing parties, and to "mitigate the potential harm to the spouses and their children caused by the legal dissolution of marriage." Proposed Act, supra note 13, at 136. Whether adrersarial procedures advance these interests by forcing parties to securc useful attorney assistance is an empirical question largely unexplored to date: it constitutes a central inquiry of this Project.

48. See p. 123 infra.

49. See pp. 129-30 infra. 
dresses. The fundamental question is whether requiring all dissolution plaintiffs to pay for an attorney's expertise and fiduciary responsibilities $^{50}$ secures sufficient benefits to outweigh the potential advantages of widespread public access to inexpensive pro se divorce assistance.

II. The Anatomy of a Monopoly: The Empirical Project

\section{A. Methodology}

The Project authors designed an empirical study to test the policy assumptions underlying recent applications of unauthorized practice doctrine to pro se divorce kits and services. The goals of the inquiry were:

a) to examine the lawyer's form preparation, legal advice, and other functions in uncontested ${ }^{51}$ no-fault divorce proceedings, and to assess whether these functions justify the perpetuation of a professional monopoly; and

b) to investigate the characteristics and experiences of a group of divorce kit purchasers.

To evaluate lawyer contributions in uncontested divorce actions, the authors drew upon three sources of data: a random sample of dissolution files for cases heard in the New Haven and Bridgeport

50. The fiduciary consideration has played a major role in unauthorized practice cases distinguishing between published and personalized legal advice. See New York County Lawyer's Ass'n v. Dacey, 28 App. Div. 2d 16I, 174, 283 N.Y.S.2d 984, 998, rev'd, 21 N.X.2d 694, 234 N.E.2d 459, 287 N.Y.S.2d 422 (1967) (published legal advice held not to constitute practice of law because it did not actuate "that relation of confidence and trust so necessary to the status of attorney and client"). The Dacey holding was followed in subsequent New York and Oregon decisions permitting the publication of divorce kits. See p. 112 supra. The pleadings in a recent bar association suit emphasized the importance of the fiduciary lawyer-client relationship to divorce plaintiffs. See Colorado Bar Association Starts Suit Against Lay Divorce Specialists, 39 UNdutr. Prdc. News 87, 91 (1975). See generally ABA Code of Professional Responsibirity EC 3-3, 3-4 (1975).

The necessity of imposing a fiduciary relation in the context of divorce form processing is questioned at p. 140 infra. The importance of fiduciary safeguards for parties desiring advice about financial and parental maters is not discussed in the Project, since no attempt has been made by any lay divorce agency to render such assistance. But it should be noted that many individuals who are now consulted frequently on these questions-such as social workers, accountants, and real estate agents-are not bound by the Code of Professional Responsibility.

51. The term "uncontested" is used throughout the Project in its legal sense: at the time the actions studied were claimed for a hearing, no responsive pleadings had been filed by the defendant or his attorney, and the defendant offered no objections at the hearing to the settlement presented for judicial ratification. It cannot, of course, be inferred from the absence of legal contest that no disputes existed during the pendency of the proceeding. See pp. 142-45 infra. 
(Connecticut) Superior Courts, ${ }^{52}$ questionnaires mailed to lawyers who represented the plaintiffs in the sampled cases, and interviews with almost a third of these plaintiffs.

The Project's sample of uncontested divorces contained 331 court files ${ }^{53}$-about $25 \%$ of the uncontested cases handled by private attorneys in New Haven and Bridgeport between April 1 and September $30,1975 .{ }^{5 t}$ These cases will hereinafter be referred to as "lawyerinitiated" divorces. Forty-six dissolutions conducted by legal aid attorneys were also surveyed, ${ }^{55}$ and will receive separate consideration where appropriate.50 Information available from the court files included duration of marriage, number of minor children, content of awards requested and granted, and provisions of separation agree-

52. All the divorces surveyed for the Project were recorded in Connecticut, which provides two no-fault grounds for marital dissolution: that "[t]he marriage has broken down irretrievably" and that "the parties have lived apart for ... eighteen months ... by reason of incompatibility." Nine fault grounds are still available. Cons. Gen. Srut. $\$ 16 \cdot 32$ (1975).

In $: 974,49 \%$ of the divores recorded in Connecticut occurred in the two counties served by the New Haven and Bridgeport courts. St.tre of Connecticut, 127tr RegistraTION REPORT 191 (1974). The New Haven sample was generated by randomly extracting 199 file numbers from the uncontested divorce calendars for the interval of April 1, 1975 through September 30, 1975. In Bridgeport, where court calendars are not saved for recordkeeping purposes, a search was conducted of randomly selected groups of file numbers which ultimately produced 200 divorces heard during the surveyed period. The equal size of the initial Bridgeport and New Haven file samples reflects the fact that the two counties have been gencrating virtually identical dissolution caseloads in recent years. Id.; State of Connecticut, 125th Registration Report 191 (1972).

53. An initial sample of 399 files (see note 52 supra) was reduced to 331 by removing files for divorces handled by legal aid attorncys and by eliminating from consideration files for contested divorces. There remained 160 New Haven and 171 Bridgeport files, representing dissolutions which were both uncontested and conducted by private attorncys.

The initial New Haven sample of 199 divorces contained 38 legal aid cases, while the 200 Bridgeport files produced only eight. The low Bridgeport total is largely attributable to staffing difficulties which plagued the local legal aid office throughout the months selected for study. Telephone Interview with David Snyder, Fairfield County Legal Services attorney (Feb. 2, 1976) (notes on file with Yale Law Journal). The contested divorces, on the other hand, were concentrated in the Bridgeport sample, because it had been compiled without the aid of uncontested court calendars. See note 52 supra. Although data was gathered only on those actions in which decree forms were labeled "uncontested," 21 of the 200 Bridgeport files nevertheless contained answers and crosscomplaints which were not withdrawn until after the case was claimed for a hearing. Such pleadings usually signal serious financial or custodial battles, making the proceedings in which they appear inappropriate for an assessment of private lawyer performance in uncontested divorces. In New Haven computerized court calendars which excluded all such formally contested cases were available. Only one contested case appeared in the sample, presumably reflecting a coding crror by the clerk's office.

54. This figure is derived from a count of actions listed in the New Haven uncontested calendars which were initiated by private attorneys and an extrapolation of the comparable Bridgeport volume. The Bridgeport computation was made by determining the relation between the total number of civil action files in the court archives and the subset checked in the search for uncontested divorce actions. See note 52 supra.

55. See note 53 supra.

56. Data from the legal aid divorces are presented and discussed at pp. 158-60 infra. 
ments. ${ }^{57}$ In the course of transcribing this information, an occasional datum was inadvertently omitted. Certain Project calculations, therefore, proceed from a base which excludes a few files. Wherever this occurs, the number of excluded files (rarely more than one percent of the sample) is specified.

To obtain a second source of data, 104 of the 331 plaintiffs in the lawyer-initiated sample were contacted by phone. The remainder were either not listed in the files of the telephone company, had unpublished phone numbers, or were otherwise unavailable. ${ }^{58}$ Ninety-nine of the individuals contacted consented to be interviewed. They are hereinafter denominated "interviewed clients." The low refusal rate $(5 \%)$ militates against the possibility of self-selection, a major source of bias in other empirical studies on divorce. ${ }^{50}$ Interviewed clients were questioned concerning, inter alia, the amount of contact they had with their attorneys, the extent to which their settlements were influenced by such contact, and the size of the fee charged for attorney services. ${ }^{00}$

The sample of interviewed clients did not underrepresent plaintiffs who experienced relatively complex divorces, i.e., those divorces in which the scope for lawyer contributions would presumably be greatest. In fact, comparisons with the total class of cases from which the interviews were drawn indicate that the reverse was true. ${ }^{61}$ Interviewed clients tended to be married longer, were more likely to own homes, and had a representative allotment of minor children (present in about

57. Appendix 2 lists all categories of data recorded.

58.

TABLE A

Plaintiffs in Lawyer-Initiated Divorces: Results of Search

Reached by Phone and Interviewed

Reached by Phone, Refused Interview

No Answer*

No Listing

Unpublished Phone Number

Total

"At least five efforts were made to reach every "no answer" plaintiff. The calls were made at different times of day over a two-week period.

59. That a majority of lawyer-assisted plaintiffs were not interviewed by the authors is attributable to the imperfections of the search technique, see note 58 supra, and not to a dearth of cooperation. In contrast, Goode's study of divorced women in metropolitan Detroit was hampered by a 19\% refusal rate, W. Goode, AFrer Divorce 352 (1956); and the questionnaires mailed in a Wisconsin survey were returned by only $18.5 \%$ of addressees, N. Kohut, Divorce for the Unbroken Marriage 18 (1973).

60. The form used in conducting these interviews is attached as Appendix 3.

61. Phone listings were most difficult to secure for those plaintiffs who shifted residence shortly after the recording of their divorce decree. Factors tending to decrease mobility (i.e., age, children, duration of marriage, and home ownership), would also conduce to greater complications in divorce actions. 
$50 \%$ of the cases).$^{62}$ Finally, although incomplete demographic data in the court files preclude comparative analysis, the interviewed plaintiffs reported enough short pre-filing separations $(64 \%$ under six months) and high joint incomes ( $38 \%$ over $\$ 15,000)$ to ensure substantial representation for these indicators of potential divorce complexity. ${ }^{03}$

62. The following table compares the entire sample of lawyer-initiated divorces with the subset of files pertaining to divorces of interviewed clients.

\section{TABLE B}

Comparison of All Lawyer-Initiated Files and Files for Interviewed Clients*

\section{Characteristic}

1. Female Plaintiff

2. Marriage Duration over 10 Years

3. Children Involved

4. Home Ownership Noted in File

5. Defendant Represented by an Attorney

6. Divorce Not Claimed for a Hearing within Five Months of Complaint

7. Decree Contains Property Award

8. Decree Contains Child Support Award in Excess of $\$ 50 / w k$

\begin{tabular}{cc}
\multicolumn{2}{c}{ Relative Frequency } \\
\hline & Files of \\
All Lawyer- & Interviewed \\
Initiated Files & Clients \\
$(\mathrm{n}=331)$ & $(\mathrm{n}=99)$ \\
$68.6 \%$ & $71.7 \%$ \\
$34.9 \%$ & $40.0 \%$ \\
$(\mathrm{n}=324)^{\mathrm{a}}$ & $(\mathrm{n}=95)^{\mathrm{b}}$
\end{tabular}

$\begin{array}{cc}48.7 \% & 49.5 \% \\ (\mathrm{n}=330)^{\mathrm{a}} & \\ 35.3 \% & 54.5 \% \\ & \\ 43.9 \% & 50.0 \% \\ (\mathrm{n}=330)^{\mathrm{a}} & (\mathrm{n}=98)^{\mathrm{b}} \\ 43.3 \% & 40.6 \% \\ (\mathrm{n}=312)^{\mathrm{c}} & (\mathrm{n}=96)^{\mathrm{b}} \\ 23.9 \% & 36.4 \% \\ 14.1 \% & 17.5 \% \\ (\mathrm{n}=325)^{\mathrm{a}} & (\mathrm{n}=97)^{\mathrm{b}}\end{array}$

* The disparitics in frequency of home ownership and property awards are statistically significant at the .001 and .02 levels respectively. The other contrasts displayed in Table $B$ are not significant at the .05 Ievel.

"Base is less than 331 due to the exclusion of files for which data were inadrertently omitted.

¿ Base is less than 99 due to the exclusion of files for which data were inadvertently omitted.

- Base is less than 331 because data on the dates divorces were claimed for a hearing were not collected from the first 19 files surveyed.

63. Parties who have been scparated for a substantial interval before filing for divorce are more likely to have disposed of jointly owned property and to have reached an accommodation concerning financial and parental matters. For parties in a relatively high income bracket, there usually will be more tangibles to divide and a heightened probability of tax complications. See generally Basi \& Weinstein, The Internal Revenue Code and Its Impact on Diuorce Setllements, 53 Taxss 132 (1975); Meckex, Federal Income Tax Implications of Divorce, 14 W.sshburN L.J. 219 (1975). 
Questionnaires were sent to the 218 lawyers who represented the 331 plaintiffs in the randomly sampled cases. One hundred and twelve $(51 \%)$ of the attorneys responded, and 106 returned completed questionnaires. ${ }^{64}$ The 158 files handled by respondent lawyers were then compared with the total pool of lawyer-initiated files; no major contrasts emerged. ${ }^{65}$

In Table $\mathrm{C}$, the income distribution among interviewed client families is compared with that among families nationwide in 1974.

\section{TABLE C}

Income Distributions for Interviewed Client Families and All United States Families

$\begin{array}{lcr} & \text { All Families* } & \text { Interviewed Clients } \\ \$ 0-5,000 & 13.0 \% & 3.1 \% \\ \$ 5,000-10,000 & 22.6 \% & 24.7 \% \\ \$ 10,000-15,000 & 24.3 \% & 34.0 \% \\ \$ 15,000+ & 39.8 \% & 38.1 \%\end{array}$

- Adapted from Bureau of the Census, Statistical Abstract of the United States 390 (1975).

a Base is less than 99 due to the exclusion of two interviews in which no response was given.

The atypical (by national standards) wealth of Connecticut residents made it likely that a substantial percentage of sampled divorces would involve the ancillary financial issues which cause concern among critics of pro se dissolution. The state ranks third in the United States in per capita income. BurEau of THE Census, Stitisticil Abstrict of THE UNITED STATES 388 (1975).

64. Four of the 218 questionnaires never reached the addressces. Of a total of 112 questionnaires returned, one was damaged in the mails, and five were not completed because, according to recipients, their disorce practices were too minimal to permit meaningful generalization.

On the average, respondent lawyers respresented 17 divorce plaintiffs per year and had 12 years of experience with divorces. They reported practices spread more or less evenly across the three categories of single practitioner, one to three partners, and four or more partners.

65.

TABLE D

Comparison of All Lawyer-Initiated Files and Files Handled by Respondent Lawyers*

\section{Characteristic}

I. Female Plaintiff

2. Marriage Duration over 10 Years

3. Children Involved

4. Home Ownership Noted in File

5. Defendant Represented by an Attorney

6. Divorce not Claimed for a Hearing Within Five Months of Complaint

\begin{tabular}{cc}
\multicolumn{2}{c}{ Relative Frequency } \\
\hline & Files Handled \\
All Lawyer- & by Respondent \\
Initiated & Lawyers \\
Files $(\mathrm{n}=331)$ & $(\mathrm{n}=158)$ \\
$68.6 \%$ & $68.3 \%$ \\
$34.9 \%$ & $32.0 \%$ \\
$(\mathrm{n}=324)^{\mathrm{a}}$ & $(\mathrm{n}=153)^{\mathrm{b}}$ \\
$48.7 \%$ & $51.6 \%$ \\
$(\mathrm{n}=330)^{\mathrm{a}}$ & $(\mathrm{n}=157)^{\mathrm{b}}$ \\
$35.3 \%$ & $43.7 \%$ \\
$43.9 \%$ & $49.0 \%$ \\
$(\mathrm{n}=330)^{\mathrm{a}}$ & $(\mathrm{n}=157)^{\mathrm{b}}$ \\
$43.3 \%$ & $45.3 \%$ \\
$(\mathrm{n}=312)^{\mathrm{c}}$ & $(\mathrm{n}=150)^{\mathrm{b}}$
\end{tabular}


Ethical strictures precluded an attempt to obtain information from attorneys regarding specific divorce cases. ${ }^{66}$ Rather, questionnaire recipients were asked to characterize certain aspects of their divorce practices. Estimates were requested regarding (1) the frequency of interspousal disputes over custody, property, and support orders in uncontested actions; and (2) the average amount of time spent per uncontested divorce on various tasks, including conversations with the client, preparation of forms, and negotiations with the defendant or his attorney. The questionnaire concluded with an open-ended query which invited the writer to identify "the lawyer's most important functions in an uncontested divorce action." 67

In pursuing the Project's second major line of inquiry, the pro se divorce phenomenon, the authors sought assistance from the New Haven Women's Center. The Center, which had compiled and marketed the only do-it-yourself divorce kit available in Connecticut, ${ }^{68}$ provided a list of 199 kit purchasers. Ninety-five were reached by phone, and $93(98 \%)$ cooperated with the interviewer. ${ }^{69}$ Twenty-three

7. Decree Contains Property Award

8. Decree Contains Child Support Award in Excess of $\$ 50 / w k$

$$
\begin{array}{cc}
23.9 \% & 24.7 \% \\
14.1 \% & 14.7 \% \\
(\mathrm{n}=325)^{\mathrm{a}} & (\mathrm{n}=156)^{\mathrm{b}}
\end{array}
$$

* Of the eight comparisons displayed in Table B, none are statistically significant at the .02 level. Only the home ownership differential is significant at the .05 level.

${ }^{a}$ Base is Iess than 331 due to the exclusion of files for which data were inadvertently omitted.

'Base is less than 158 due to the exclusion of files for which data were inadvertently omitted.

c Base is less than 331 because data on the dates divorces were claimed for a hearing were not collected from the first 19 files surveyed.

66. ABA Codr of Professional Responsibility Canon 4 (1975). ("A Lawyer Should Preserve the Confidences and Secrets of a Client.")

67. The questionnaire is reproduced in Appendix 4.

68. Pro Se Dissolution Group, Pro Se Dissolution Kit (1975). The kit's contents are cletailed in note 224 infra. Sales to the general public began in March 1975, although a few pro se plaintiffs obtained divorces as early as December 1974 with a preliminary version of the kit. Included in the four-dollar packet are samples of the forms required for a dissolution decree, coupled with instructions on completion and filing in court. The kit also explains the mechanics of the court hearing which precedes issuance of a decree. Women's Center personnel provide no clerical or form-completion assistance to purchasers.

69.

TABLE E

\section{Divorce Kit Purchasers: Results of Search}

Reaclied by Phone and Interviewed

Reached by Phone, Refused Interview

No Answer*

No Listing

Unpublished Phone Number

Total

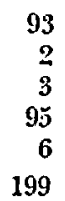

"At least five efforts were made to reach every "no answer" kit purchaser. The calls were made at different times of day over a two week period. 
of those interviewed had already obtained a dissolution decree with the aid of the kit's instructions; 21 were in the process of doing so. The remaining 49 had decided, for varying reasons, to postpone or reject kit use. The Project's data summaries for the pro se sample do not include the latter group, which will be treated separately. ${ }^{70}$

Interviews with kit purchasers were structured to elicit motivations for dispensing with lawyer assistance, to probe for possible complications arising out of the decision to proceed pro se, and to discover whether the pro se plaintiffs differed from their lawyer-assisted counterparts in terms of education, income, duration of marriage, or age. ${ }^{71}$

To supplement the interviews, the authors examined the court files for all pro se divorces recorded in the New Haven Superior Court between December 1, 1974 and October 31, 1975.72 Of the 31 divorces located, three had been accomplished without resort to the Women's Center kit. ${ }^{73}$ The individuals responsible were contacted by phone, bringing the Project's pro se interview sample to 96.

\section{B. Empirical Analysis}

The use of unauthorized practice doctrine to prohibit lay divorce kits and counseling rests on certain empirical assumptions concerning the nature and extent of attorney participation in dissolution proceedings. Those assumptions will form the organizing principles for this section.

Since the form preparation aspect of the lawyer monopoly is the only one to have been seriously challenged by laymen, it constitutes the crux of the unauthorized practice controversy. The principal arguments for proscribing lay assistance rest on assumptions concerning the need for professional expertise in document selection and completion. Initial consideration is, therefore, given to the legal forms necessary for a dissolution. The Project then assesses lawyer involvement in the allocation of financial and parental rights which may be involved in uncontested divorce proceedings. The importance of attorney attention to such ancillary matters is often invoked as a justification for excluding lay advisors from all aspects of the dissolution process.

70. See pp. 162-63 infra.

71. The forms used in conducting the interviews constitute Appendix $\mathbf{5}$.

72. No pro se divorces were heard in Bridgeport Superior Court during the period investigated.

73. In interviews with the authors, these plaintiffs indicated that they had mastered the necessary procedures by consulting the Connecticut Practice Book, a guide for practitioners available at local law libraries. 


\section{Form Preparation and Court Proceedings Prerequisite to Dissolution}

To secure an uncontested divorce decree in Connecticut, parties must file several standardized documents which initiate the action, claim it for a hearing in court, and record the terms of the dissolution. Instructions to pro se plaintiffs concerning these forms constitute the substance of the New Haven divorce kit. In other jurisdictions, published and oral advice of a similar nature has been the focus of unauthorized practice litigation. ${ }^{74} \mathrm{~A}$ representative judicial opinion concerning lay divorce services concluded that "filling out any part of the forms, or suggesting ... how the forms should be used . . . does constitute the practice of law and must be ... strictly enjoined."7s

The rationale for prohibiting such document preparation advice is that the complexity of form completion necessitates an attorney's assistance. As the Supreme Court of Florida observed:

It is a fallacy to look upon these documents and court pleadings as "mere forms", as if they were some kind of identification card.

$\ldots$

... A pleading, or adoption of a particular document to use, however seemingly "simple", has often involved extensive research and an evaluation of alternatives which were discarded as inadvisable. ${ }^{70}$

In a similar vein, the editor of the American Bar Association publication Unauthorized Practice News predicts that form processing errors would be an "inevitable" consequence of lay-assisted pro se divorce, resulting in a "terrific burden ... on the courts and court personnel." 77

An examination of the documents underpinning a Connecticut divorce, ${ }^{78}$ however, raises serious questions about the necessity of reserving form completion exclusively to lawyers. The analysis begins with a discussion of the complaint, claim for trial, and decree forms,

74. See pp. 110-15 supra.

75. Oregon State Bar v. Gilchrist, 538 P.2d 913, 919 (Or. App. 1975).

76. Florida Bar Ass'n v. American Legal \& Business Forms, 274 So. 2d 225, 227 (Fla. 1973).

77. Resh, Do-It-Yourself Divorce Kits and Services, 47 W' 1 . B. BuLL. 23, 23-24 (1974).

78. A survey of divorce kits from other jurisdictions suggest that Connecticut procedures are not atypical, although there are some variations in the labeling of forms and the manner in which they must be filed. Compare the descriptions in California Divorce Council, supra note 31; Divorce Reform, INC., supra note 31; and D. Williams \& P. Black, supra note 31. See Florida Rules of Court, Forms 1.943, 1.975, 1.995 (1975). See also Pagel, A Proposal for Reducing the Cost of Legal Representation in Divorce Proceedings, 11 WILLAMETTE L.J. 344, 346 (1975). 
which are requisites in all actions and were the only instruments involved in $30 \%$ of the sampled divorces. ${ }^{79}$

The divorce commences with a complaint. The complaint issues on a sheet of ruled legal-sized paper containing two punched holes of meticulously specified diameter and locale, ${ }^{\text {s0 }}$ and must be "substantially in accord" with Form 396 of the Connecticut Practice Book. ${ }^{81}$ An attorney or pro se plaintiff's responsibilities concerning Form 396 are complete when he has filled in the addresses of the parties, the maiden name of the wife, the date and place of the marriage, the grounds for the divorce, the names of any minor children, and the claims for relief.82 There are 11 grounds for divorce in Connecticut, but "irretrievable breakdown" of the marriage was offered as the sole basis for dissolution in $81 \%$ of the lawyer-initiated cases and in all of the pro se complaints examined by the authors. ${ }^{83}$

The only aspect of the complaint which might prove at all problematic to laymen is the section requiring the petitioner to list the "reliefs" desired. A pro se plaintiff conceivably could fail to make an appropriate request for child support, alimony, or a division of property. But such omissions occurred frequently in the lawyer-initiated divorces, with no apparent ill effects. In 29\% of the 131 lawyerinitiated cases in which no property or support adjustment was claimed by either party at any time before the hearing, such provisions were nonetheless incorporated in the decree of divorce.

The pro se plaintiffs who received divorces in the surveyed period negotiated Form 396 without difficulty. ${ }^{84}$ The greatest impediment proved to be the recently enacted statutory requirement that a dissolution complaint be signed by "a commissioner of the superior court or

79. These three forms need not be supplemented unless the action involves children, financial orders, or a spouse absent from the jurisdiction. Procedures governing these more complex cases are outlined at pp. 127-28 infra.

80. Connecticut Practice Book $\$ 79$ (1975).

81. Id. $\S 374$.

82. A copy of Form 396 is attached in Appendix 6.

83. Connecticut statutory provisions make the choice of grounds potentially relevant in actions featuring battles over finances and custody, since the judge is granted discretion to take the cause for dissolution into account when assigning custody or distributing property, ConN. GeN. Stat. $\$ \S 46-42,-51$ (1975). Fault is omitted as a consideration with regard to child support awards. $I d$. $\S 46-57$. Two complaints in the sampled lawyerinitiated cases attempted to imbue the "irretrievable breakdown" ground with fault connotations by ascribing the breakdown to the defendant's unspecified "misconduct." For a critique of fault vestiges in nominally no-fault systems, see $R$. LEvY, supra note 5 , at 52 .

84. The only pervasive problem appeared to be the spelling of "irretrievable breakdown." One pro se plaintiff was admonished for using the wrong size of paper, and another omitted a mandatory datum and was told by the clerk to retype his complaint. 
a judge or clerk of the court to which it is returnable."\$s Commissioners of the superior court are lawyers licensed to practice in Connecticut. A review of the court files indicated that New Haven pro se plaintiffs had solved this problem by obtaining the signature of a superior court clerk. But one out of the total of 47 interviewed pro se plaintiffs, 13-all of whom resided in counties outside New Havenreported significant difficulties in obtaining the necessary signature. ${ }^{86}$

Upon completion, the complaint must be served on the defendant. ${ }^{87}$ Pro se and lawyer-assisted plaintiffs alike typically obtained service of process by paying a sheriff between $\$ 10$ and $\$ 50$ to place the complaint in the hands of the defendant spouse. Occasionally, service was made by registered mail or publication. ${ }^{8 s}$

After 90 days, cases may be claimed for a hearing by filing Form $\mathrm{JD}$ (COLP)-6002 with the clerk of the superior court to which the complaint was returned. ${ }^{89}$ Form JD(COLP)-6002 requires an attestation that: (a) the case is uncontested; (b) all residence requirements have been met; ${ }^{00}$ and (c) 90 days have passed since the return date on the complaint. These attestations are made by placing an " $\mathrm{x}$ " in the

85. Conn. Gen. Stat. $\$ 52-89$ (1975). This requirement encompasses all "[m]esne process in civil actions." Id. Divorce complaints were expressly brought within the purview of $\$ 52-89$ by a 1974 amendment to the Dissolution of Marriage Act. Id. $\$ 46-36$ (requiring that dissolutions be commenced with "the service and filing of a complaint as in all other civil actions").

The chairman and vice-chairman of the Connecticut Bar Association's Family Law Section maintain that the amendment "is designed to reduce potential difficulties and dangers to the courts and the public in so-called 'do-it-yourself divorce." Schoonmaker \& Balbirer, Survey of 1974 Developments in Connecticut Family Law, 49 CoNN. B.J. 1, 4 (1975). If so, the "protective" measure is singularly arbitrary and meaningless; no Connecticut statutory or judicial provision ascribes any probative implications to the signature. Requiring its presence unnecessarily burdens self-representation, which is expressly excluded from the unauthorized practice prohibition set forth in CoNN. GEN. STAT. $\$ 51.88$ (1975).

This impediment to pro se divorce actions has recently been vitiated by the state judiciary's modification of its procedural rules. Effcctive October 1, 1976, an amendment to the Connecticut Practice Book directs superior court clerks to sign pro se complaints "unless [they are] defective as to form." ConNecricut Practice Book $\$ 28$ (1976).

86. Six of these plaintiffs were able to cajole initially recalcitrant superior court clerks into signing. The other seven met with obdurate denials. Five ultimately secured the signature of a sympathetic lawyer, and two signed their own writs. Future pro se plaintiffs should be spared such difficulties, given a recent amendment to the rules of practice which requires clerks to sign nondefective pro se complaints. See note 85 supra.

87. Conn. Gen. Stat. \$ 46-36 (1975).

88. See p. 108 infra. Eleven percent of the lawyer-initiated files revealed use of such alternative service.

89. See Connecticut Practice Book $\$ 394$ (1975). A copy of Form JD(COLP)-6002 is included in Appendix 6.

90. The Connecticut Dissolution of Marriage Act requires that one party to the divorce be "a resident of this state for at least the twelve months . . . next preceding the date of the decree," unless "onc of the parties was domiciled in this state at the time of the marriage" and has returned "with the intention of permanently remaining." CoNN. GeN. Stat. \$ $46-35$ (1975). 
box opposite each assertion. Provided that no cross-complaint has been filed and the defendant has waived 10-days notice of the filing of Form JD(COLP)-6002, the case proceeds to trial. Pro se plaintiffs were significantly more prompt in filing claims for a hearing than even those lawyers representing parties seeking relatively simple dissolutions.91

If no counsel has appeared for him, the defendant can ease the judge's burden at the final hearing by entering a pro se appearance. A pro se appearance is effected by signing an Appearance Form (JD (COLP)-6000). Otherwise the judge, in conformity with the terms of the federal Soldiers and Sailors Relief Act, ${ }^{92}$ must make a finding that the defendant is not in the military services of the United States. The plaintiff makes this possible by signing an affidavit similar or identical to Form 396.25 of the Connecticut Practice Book Annotated, which attests the plaintiff's belief that the defendant is a civilian.

The judge's discretion relative to the granting of the "dissolution" is limited, since a decree must enter on either party's uncorroborated testimony that the marriage has broken down irretrievably, provided that the husband and wife have signed a stipulation to that effect. ${ }^{.3}$ In contrast to the pro se files, $86 \%$ of which included such affidavits, only one-third ${ }^{94}$ of the lawyer-initiated files in the sample contained a stipulation of breakdown. ${ }^{95}$ Its absence leaves the judge the option either to deny the dissolution or to demand corroboration by witnesses who are not parties. But the former is almost unheard of in uncontested cases, ${ }^{96}$ and the infrequent reliance upon testimony of non-

91. Since 30 of the 31 pro se divorces involved no support or property awards, sce note 232 infra, only the 124 lawyer-initiated filcs with comparably limited decrees were used for time comparisons. Nonctheless, $61.3 \%$ of the pro se plaintiffs filed their claim for hearing within 120 days of the complaint, compared to $27.4 \%$ of the lawyers represcnting similarly situated plaintiffs.

Three pro se claims $(9.7 \%$ ) and 48 lawyer-initiated claims $(38.7 \%)$ followed the filing of the complaint by more than 150 days. Serenteen lawyer-initiated cases $(13.7 \%)$ were not claimed until over 300 days had clapsed; no pro se file indicated a like delay. The contrast in promptness of filing between lawyers and pro se plaintiffs is statistically significant at the .001 level.

92. 50 U.S.C. app. $\$ 520(1970)$.

93. Conn. Gen. Stit. $\$ 46-48$ (a) (1975). A similar standard is set forth in $\$ 305$ of the revised Uniform Marriage and Divorce Act. See note 13 supra. Even for states without such provisions in their no-fault divorce statutes, decrees are almost never denicd. A 1973 study of 20 no-fault divorce jurisdictions concluded that the no-fault system had the effect of making divorce "available upon unilateral demand." Foster \& Freed, Divorce Reform: Brakes on Breakdown, 13 J. FAx. L. 443, 446 (1973). See Glendon, Marriage and the State: The I'ithering Away of Marriage, 62 VA. L. REv. 663, 704-05 (1976).

94. 123/329 (base is less than 331 due to exclusion of two files for which data were inadvertently omitted).

95. And one of these was signed only by the attorneys for the parties, contrary to Conn. Gen. Stat. $\$ 46-48$ (a) (1975).

96. Of 830 uncontested dissolutions heard in New Haven during the period studied for the Project, there were no decree denials noted in the court calendar records. The 
parties is illustrated by the fact that more than half of the lawyerinitiated files contained neither a stipulation nor a list of available witnesses. ${ }^{97}$

Following the hearing, the plaintiff or his lawyer must complete and submit three copies of a decree form, using either Form JDSR214 (if the defendant did not file an appearance) or Form JDSR-213 (if he did). ${ }^{98}$ Blanks are provided for the nature of the award approved at the hearing and the name of the presiding judge. The lawyerinitiated sample produced two decrees with the wrong name affixed. In both instances, the incorrectly identified judge cured these defects by signing the document, despite the fact that he had not heard the case.

This progression exhausts the form preparation responsibilities of an attorney or pro se plaintiff in all cases involving neither minor children, a financial award, or an out-of-state plaintiff.99 And these three complicating considerations add only incrementally to the number of standardized documents required. If there are minor children, an affidavit must be filed "averring that there is no proceeding pending in any other court affecting the custody of such children." 100 As with most dissolution papers, a standardized form plus a signature effects compliance. ${ }^{101}$ This requirement went unmet in $26 \%$ of the New Haven lawyer-initiated divorces involving children, ${ }^{102}$ and $56.5 \%$ of the Bridgeport cases ${ }^{103}$ ignored it. ${ }^{104}$

two legal aid attorneys interviewed for the Project, drawing upon three years of highvolume divorce practice, could recall only one uncontested divorce which had been denied in either of their presences. Telephone Interview with David Snyder, supra note 53; Telephone Interview with Mary Keller, former New Haven Legal Assistance attorney (Jan. 30, 1976) (notes on file with Yale Law Journal). In that single instance, the anomalous judge was later persuaded by the (private) attorneys for the partics to let the case go off the calendar for that day instead of recording the denial, so that they could reclaim it later before a different judge. $I d$.

97. Sixty-three percent (206/329) of the lawyer-initiated files lacked stipulations, and of these, only $16.5 \%$ contained lists of witnesses. (Base is less than 331 due to the exclusion of two files for which data were inadvertently omitted.)

98. See Connecticut Practice Book $\$ 374$ (1975). The cited forms appear in the Practice Book as Forms 490 and $490 \mathrm{~A}$.

99. To facilitate recordkeeping, Connecticut imposes the additional minor requirement that all divorce parties or their attorneys supply certain basic demographic information on standardized Form VS-63. CoNN. GEN. STAT. $\$ 46-64$ (1975).

100. Connecticut Practice Book $\$ 394$ B (1975).

101. E.g., Connecticut Practice Book AnN. Form 396.9 (Supp. 1975). See Appendix 6.

102. There were 76 cases involving minor children in the New Haven lawyer-initiated sample.

103. There were 85 cases involving minor children in the Bridgeport lawyer-initiated sample.

104. This apparent ignorance of the rules of practice may be attributable in part to the recent origin of ConNecticut Pracrice Book $\$ 394 B$ (1975), which took effect on Oct. 1, 1974. But divorce kits have been criticized and sometimes banned in part because of an ostensible concern that changes in procedural law might result in errors by users 
For actions in which either party desires an award of "alimony, support, or counsel fees," a sworn statement "substantially in accord with Form $379 \mathrm{~A}$ " must be filed by "every party who has appeared." 105 Form $379 \mathrm{~A}$ is a two-page summary of current income, assets, expenses, and liabilities which is considerably less intimidating than the Internal Revenue Service's 1040 Form. ${ }^{106}$ As to the final "complicating" factor, an out-of-state spouse, the sole addition to the dissolution portfolio is one of two sets of standardized forms effecting service by registered mail, if the defendant's address is known, or service by publication, if his whereabouts are uncertain. ${ }^{107}$

In sum, it is highly doubtful that either judicial administration or public welfare considerations justify prohibition of lay advice or clerical help in the preparation of the "legal instruments" required in uncontested dissolutions. Lay specialists and plaintiffs using published kits may, like the sampled lawyers, make occasional errors. But corrections are easily effected, and opportunities for truly damaging mishaps are virtually nonexistent. ${ }^{108}$ Where the parties agree on custody, finances, and the necessity for a divorce, guidance concerning procedural formalities need not be the exclusive province of lawyers.

Nor does the presence of an attorney appear necessary at the single brief hearing required for an uncontested dissolution, Since grounds for the divorce can readily be established by the plaintiff's uncor-

of out-of-date kits. See Florida Bar v. Stupica, 300 So. 2d 683, 687 (Fla. 1974). It suffices to note that the lawyer monopoly is evidently not a reliable antidote. Moreover, the presence of such a high volume of mistakes in concluded files is a testament to the negligible significance of procedural errors. There is no indication that the missing affidavits were even noticed. And it is hardly conceivable that any judge would allow such an omission to influence his view of the equity of a proposed settlement.

105. Connecticut Practice Book $\$ 380$ (1975). Since nonappearing defendants are not required to complete the form, judges frequently approve awards with only the plaintiff's affidavit at hand. In $22 \%(39 / 178)$ of the cases in which alimony and/or child support awards of at least $\$ 5$ per week were made, the judge had only one (and in one case no) sworn affidavit to assist his determination of the fairness of the settlement presented.

106. Form $379 \mathrm{~A}$ is reproduced in Appendix 6.

107. The requisite Forms JDSR-909 and JDSR-906 are conveniently kept available for practitioners at all superior court clerks' offices, and are reprinted in Pro SE Dissolunon Group, supra note 68 , at $24-25$. Service by registered mail was successfully engineered by seven of the pro se plaintiffs in the sample. Service by publication entails a brief court hearing following the completion of the two forms.

108. In New Haven, for example, a defcctive pleading is mailed back to the attorney or pro se plaintiff filing it, with the type of error found checked off on a standardized form. See Appendix 6. For a description of the inconsequential burden placed upon court clerks by pro se plaintiff errors in Oregon, see Oregon State Bar v. Gilchrist, 538 P.2d 913, 917 (Or. App. 1975). See also note 104 supra.

Mitch Buszek, a spokesman for the California Divorce League's 21 lay assistance offices, stated in a 1976 interview that after three years of operations "we've never made a mistake we couldn't rectify. . . . If we make a mistake, and it's our fault, we pay legal expenses. We've never had to do this." Wall St. J., Sept. 3, 1976, at 1, col. 1, and 5, col. 2. 
roborated testimony, there is little need for courtroom finesse. Notably, the average duration of hearings timed by the authors in Bridgeport and New Haven was four minutes. ${ }^{109}$ Cases in which no financial awards were made usually required less than three minutes, while cases featuring such awards typically lasted about $51 / 2$ minutes. Five pro se divorce hearings consumed a total of 13 minutes. In these limited intervals little transpired beyond a brief review of the facts set forth in the complaint and the cause of the marital breakdown. If there was a support or property award, plaintiffs were sometimes queried by the judge as to whether they were satisfied with it.

\section{Ancillary Legal Issues}

Opponents of lay divorce establishments frequently assert that, form processing aside, there are important legal considerations inherent in most divorces which require a lawyer's attention:

In most instances, the basic need [for an attorney] is there. Court procedures can and should be simplified, but the complicated questions of divorce have always centered around issues of property and parental responsibility. ${ }^{110}$

The Florida Supreme Court's decision to prohibit published form processing advice emphasized that "dissolution of marriage covers a wide range of subjects, including contract and property rights of the parties, custody of children, inheritance, alimony, separate property." 111 Other commentators maintain that "virtually all divorces have some tax implications"112 and that simplified formal requirements are "only the tip of the iceberg in divorce proceedings .... [T] he basic problems are much more complex."113

As policy arguments for protecting the public against lay form processing assistance, these assertions are flawed in two respects. First, in many jurisdictions laymen with businesses unrelated to do-it-your-

109. These averages are computed from 35 hearings timed in Bridgeport and New Haven before three different judges. Eighteen of the cases $(51 \%)$ involved property or support awards. Five plaintiffs represented themselves. In licu of responding to attorney queries as to their age, date and place of marriage, and grounds for divorce, they read their testimony from prepared notes.

110. M. WHEFLLR, supra note 16, at 129. For other recitals of complications potentially imperiling pro se divorce litigants, see Marine, Do-It-Yourself Divorce-WisconsinUpdate, 38 UNaUth. Pric. News 131, 132 (1974), and an unauthorized practice complaint filed in Colorado Bar Ass'n v, Bratt, Cir. No. C50833 (Dist. Ct. Denver, Colo., filed Dec. 14, 1974), reprinted in Colorado Bar Association Starts Suit Against Lay Divorce Specialists, 39 Unauth. Pric. News 87, 89-90 (1975).

111. Florida Bar v. Stupica, 300 So. 2d 683, 687 (Fla. 1974).

112. Meeker, supra note 63, at 219.

113. Resh, supra note 77, at 23. 
self divorce have long been permitted to give advice concerning many of the financial and parental issues cited above. ${ }^{114}$ Second, any pro se plaintiff desiring a lawyer's expertise concerning such questions can readily secure it at prevailing hourly rates. ${ }^{115}$ Lay form processing does not preclude consultation with a lawyer. Rather, it leaves parties with the option to secure attorney advice priced at a fraction of the cost attending a lawyer's orchestration of the entire dissolution process. ${ }^{116}$

Conceivably, however, the prohibition of lay assistance could be defended as a device to force all divorcing parties to secure the benefits of legal consultation regarding financial and parental matters. The Project's data suggest that the actual attorney contributions to ancillary legal issues are too infrequent and insubstantial to support such a justification for the form-processing monopoly. This conclusion is supported below with a presentation of divorce file and client interview data, organized to elucidate both the contours of the financial/ parental settlements reached in the sampled actions and the magnitude of attorney contributions to these dispositions. ${ }^{117}$ Data regarding the content of settlements were obtained from the decrees and separation agreements in the surveyed lawyer-initiated files.

\section{a. Divorce Decrees}

Following a dissolution hearing, the plaintiff or his attorney submits a decree for ratification by the presiding judge. ${ }^{118}$ This document functions not only as the official order dissolving the marriage, but also as a vehicle for the formal allocation of financial and parental rights between the parties. The terms of the decree are enforceable by

114. A number of these putatively legal tasks are now performed by laymen under the incidental services exemption, which is part of the unauthorized practice doctrine in many states. See p. 112 supra. Thus, real estate transfers pursuant to divorce can often be handled by realtors, and tax problems can be taken to accountants.

115. Three New Haven kit purchasers interviewed for the Project roluntecred that they had disposed of their houses with the help of realtors or attorncys before pursuing their divorces pro sc.

116. Ralph Nader reports attorney charges for superintending uncontested dissolutions of $\$ 250$ to orer $\$ 750$. Standard hourly fees range from $\$ 25-\$ 50$, for small firms and young attorneys, to $\$ 75-\$ 100$, for large firms and experienced attorneys. Ralph Nader Reports, supra note 20, at 36. See D. Williums \& P. BLAcK, supra note 31, at 2 ('If you believe there are or may be significant tax questions involved in your situation, consult a qualified tax accountant or an attorncy who is well versed in tax law, to go over your separation agrecment. The cost should be a fraction of an average divorce fee."); note 205 infra.

117. Ethical considerations precluded the use of the lawyer questionnaires to supplement file and interview data on specific divorce cases. ABA Code of Proflssion.lL Responsibility Canon 4 (1975).

118. Connecticut's decree form is described at p. 127 supra. 
contempt citation. ${ }^{119}$ Tables 1 and 2 summarize the content of the sampled decrees.

\section{TABLE 1}

Divorce Decrees in Lawyer-Initiated Cases: Financial Awards

\section{A. OVERVIEW $(\mathrm{n}=331)$}

Type of Award

1. No Property, Alimony, or

Child Support Award

2. Property Award Only

3. Alimony Award Only

4. Child Support Award Only

5. Award in Two Categories

6. Award in All Three Categories
Relative Frequency

$$
\begin{array}{r}
37.1 \% \\
6.0 \% \\
7.3 \% \\
8.5 \% \\
36.0 \% \\
5.1 \%
\end{array}
$$

"Included under the "property" rubric are judgment provisions allocating real property, personal property, or debts of the spouses.

"Alimony" includes both lump sum and periodic payments. Three judgments awarded both; in general, there was a strong preference for periodic payments.

B. DETAILED BREAKDOWN ( $\mathrm{n}=331)$

Type of Award

1. Property Award

a. Awards Mentioning Houses

b. Awards Mentioning Automobiles $(n=328)^{a}$

c. Awards Mentioning Both Houses and

Automobiles $(\mathrm{n}=328)^{\mathrm{a}}$

d. Awards Mentioning Debts $(n=328)^{2}$

2. Alimony Award

a. Lump Sum Alimony

1. $\$ 1-5000$

2. $\$ 5001+$

b. Periodic Alimony

1. $\$ 1 / y r(n=329)^{2}$

2. $\$ 5-50 / w k(n=329)^{\mathrm{a}}$

3. $\$ 51+/ w k(n=329)^{2}$

3. Child Support Award*

a. $\$ 25 / w k$ or less $(n=326)^{2}$

b. $\$ 26-50 / w k(n=326)^{2}$

c. $\$ 51+/ w k(n=326)^{a}$
Relative Frequency

$23.9 \%$

$18.0 \%$

$7.3 \%$

$4.6 \%$

$6.7 \%$

$42.3 \%$

$9.1 \%$

$6.9 \%$

$2.1 \%$

$34.1 \%$

$13.4 \%$

$15.8 \%$

$4.6 \%$

$42.9 \%$

$11.6 \%$

$16.3 \%$

$14.1 \%$

a Base is less than 331 due to the exclusion of files for which data were inadvertently omitted.

- Child support awards were included in the divorce decrees of 142 of the 161 cases involving minor children. (Base is less than 162 due to the exclusion of one file for which data were inadvertently omitted).

119. Connecticut's Dissolution of Marriage Act encourages use of the contempt remedy for decree violations by directing the award of court fees to successful petitioners. 


\title{
TABLE 2
}

\author{
Divorce Decrees in Lawyer-Initiated Cases Involving \\ Minor Children: Parental Rights and Obligations $(n=162)$
}

\section{Category}

1. Custody $(n=161)^{2}$
a. To Wife
b. To Husband
c. Joint

Relative Frequency

2. Visitation
a. Not Mentioned
b. Granted but not Detailed
$86.5 \%$
c. Detailed

$90.1 \%$

$5.6 \%$

$4.3 \%$

3. Education $(n=159)^{a}$
a. Not Mentioned
$89.9 \%$
b. Voluntary Payments
$3.1 \%$
c. Mandatory Payments
$6.9 \%$

4. Medical Insurance Coverage for Children $\quad 54.3 \%$

5. Life Insurance Coverage with Children as Beneficiaries $17.3 \%$

a Base is less than 162 due to the exclusion of files for which data were inadvertently omitted.

Certain of the categories merit elaboration. Notably, over one-third of the decrees contained no financial allocation of any kind. Periodic alimony awards, although fairly common, served mainly as a supplement to child support; it was granted in only $20(12.0 \%)$ of $167^{120}$ childless $^{121}$ dispositions. Seven of these orders were nominal $\$ 1$ per

Conn. Gen. Star. $\$ 46-56$ (1975). Elsewhere, the scope of the contempt sanction has been limited by some courts, due to concern about constitutional prohibitions against imprisonment for debt. See, e.g., Bradley v. Superior Court, 48 Cal. 2d 509, 522, 310 P.2d 634, 642 (1957) (Adjustment of property interests "should be held to fall within the [state] constitutional proscription against imprisonment for debt."); Corbin v. Etheridge, 296 So. 2d 59 (Fla. 1973) (nortgage payment mandated in decree constitutes debt, and sanction of imprisonment therefore not available). However, the Reporter for the Committee on Uniform Marriage and Divorce Laws maintains that such constructions are "neither persuasive nor widely enough accepted to override the acknowledged utility of the contempt weapon," and he concludes that "the ability to enforce the financial aspects of divorce decrees by means of the contempt citation is vital to the recipient spouse." $R$. LEvY, supra note 5 , at 171 .

120. Base is less than 169 due to the exclusion of two files for which data were inadvertently omitted.

121. "Childless" divorces refer to those not involving minor children. The Connecticut Dissolution of Marriage Act contains no provisions relative to the rights and duties of parents toward children past the age of majority. See ConN. GEN. Stat. $\$ 46-42$ (1975). 
year allocations, ${ }^{222}$ and 11 went to women whose marriages were terminating after 20 years or more. Alimony and child support awards when present were generally modest. Property provisions were present in less than one-quarter of the decrees and dealt principally with houses and automobiles. ${ }^{123}$ There were virtually no references to divisions of personal property. ${ }^{124}$

Table 2 indicates the extent to which the decrees in lawyer-initiated actions delineated parental rights and obligations. With a few insignificant exceptions, it was possible to subsume all references to parental matters under one of the table's five categories. ${ }^{125}$ As can be seen, few judgments went much beyond allocation of custody and a general reference to visitation in their treatment of parental interests. Visitation rights of the noncustodial spouse were detailed in a small minority of cases. For the rest, the phrases "reasonable rights of visitation" and, occasionally, "liberal rights of visitation" constituted the sole contribution made by the decree to laying a foundation for future parent-child interaction. ${ }^{126}$ Intermittently, the reasonable or liberal rights were tempered by the admonition that the visitor could exercise them only if "sober." Education was for the most part left untreated, and one-third of the handful of judgments which did mention the subject committed the husband to contribute funds "if he deems it within his financial ability to do so."127 Less than one-fifth of the judgments mentioned life insurance. ${ }^{128}$ Maintenance of existing medical insurance policies covering minor children was directed in slightly over half the cases involving children; no judgment mandated that new or expanded coverage be secured.

122. The one-dollar-per-year awards are not without utility, since like any other order for periodic alimony payments they may be modified "at any time . . . upon a showing of a substantial change in the circumstances of either party." Id. $\$ 46-54$. Modification is precluded only if the decree so provides. $I d$.

123. Only $28 . \%(22 / 76)$ of the property provisions contained a reference to debts. (Base is less than 79 due to the exclusion of three files with property provisions for which content summaries were inadvertently omitted.)

124. Except for automobiles (mentioned in $31.6 \%(24 / 76)$ of the property awards), and in one case a horse, personal property was uniformly ignored in the decrees. (Base is less than 79 due to the exclusion of three files with property provisions for which content summaries were inadvertently omitted.)

125. Three decrees incorporating unconventional separation agreement provisions dealing with children are described in note 138 infra.

126. One decree provided an equally unilluminating alternative wording: "week night visitation upon agreement of the parties."

127. These provisions constitute the "voluntary payments" category listed under "Education" in Table 2 supra.

128. One such provision required the husband to maintain life insurance coverage for his children as long as he was employed by a company at which "he is entitled to free life insurance." 


\section{b. Separation Agreements}

The judicial decree need not be the only divorce document that treats the ancillary matters discussed above. The parties may also execute a contract, or "separation agreement," which can be employed to govern their relationship prior to the rendering of the decree and to allocate financial and parental rights in greater detail than the judicial orders described in the preceding section. ${ }^{129}$ Such agreements are binding upon the signatories (subject to the possibility of judicial nullification ${ }^{130}$ ), but are not necessarily enforceable by contempt citation..$^{131}$

Judging from the files sampled for the Project, separation agreements do not reflect a major attorney contribution to the dissolution process. Such agreements were filed in only $27 \%$ of the lawyer-initiated actions. ${ }^{132}$ Their substantive provisions usually served only as templates for clauses in the decrees that followed soon after. Connecticut's Dissolution of Marriage Act directs judges to incorporate in the decree all separation agreement provisions "concerning the custody, care, education, visitation, maintenance or support of any . . . children or concerning alimony or the disposition of property" that are found to be "fair and equitable."133 While most of the sampled agreements set

129. Of course, decrees for cases wherein detailed separation agreements have been filed usually incorporate many or all of the contract provisions. See pp. 134-35 infra.

130. See Conn. Gen. Stat. \$ $46-49$ (1975).

131. The contempt sanction is only available if the judge incorporates agrecment provisions in the decree of divorce. See R. Levr, supra note 5, at 196-98. For unincorporated provisions, the remedy for violations lies in "a separate contract action." Schoonmaker \& Balbirer, supra note 85, at 21.

132. There is some indication, however, that this figure understates the total number of agreements prepared. The superior court files for interviewed clients recorded a total of 35 separation agreements, yet 55 respondents reported having signed such agrcements. To be sure, some of the discrepancy may be attributable to clients confusing deeds or stipulations of irretrievable breakdown with separation agreements. Even so, the substantial disparity between file and interview accounts suggests that a number of agreements were executed but never made available for judicial scrutiny. Although the relevant Connecticut statute, CoNN. GEN. STAT. $\$ 46-49$ (1975), does not expressly requirc that agreements be filed, two prominent state family law specialists argue that "counsel are under a duty to advise the court of the existence of any "written agreement." McAnerney \& Schoonmaker, Connecticut's New Approach to Marriage Dissolution, 47 CoNn. B.J. 375,410 (1973).

Ethical considerations aside, failure to file deprives bencficiaries of the opportunity to secure incorporation of agreement provisions in the decrec. Incorporation creates the possibility of enforcement through contempt sanctions, see note 131 supra, and is a "prerequisite" to expedited interstate recognition of awards under the Uniform Enforcement of Forcign Judgments Act, which has been adopted by many states. See Schoonmaker \& Balbirer, supra note \$5, at 22 . Even if a judge declines to incorporate provisions in a separation agreement, he can confer formal "approval" upon them, foreclosing subsequent litigation alleging fraud, mistake, or undue influence. See Propper, The Judgment of Dissolution and the Agreement-Incorporation, Merger, Integration and Approval, 5i L.A.B.J. 177, 178 (1975).

133. Conn. GrN. Stat. $\$ 46-49$ (1975). 
forth support allocations, and more than half noted the consummation or imminence of real property transfers, ${ }^{134}$ all such references reappeared verbatim in the decree for the case. Moreover, agreements were not particularly useful as instruments for fixing obligations in the period preceding issuance of the decree, since a majority were signed 30 days or less before the final hearing. ${ }^{135}$

As to personal property and debts, areas left untreated by most decrees, ${ }^{130}$ more than half the separation agreements were effectively silent, as is illustrated in Table 3 below. The personal property provisions characterized in Table 3 as "pro forma" employed unilluminating language epitomized by the following quotations:

Each party shall own, free of any claim or right of the other, all of the items of property, real, personal, and mixed ... which are now owned by him or her....

Upon the execution of the written agreement, the husband and wife shall each become the sole owner of all personal property in their respective possession.

Even agreements classified in the "detailed treatment" category made frequent use of such unenlightening references as "a fair division of the pots and pans as agreed upon."

Regarding joint and individual debt obligations, Table 3 reveals that less than one separation agreement in five (involving $4.6 \%$ of the sampled divorces) provided for a specified division of outstanding family financial obligations. ${ }^{137}$ One-third of the agreements made no provision for debts, and almost half were classified as "pro forma" by virtue of their stylized announcement that there were no debts to divide.

134. Fifty-four percent $(44 / 81)$ of the separation agreements made reference to real property transfers. (Base is less than $\$ 9$ due to the exclusion of four files for which data were inadvertently omitted and to the failure of attorneys in four instances to submit full copies of separation agreements to the court.) Sixty-four percent of these provisions directed or recorded the consummation of a quitclaim transfer of one spouse's interest, while the remainder usually required a sale of the property and division of the proceeds. Where couples agree upon the disposition of their house, the necessary arrangements could be made through a real estate broker or a single consultation with an attorney.

135. Almost one-quarter of the agreements $(19 / 80)$ were signed within three days of the hearing. (Base is less than 89 due to the exclusion of five files for which data were inadiertenty omitted and to the failure of attorneys in four instances to submit full copics of separation agreements to the court.)

136. An entrenched judicial unwillingness to include personal property allocations in clecrees, described in Schoonmaker \& Balbirer, supra note 85 , at $20-21$, leaves a void which could to some extent be filled by separation agreements.

137. One of those so providing stated that the "husband will pay the wife adjust household bills." The relcrant sum was not affixed to the copy of the agreement filed with the court. 


\section{TABLE 3}

Treatment of Personal Property and Debt Allocations in Separation Agreements $(n=89)$

Type of Treatment

Relative Frequency

A. Detailed Division

1. Personal Property

$$
\begin{gathered}
34.5 \% \\
(n=84)^{2}
\end{gathered}
$$

2. Debts

$18.1 \%$ $(\mathrm{n}=83)^{\mathrm{a}}$

3. Both Personal Property and Debts* $6.0 \%$ $(\mathrm{n}=83)^{2}$

4. Either Personal Property or Debts* $47.0 \%$ $(\mathrm{n}=83)^{\mathrm{x}}$

B. Pro Forma Treatment

1. Personal Property $42.9 \%$ $(\mathrm{n}=84)^{\mathrm{a}}$

2. Debts

$$
\begin{gathered}
49.4 \% \\
(\mathrm{n}=83)^{\mathrm{a}}
\end{gathered}
$$

\section{No Mention}

1. Personal Property

$$
\begin{gathered}
22.6 \% \\
(\mathrm{n}=84)^{\mathrm{a}}
\end{gathered}
$$

2. Debts

* Of the cntire sample of lawyer-initiated files, $1.5 \%$ (5/325) contained separation agreements fixing a detailed division of both personal property and debts. Twelve percent $(39 / 325)$ of the lawyer-initiated files contained separation agreements making detailed provision for either personal property or debts. (Base is less than 391 due to the exclusion of files for which data were inadvertently omitted and to the failure of attorneys in four instances to submit full copies of separation agreements to the court.)

a Base is less than 89 due to the exclusion of files for which data were inadvertently omitted and to the failure of attorneys in four instances to submit full copies of separation agreements to the court.

In the area of parental rights, few separation agreements made contributions that were not fully replicated in the judicial decree for the case. ${ }^{138}$ Where agreements established detailed visitation rights, education-related responsibilities, or life insurance obligations, those provisions were almost uniformly incorporated in the succeeding

138. Among the rare nonredundant clauses were two pledges of summer camp expenditures "if summer camp is beneficial for the children," and one delegation of prospective disputes over a vaguely delineated joint custody award to the American Arbitration Association. 
decree. $^{139}$ Not redundant, but of questionable significance, were numerous boilerplate clauses pledging parents "not to hamper the free and natural development of the children's love and respect for the other party."

Most separation agreements consisted primarily of extended form clauses with such titles as Parties to Live Separate and Apart, No Molestation, No Duress, Absolute Waiver of Marital Rights, ${ }^{140}$ Nonmerger in Judgment, ${ }^{141}$ Law of Connecticut to Govern, and Paragraph Headings for Descriptive Purposes Only. ${ }^{142}$ These progressions of "legalese," as many interviewed clients characterized them, constitute at best a limited contribution to ancillary legal issues.

\section{c. Legal Advice Regarding Ancillary Issues}

The Project's client interviews indicate that attorney guidance did not play a major role in the shaping of the decrees and agreements

139. Connecticut law mandates incorporation of visitation and education provisions, provided that the judge deems them "fair and equitable." See p. 134 supra. The agreements sampled for the Project contained a total of 11 pledges for education-related payments and eight detailed visitation references, all of which were subsequently incorporated in the divorce decrees for the relevant cases. Nineteen of 23 life insurance provisions $(82.6 \%)$ were incorporated.

140. Many attorneys exhausted several double-spaced pages waiving "Marital Rights" which accrue only upon the death of a spouse and would disappear in any event once the dissolution was granted. See CoNN. GEN. STAT. \$ 46-12 (1975). Typical waivers were those of dower, thirds, curtesy, statutory allowance, widow's allowance, homestead rights, rights to take in intestacy, right to take against the will of the other, and right to act as administrator of the other's estate. These provisions would be meaningful only if the beneficiary of the waiver died during the interval between agreement execution and the decree. The median lapse between agreement and decree was less than 30 days. See $p$. 135 supra.

141. With the consent of the judge who presides at the dissolution hearing, a separation agreement providing for "merger" in the decree abandons its status as a contract and becomes enforceable through judgment remedies. An unmerged agreement remains, at least in thcory, an instrument independent of the decree, and its provisions can only be enforced by a contract action. Propper, supra note 132, at 177-78, 183. Since judgment remedies are generally swifter and less expensive than contract remedies, see note 132 supra, and since any agreement provisions regarding support and property are virtually certain to be carried over into the decree whether or not merger is expressly provided for, see pp. 134-35 supra, the utility of nonmerger clauses is unclear. One commentator has suggested that unmerged agreement provisions fixing alimony payments can be used to frustrate judicial modifications of the decree's alimony award, on the assumption that the contract can be sued on even after the decree has been changed. Propper, supra note 132, at $\mathbf{1 8 3}$. No cases are cited in support of this proposition, and at least one court has maintained that an unmerged agreement cannot "prevent later court modification of the [alimony] tcrms when need appears." McMains v. McMains, 15 N.Y.2d 283, 287, 206 N.E.2d 185, 188, 258 N.Y.S.2d 93, 97 (1965). In any case, the subterfuge is unnecessary in Connecticut and other jurisdictions which permit the parties to preclude alimony modifications by inserting appropriate language in the decree itself. CoNN. GeN. ST.ıT. $\$ 46-54$ (1975); Propper, supra note 132, at $183-84$.

142. One attorncy constructed a 17-page agreement out of such clauses for a couple with no children, no alimony payments, and no specified property or debts to divide. 
reviewed above. Over $60 \%{ }^{143}$ of the interviewed plaintiffs stated that they and their spouses had independently resolved all property, support, custody, and visitation issues; of these, only three indicated that they had restructured their agreements in response to lawyer suggestions. This low incidence of lawyer involvement is all the more striking because the interviewed client group had a higher percentage of decrees with financial awards than the lawyer-initiated sample as a whole and did not overrepresent childless couples. ${ }^{144}$

These findings strongly suggest that judicially acceptable awards can readily be crafted without legal assistance. This hypothesis is further supported by a review of statutory guidelines for alimony, child support, property, and custody in Connecticut and other no-fault jurisdictions. Cast for the most part in vague and conclusory language, these statutes provide no specific goal toward which divorcing couples must be steered. ${ }^{145}$ In Connecticut the judge presiding at a dissolution hearing is directed to approve the parties' oral or written agreement concerning financial or parental affairs if he finds it "fair and equitable under all the circumstances." ${ }^{146}$ Given the scope of this standard, it is to be expected that many divorce settlements could pass judicial muster without benefit of a lawyer's intervention.

Although attorneys are often not essential to the preparation of legally sufficient settlements, it might nonetheless be suggested that their presence ensures useful attention to issues that may be overlooked by the nonlawyer. Insofar as this argument rests upon the insertion of extra detail into decrees and separation agreements, it is unsupported by the data. Only $25.7 \%$ of the lawyer-initiated files contained decrees or agreements which included one or more of the following: (a) provision for life insurance; (b) detailed visitation rights; (c) imposition of responsibility for financing education of minor children; (d) detailed allocation of personal property; (e) detailed division of

143. 58/96 (base is less than 99 due to exclusion of cases in which no response was given).

Those client responses that did indicate some degree of attorney involvement are analyzed at pp. $144-45$ infra.

144. See Table B, note 62 supra.

145. E.g., N.J. Rev. STAT. $§ 2 A$ : 34-23 (Supp. 1975) (" $[T]$ he court may make such order as to the alimony or maintenance of the parties, and also as to the care, custody, education and maintenance of the children ... as the circumstances of the parties and the nature of the case shall render fit, reasonable, and just ...."); Vr. Stat. AnN. tit. 15, $\$ 292$ (1974) ("[T] the care, custody and maintenance of the minor children . . . .") Criteria in a number of other no-fault jurisdictions, frequently extending no further than a requirement that settlements be "just," are discussed in Foster \& Freed, Economic Effects of Divorce, 7 FAM. L.Q 275 (1973); and Zuckerman \& Fox, The Ferment in Divorce Legislation, $12 \mathrm{~J}$. FAM. L. 515, 565-71 (1973).

146. Conn. Gen. Stat. $§ 46-49$ (1975). 
debts. For parties whose divorces involved minor children, only $30.4 \%{ }^{147}$ of the relevant lawyer-initiated files indicated attention to any of these matters.

There remains one potential contribution, tax advice, the prevalence of which cannot be gauged from the divorce file data. ${ }^{148}$ As noted earlier, the lawyer's monopoly over form processing has sometimes been justified in part by the need to ensure that tax counsel is afforded to all divorcing parties. This argument presupposes that such information is customarily disseminated under the present structure; data from the client interviews undermine that assumption.

Interviewed clients were asked if their attorneys had provided advice on tax matters arising out of the divorce. ${ }^{149}$ Seventy-nine percent ${ }^{150}$ answered in the negative. ${ }^{151}$ Significantly, whether a plaintiff received tax advice did not correlate with whether his divorce had generated financial awards; $76.2 \%{ }^{152}$ of those in the latter category received no

147. $49 / 161$ (base is less than 162 due to exclusion of file for which a datum was inadvertently omitted).

148. The only relewant filc data are derived from separation agreements, $28.9 \%(24 / 83)$ of which made some reference to income tax matters. (Base is less than 89 due to the exclusion of two files for which data were inadvertently omitted and to the failure of attorneys in four instances to submit full copies of separation agreements to the court.) Typically the relevant contract terms provided for filing of joint income tax returns as long as the parties remained married, and in some cases the disposition of refund checks was settled. Several agreements allowed the husband to claim his children as deductions "if permissible under the U.S. Internal Revenue Code." Two pledged the spouses to file joint income tax returns "if legal," and another ordered the husband not to deduct his alimony payments and the wife not to declare them on their respective federal income tax returns. The latter arrangement would have been permissible only prior to the Revenue Act of 1942. See Young, Tax Problems Involved in Divorce, 1949 U. ILL. L.F. 670, 670-71 (1949). See generally I.R.C. $\$ \$ 71,215$.

149. Lawyers were not asked to estimate the percentage of uncontested cases in which they gave tax advice. However, only five attorneys volunteered tax counsel as one of the lawyer's most important divorce functions. See Table 4, p. 141 infra.

150. 76/96 (base is less than 99 due to exclusion of three interviews in which no response was given).

151. It could be argued that cven where no oral advice is given to clients, attorneys often craft financial settlements with significant tax considerations in mind. Although this possibility exists, it is troubling that explanations were so infrequently given, especially since apparently the one tax deductible portion of a divorce attorney's fee is his charge for tax advice. Meeker, supra note 63, at 239 (citing I.R.C. $\$ 212(3)$ and United States v. Davis, 370 U.S. 65 (1962)). And of course no such unarticulated assistance could have been extended to the many parties whose divorces involved no financial settlement. See Table 1, p. 131 supra.

Further, there is some evidence that lawyer manipulations of settlements for tax advantages were infrequent in the sampled actions. All but one of the lawyer-initiated cases which involved children and made provision for their maintenance earmarked a specific sum for "child support." Yet an arrangement which commingles child support and alimony in undifferentiated payments may frequently yield considerable nct $\operatorname{tax}$ savings to a divorced couple. See Basi \& Weinstein, supra note 63 , at $139-40$.

152. $48 / 63$ (base less than 65 due to exclusion of two interviews in which no response was given). 
advice. Also unadvised were $78.7 \%{ }^{153}$ of the plaintiffs with children. ${ }^{154}$ Six respondents volunteered that they had to consult accountants for needed information.

The Project's data on ancillary issues do not negate the possibility that lawyers can render useful contributions in many divorce proceedings. The results strongly suggest, however, that the form-processing monopoly protected by unauthorized practice doctrine is an expensive and unreliable means of ensuring that those contributions are made.

\section{Summary of Findings Relevant to Unauthorized Practice Doctrine}

A number of potential justifications for the lawyer's monopoly over divorce form processing have been considered. Clearly, professional expertise is not a prerequisite for the completion of dissolution forms. Discretion in form selection and preparation is minimal, and errors are either readily correctible or inconsequential. No aspect of these activities demands the safeguards of a fiduciary relationship. ${ }^{155}$ Nor is

153. $37 / 47$ (base less than 49 due to exclusion of two interviews in which no response was given).

154. Table $\mathrm{F}$ demonstrates that, according to the interviewed clients, neither children, home ownership, nor a joint annual income in excess of $\$ 15,000$ typically prompted tax advice. Only for those cases in which all three were present docs the proportion of clients receiving such advice exceed one-third.

\section{TABLE $\mathrm{F}$}

Tax Advice by Presence of Children, Houses, and/or Joint Annual Income in Excess of $\$ 15,000$

\section{Characteristic}

Children Involved $(\mathrm{n}=47)^{\mathrm{a}}$

No Children $(\mathrm{n}=47)^{\mathrm{b}}$

Home Owned $(\mathbf{n}=\mathbf{5 5})^{\mathrm{c}}$

No Home Owned $(n=40)^{a}$

Joint Income Greater than $\$ 15,000(n=36)^{\circ}$

Joint Income Less than $\$ 15,000(n=58)^{q}$

Children, Home, and Joint Income Greater than $\$ 15,000(n=13)$
Relative Frequency of Tax Advice

$21.3 \%$
$21.3 \%$
$32.7 \%$
$5.0 \%$
$33.3 \%$
$13.8 \%$
$53.8 \%$

Interviews in which no response was given to a particular question have been deleted from the computations, as indicated below:

${ }^{a}$ Base is less than 49 clue to the exclusion of two interviews.

b Base is less than 50 due to the exclusion of three interviews.

"Base is less than 56 due to the exclusion of one interview.

a Base is less than 43 due to the exclusion of three interviews.

- Base is less than 37 due to the exclusion of one interview.

Base is less than 60 due to the exclusion of two intervicws.

155. Fiduciary considerations constitute the lynchpin of judicial differentiations between published and personalized divorce assistance. See note $50 \mathrm{~s}^{*} \mathrm{pra}$. In vicw of the rudimentary nature of the "Iegal" documcnts prerequisite to an uncontested dissolution, there seems no reason to compel plaintiffs to pay for the establishment of a fiduciary relation if they do not desire onc. 
the character of uncontested hearings such as to necessitate an attorney's superintending presence.

Only if the lawyer monopoly serves some auxiliary purpose, transcending the document preparation with which unauthorized practice doctrine is nominally concerned, can the present limitations on pro se assistance be defended. Ancillary financial and parental issues cannot be cited to buttress the lawyer's procedural monopoly, absent evidence that the monopoly enhances useful legal dispositions of those issues. The Project data provide no such evidence. In any event, parties in need of legal advice on ancillary matters could usually reap substantial savings by consulting attorneys on these questions, while relying on kits or lay advisors for help with the formal requisites of an uncontested divorce.

\section{Negotiation and Personal Counseling}

In response to the Project questionnaire's inquiry regarding "the lawyer's most important functions in an uncontested divorce action," few attorneys adverted to any of the tasks emphasized in unauthorized practice opinions, such as form preparation, tax advice, and delineation of parental responsibilities. As Table 4 demonstrates, the contributions most frequently cited were negotiation and personal counseling. Since neither is solely within the province of attorneys, these activities have not figured prominently in the unauthorized practice controversy. Nevertheless, because of the high priority assigned to them by respondent attorneys, negotiation and personal counseling are analyzed in this section as potential policy reasons for preserving the lawyer monopoly.

\section{TABLE 4}

Functions Cited by Attorneys as "Most Important" in Uncontested Action $(\mathrm{n}=100)^{*}$

Function

Negotiation/Mediation

Personal Counseling

Form Preparation

Tax Advice

Defining Parental Rights

Drafting Separation Agreement
Relative Frequency

$$
\begin{array}{r}
65.0 \% \\
46.0 \% \\
13.0 \% \\
5.0 \% \\
2.0 \% \\
1.0 \%
\end{array}
$$

- Base is less than 106 due to the exclusion of questionnaires in which no response was given. 
Lawyers were also questioned as to the percentage of their uncontested divorces that "involved substantive disputes" requiring them "to negotiate an agreement" in the areas of alimony, child support, division of property, and custody/visitation. According to most respondents, negotiation over both support orders and property was necessary in more than $60 \%$ of their cases. ${ }^{156}$ Reported frequencies for custody and visitation disputes were much lower, although about onefifth of the lawyers stated that such problems arose in more than $40 \%$ of their uncontested actions. ${ }^{157}$

156. Table $G$ summarizes lawyer estimates of the percentage of their uncontested divorce cases requiring significant negotiation efforts. As is evident, reports by attorneys who handled more than 10 divorces for plaintiffs per year did not differ markedly from those for the sample as a whole.

\section{TABLE G}

Percentage of Uncontested Divorces Requiring Negotiations:

Lawyer Questionnaire Respondents

A. OVER PROPERTY

\section{$0-20 \%$}

$20-40 \%$

40-60\%

$60-80 \%$

80-100\%

B. OVER CHILD SUPPORT

\section{$0.20 \%$}

$20.40 \%$

$40-60 \%$

$60.80 \%$

$80-100 \%$

C. OVER ALIMONY

$\begin{array}{lr}0-20 \% & 1.9 \% \\ 20-40 \% & 12.4 \% \\ 40-60 \% & 14.3 \% \\ 60-80 \% & 36.2 \% \\ 80-100 \% & 35.2 \%\end{array}$

Attorneys Handling More than 10 Uncontested Divorces for

All Attorneys $(\mathrm{n}=106)^{\mathrm{a}}$ Plaintiffs per Year $(\mathrm{n}=55)$

D. OVER CUSTODY AND/OR VISITATION

$\begin{array}{lrr}0-20 \% & 43.4 \% & 30.9 \% \\ 20-40 \% & 37.7 \% & 43.6 \% \\ 40-60 \% & 12.3 \% & 16.4 \% \\ 60-80 \% & 4.7 \% & 5.5 \% \\ 80-100 \% & 1.9 \% & 3.6 \%\end{array}$

"For subcategories A, B, and C, base is 105 due to the exclusion of one questionnairc in which no response was given.

b Base is 54 due to exclusion of one questionnaire in which no response was given.

157. Sce note 156 supra. 
Not surprisingly, in light of these response patterns, most lawyers indicated that by far the most time-consuming aspects of their uncontested divorce practices were client conferences and negotiations. Attorneys were asked to estimate the average number of personal and phone contacts with their clients and the average amount of time spent negotiating with the defendant's lawyer. Almost half the respondents stated that in a typical uncontested case they had four or more personal conferences and seven or more telephone conversations with their client between the initial interview and the final hearing; the average negotiation estimate was in excess of four hours per action. Both client contact and negotiation estimates were even higher for lawyers reporting above average (for the sample) numbers of divorces involving children and disputes over property. ${ }^{1 \text { ss }}$

158. Forty-eight percent (47/99) of the lawyers reported more than three personal interviews and six phone conversations, on the average, with uncontested divorce plaintiffs. (Base is less than 106 due to the cxclusion of seven questionnaires in which no response was given.) Table $\mathrm{H}$ divides attorneys according to the percentage of their cases asserted to involve property disputes or children, and indicates the number of lawyers in cach group who stated that they typically exceeded the three personal, six phone contact level.

\section{TABLE $\mathrm{H}$}

Lawyer Estimates of Contact with Clients

\section{Lawyer's Descriplion of \\ His Divorce Practice}

$0.60 \%$ of Divorces Handled Involve

Children $(\mathbf{n}=30)^{\mathrm{s}}$

60-100\% of Divorces Handled Involve

Children $(\mathrm{n}=69)^{\mathrm{b}}$

$0.60 \%$ of Divorces Handled Require

Negotiations Over Property $(\mathrm{n}=37)^{\mathrm{c}}$

60.100\% of Divorces Handled Require

Negotiations Over Property $(n=62)^{d}$

\section{Percentage of Lawyers Reporling More Than Three Personal Contacts and More Than Six Phone Contacts}

$30.0 \%$

$$
55.1 \%
$$

$$
32.4 \%
$$

$54.8 \%$

a Base is less than 33 due to the exclusion of three questionnaires in which no response was given.

b Base is less than 73 due to the exclusion of four questionnaires in which no response was given.

c Base is less than 41 due to the exclusion of four questionnaires in which no response was given.

'Base is less than 64 due to the exclusion of two questionnaires in which no response was given.

Table I reveals a comparable distribution of responses with respect to negotiation time estimates. Lawyers reporting relatively high percentages of divorces involving children 
Client reports, however, are in sharp disagreement with the results tabulated from the lawyer questionnaires and indicate a relatively low level of attorney involvement in divorce negotiations. Although the interviewed clients had a higher proportion of substantial property and support awards than did the randomly sampled pool, ${ }^{150}$ they recalled far less difficulty in reaching agreement unassisted on settlements and far less contact with their attorneys than is suggested by the profiles derived from the lawyer questionnaires. Thus, whereas most lawyers reported having to negotiate substantive disputes concerning property in at least $60 \%$ of their cases, ${ }^{160}$ only $32 \%{ }^{101}$ of the interviewees indicated that their attorneys had played any appreciable role in determining property arrangements. Slightly over $40 \%{ }^{102}$ of the interviewed client group stated that they received assistance from

or significant property negotiations were disproportionately likely to exceed the fourhour average computed for the sample as a whole.

\section{TABLE I}

Lawyer Estimates of Time Spent, on the Average, Negotiating with Defendant's Attorney in Uncontested Cases

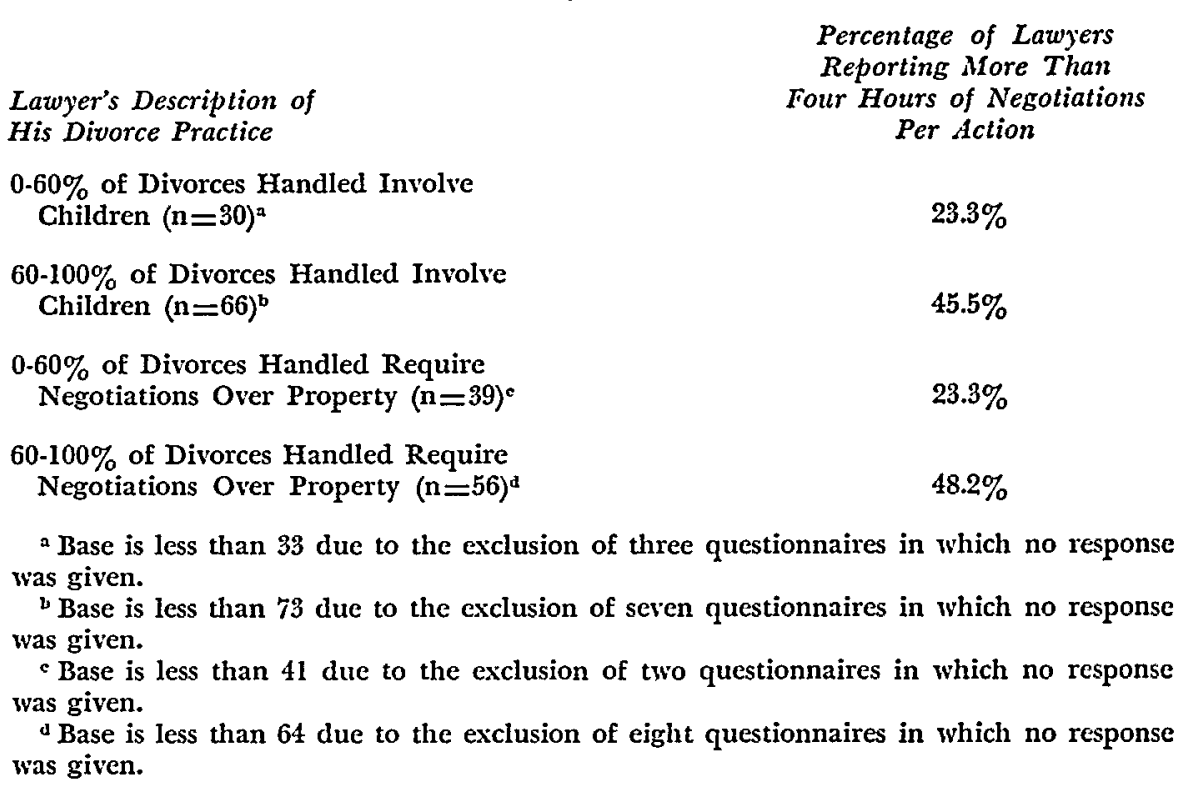

159. See note 62 supra.

160. See note 156 supra. Lawyers reporting relatively high uncontested divorce volumes tended to give slightly higher negotiation estimates. Id.

161. $31 / 98$ (base less than 99 due to exclusion of one interview in which no response was given).

162. $42 / 98$ (base less than 99 due to exclusion of one interview in which no response was given). 
their attorneys regarding either property, alimony, child support, custody, or visitation. However, in a number of instances aid was reported under circumstances in which no negotiations were conducted. ${ }^{103}$ Omission of this latter group left a total of $29 \%{ }^{164}$ of the divorces in the interviewed client sample which, according to client responses, may have involved disputes resolved by attorney negotiation.

Discrepancies are also evident in attorney and client estimates of contact with each other during the course of a dissolution. For purposes of comparison, phone and personal contact estimates were divided into two groups, with a respondent's classification depending upon whether he reported more than three of either type of contact. This dividing line split the client population into approximately equal subsets. No effort was made to assign comparative weights to phone and personal contacts. For both lawyers and clients, requested contact estimates covered the period between the initial interview and the final hearing. Table 5 shows the striking contrast between the perceptions of lawyers and clients. ${ }^{165}$

\section{TABLE 5}

Lawyer and Client Contact Estimates

0-3 Personal and

$$
\text { Lawyers }(\mathrm{n}=100)^{\mathrm{a}} \quad \text { Clients }(\mathrm{n}=92)^{\mathrm{b}}
$$

0-3 Phone Contacts

Reported

$$
4.0 \%
$$

4 or More Personal and/or 4 or More Phone

Contacts Reported

\footnotetext{
${ }^{a}$ Base is less than 106 due to the exclusion of questionnaires in which no response was given.

"Base is less than 99 due to the exclusion of intervicws in which no response was given.
}

163. Clients were asked whether thcy had reached agreement with their spouse concerning financial or parental matters without consulting an attorney (see Appendix 3, questions 3-5). Fourtecn respondents who answered in the negative voluntecred information which indicated that their lawyer had not been involved in negotiating the terms of dissolution. Generally there had been a substantial period of separation, during which a de facto settlement had evolved; the attorney simply formalized the existing arxangement.

164. 28/98 (base less than 99 due to cxclusion of one interview in which no response was given).

165. This disparity is statistically significant at the .001 level. The more detailed analysis of the data presented in Table $J$ reveals that the gap between lawyer and client perceptions narrows only for those plaintiffs whose interview responses contained some 
Thirty percent ${ }^{166}$ of the clients $\left(21 \%{ }^{107}\right.$ of those with children) recalled no personal conferences or only one conference with their lawyers.

Even if these client reports are regarded as less credible than the attorney estimates, contributions to the negotiation process cannot be invoked as justifications for the lawyer monopoly. Given the present contours of unauthorized practice doctrine, the potential value of mediation in uncontested actions does not provide a convincing basis for excluding laymen from all aspects of the divorce process. Divorce negotiations have never been construed as an exclusive prerogative of attorneys. In fact, many matrimonial courts rely on lay agencies to oversee negotiations in dissolution cases. ${ }^{168}$ While these agencies have

evidence of lawyer involvement in negotiations orer finances or children (sce p. 145 supra).

TABLE J

Lawyer and Client Contact Estimates: Client Subgroups

$\begin{array}{cccc} & & \text { Interviewed } & \text { Interviewed } \\ & & \text { Clients Whose } & \text { Clients Whose } \\ \text { Respondent } & \text { Interviewed } & \text { Decrees Con- } & \text { Lawyers As- } \\ \text { Lawyers } & \text { Child With } & \text { tained Property } & \text { sisted With } \\ (\mathrm{n}=100)^{\mathrm{a}} & (\mathrm{n}=47)^{\mathrm{b}} & \text { or Support } & \text { Negotiations } \\ & \text { Awards }(\mathrm{n}=59)^{\mathrm{c}} & (\mathrm{n}=26)^{4}\end{array}$

0-3 Personal and

0-3 Phone Contacts

Reported

$4.0 \%$

$40.4 \%$

$40.7 \%$

$23.1 \%$

4 or More Personal

and/or 4 or More

Phone Contacts

Reported

96.0\%

$59.6 \%$

$59.3 \%$

$76.9 \%$

a Base is less than 106 due to the exclusion of six questionnaires in which no response was given.

b Base is less than 49 due to the exclusion of two interviews in which no response was given.

- Base is less than 64 due to the exclusion of five interviews in which no response was given.

¿ Base is less than 28 duc to the exclusion of two interviews in which no response was given.

Moreover, although $47.5 \%$ (47/99) of the lawyers reported four or more personal contacts and seven or more phone conversations, on the arerage, per uncontested divorce, only $10.8 \%(10 / 92)$ of the client recollections were in this range. (Bases are less than 106 (for lawyers) and 99 (for clients) due to the exclusion of cases in which no response was given.)

166. $28 / 95$ (base less than 99 due to exclusion of four interviews in which no response was given).

167. $10 / 47$ (base less than 49 due to exclusion of two interviews in which no response was given).

168. Connecticut employs 38 lay domestic relations officers in nine offices attached to superior court divisions throughout the state. These offices received referrals of 1,764 
historically placed primary emphasis on reconciliation and resolution of custody/visitation issues, their utility in facilitating property and support settlements has been widely recognized. ${ }^{169}$

Although unauthorized practice doctrine does not restrict the negotiation function to lawyers, it might yet be maintained that they are uniquely suited to assume that role. ${ }^{170}$ From this assertion could flow an argument for banning pro se kits and services. If parties can obtain form preparation assistance only from an attorney, they will be more likely to rely on his guidance in resolving financial and parental disputes. It is, however, questionable whether a lawyer's special training renders him either an essential or effective negotiating agent in the divorce context.

As has already been noted, no-fault divorce statutes typically do not afford useful standards of fairness with regard to financial and parental issues. ${ }^{171}$ What is important in uncontested cases is that the parties arrive at a mutually acceptable agreement which will be satis-

contested matters in fiscal year 1974-75, categorized as follows: custody, 1,016; visitation, 384; finances, 131; vacate orders, 45; other, 188. F.MiLY REL.ITIONs Division, ConNecticut Supreior Court, ANNu.ti. Rerort Fiscil Y'cir 1974-1975 at 1, unnumbered p.22 (1975). In addition, the Division conducted 4,657 "court conferences" with "attorncys and litigants prior to hearing in an effort to resolve disputed issues through amicable agreement or to identify and focus the issues actually in dispute." Id. at 5 .

Connecticut's lay domestic relations officers are explicitly empowered to "attempt the reconciliation and adjustment of differences between the parties to dissolution of marriage and legal separation proceedings, particularly where there are minor children involved." Connecticur Prictice Book $\$ 398$ (c) (1975). In New Haven most contested dissolution matters are automatically referred to the local Domestic Relations Office. Interview with Bernard Christenson, Director of the New Haven Domestic Relations Office, in New Haven (Feb. 4, 1976) (notes on file with Yale Law Journal).

Such referrals are not unique to Connecticut. By 1965 at least $27 \%$ of all American divorce tribunals employed counseling personnel. J. QUENSTEDT \& C. WINKLER, What ARE Our Domestic Relations Judges Thinking?, unnumbered p.4 (ABA Family Law Section Monograph No. 1, July 1965). A 1971 study reported extensive use of lay conciliation and mediation adjuncts in 14 states. McLaughlin, Court-Connected Marriage Counselling and Divorce-the New York Experience, 11 J. FAM. L. 517, 517 (1971).

169. Maxine Virtue's 1956 study for the ABA's Interprofessional Commission on Marriage and Divorce Laws concluded that court marriage counseling services were useful in "reducing tension and conflict between spouses so that they can co-operate more efficiently with counsel and with the judge." M. VIRTUE, supra note 6, at 220. Accord, Foster, Conciliation and Counselling in the Courts in Family Law Cases, 41 N.Y.U. L. REv. 353, 381 (1966); Baum, A Trial Judge's Random Reflections on Divorce: The Sacial Problem and What Lawyers Can Do About It, 11 WaYNe L. REv. 451, 457 (1965). A recent conciliation program in the New York courts "had meager results in reconciling couples," but "did effective work in the conciliation of disputes as to ancillary matters such as alimony, child support, custody and visitation." Foster \& Freed, supra note 93, at 473. The report of the Committee on Uniform Marriage and Divorce Legislation adverted favorably to use of conferences with forensic social workers where "financial matters were in dispute or had not been settled." R. LEVY, supra note 5 at 116.

170. Cf. Q. Johnstone \& D. Horson, supra note 46, at $81-92$ (discussion of salience of negotiation activity in legal practice generally).

171. See p. 138 supra. 
factory to the court. To that end, their preeminent need is likely to be a delineation of the perimeters within which choice is possible, e.g., minimum and maximum child support figures likely to be acceptable to the presiding judge. For couples capable of reaching a consensus once informed of extant judicial norms, published guidelines could suffice. ${ }^{172}$

Moreover, relegating the initial perimeter-setting function to an attorney can be counterproductive in the divorce context, given his commitment under Canon 7 to "Represent a Client Zealously Within the Bounds of the Law."173 This Canon, with its accompanying directive to "resolve in favor of [the] client doubts as to the bounds of the

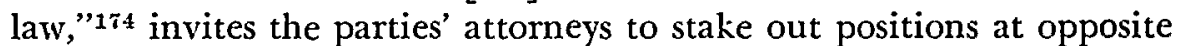
poles of the broad spectrum of permissible support and property allocations. ${ }^{175}$

Where this invitation is accepted, the long-term interests of the divorcing couple and their children are jeopardized. Unrealistic expectations may be instilled; parties represented by two advocates whose initial positions intersect at few or no points face an unnecessarily divisive bargaining process. ${ }^{176}$ Acrimonious interchanges may reduce the prospects for enduring adherence to the accords reached. So too, a "victory" for one party in negotiations may produce a skewed accom-

172. Sliding numerical scales, which gear recommended child support awards to payor income and family size, are proposed in Loucks, Explaining Divorce Proceedings to $a$ Client, 20 Prac. Law., Jan. 1974, at 83, 85; and Lamensdorf, A Guide for Pendente Lite Support, FaM. L. NewsletTER, Spring 1974, at 14, 14. For comments by judges on the utility of standardized, graduated guidelines for child support, see J. QueNSTEDT \& $C$. WINkLER, supra note 168 , at 2 . Such guidelines could, of course, be made public. California Divorce League (lay divorce assistance) offices refer clients to state welfare department estimates on the cost of child rearing. Telephone Interview with Ruth Ordesch, supra note 31 .

173. Aba Code of Professional Responsibility Canon 7 (1975).

174. Id. EC 7-3. In the same vein, note 10 to Canon 7 refers to ABA Opinion 314 (1965): "'A] lawyer who is asked to advise his client . . . may freely urge the statement of positions most favorable to his client just as long as there is a reasonable basis for those positions."

175. This temptation is recognized in Baum, supra note 169 , at 460 , and Freeman \& Weihofen, Client Counseling in Negotiating the Terms of A Divorce, 18 Pric. LAw., April 1972, at 41, 47. See R. FELDER, supra note 6, at 1-2 ("[O]nce I have been hired, ... my sole aim is to gain victory. And in doing so, I will do anything and everything I think necessary to serve the interests of my client ... to gain him a divorce in which he will come out financially, psychologically-in every way-on top.")

176. Thus, one interviewed client reported that a tentative agreement between the spouses was rejected by both their lawyers as too farorable to the other side; the outcome of extended bargaining was a settlement identical to that proposed initially.

The Kahn study drew upon an extensive matrimonial law practice for the following observation: "When two lawyers are pitted against each other and engaged in legal combat on behalf of their clients, matrimonial problems obviously are not being solved. Each lawyer, championing the cause of his client, only magnifies ill will . . . R. KAHN \& L. KAHN, supra note 7, at 73-74. 
modation which is unworkable in the long run. ${ }^{177}$ Since many provisions in divorce settlements, among them alimony, child support, and visitation, require cooperation over an extended interval, the adverse consequences of misplaced advocacy may prove substantial.

The lawyer questionnaires suggest that these dangers are too often unappreciated. When asked to characterize their most important functions in an uncontested divorce action, a sizeable minority of attorneys responded with statements comparable to the following:

To get the most money that you can for the wife and to save the husband as much as possible.

As counsel for the wife your job is to thrust, while a husband's counsel is basically a defensive maneuver.

Representing wife: getting money from husband. Representing husband: presenting hardship case.

Twenty-three percent ${ }^{178}$ of questionnaire respondents, and $32.7 \%{ }^{179}$ of those handling more than 10 divorces for plaintiffs per year, phrased their responses specifically in terms of advocacy of their client's position, as opposed to an eqaitable adjustment between the parties.

An additional impediment to effective mediation by attorneys is the high percentage of unrepresented defendants in uncontested divorce cases. Fifty-six percent of the defendants in the lawyerinitiated cases sampled for the Project did not retain counsel..$^{180}$ Table 6 reveals that many defendants were without legal representation even in cases involving children and financial awards.

177. As one lawyer wrote in a response to the Project questionnaire: "Unfair and/or burdensome arrangements will result in continuing disputes and unhappiness after judgment." Similar considerations moved Whecler to conclude that parties might be more likely to live up to an agreement reached in conference with a disinterested counselor than they would be if their settlement represented the result of a clash of advocates. $\mathbf{M}$. WheELcR, supra note 16 , at 108 .

178. $23 / 99$ (base less than 106 due to exclusion of seren questionnaires in which no response was given).

179. 17/52 (base less than 55 due to exclusion of three questionnaires in which no response was given).

180. Attorneys filed appearances on behalf of defendants in $41.8 \%(138 / 330)$ of the lawyer-initiated actions. (Base is less than 331 due to the exclusion of file for which a datum was inadvertently omitted.) In seren additional cases, although no appearance was entered, a separation agreement was filed which stated that the defendant had been represented in negotiations by a lawyer. The remaining 185 defendants in the sample $(50.1 \%)$ were classified as unrepresented, meaning that they had not retained an attorney at any point in the proceedings.

The accuracy of this method of determining lawycr involvement is confirmed by interview responses. Based on file data, one-half of the defendants in the interviewed client cases were placed in the "unrepresented" category. When asked if their spouses had retained an attorney, 98 of the 99 interviewed clients gave an answer in accord with the initial classifications. 


\section{TABLE 6}

\section{Unrepresented Defendants in Lawyer-Initiated Cases}

Category

Relative Frequency

All Cases $(\mathrm{n}=330)^{\mathrm{a}}$

Cases Involving Minor Children $(\mathrm{n}=160)^{\mathrm{b}}$

Cases Not Involving Minor Children $(n=168)^{c}$

$56.1 \%$

$51.3 \%$

$61.3 \%$

Cases Involving Financial Awards (Property,

Alimony, and/or Child Support) $(\mathrm{n}=199)^{\mathrm{d}}$

Cases Not Involving Financial Awards $(n=130)^{\circ}$

$44.2 \%$

$73.8 \%$

Inadvertent omission of data required the exclusion of files from certain computations, as indicated below:

a Base is less than 331 due to exclusion of one file.

base is less than 162 due to exclusion of two files.

- Base is less than 169 due to exclusion of one file.

d Base is less than 200 due to exclusion of one file.

- Base is less than 131 due to exclusion of one file.

These circumstances placed major ethical restraints upon plaintiffs' attorneys desiring to mediate between the parties. Disciplinary Rule 7-104 and Ethical Consideration 7-18 of the ABA Code of Professional Responsibility severely constrict the extent to which attorneys may deal directly with unrepresented "adversaries": any proffer of advice in the course of contact with such parties is explicitly proscribed.181 In conjunction with the Canon that "A Lawyer Should Avoid Even the Appearance of Professional Impropriety,"182 these strictures inhibit a lawyer's oversight of negotiations between his client and an unrepresented defendant spouse. ${ }^{183}$ This problem is widely recognized in the literature, ${ }^{184}$ one suggested response being the proctrement of

181. Ethical Consideration 7-18 requires that lawyers dealing with unrepresented parties "not undertake to give advice to the person . . except [to] advise him to obtain a lawyer:" ABA Code of Professionil Responsibility EC 7-18 (1975). Accord, id. DR 7-104.

182. Id. Canon 9.

183. To assess the impact of the ethical dilemma on lawyers' behavior in the surveyed counties, the Project's questionnaire asked attorneys for estimates of the amount of time spent negotiating, on the average, with unrepresented defendants. Only $43.4 \%$ (46/106) of the respondents indicated that they engaged in the practice at all; a majority of those who did typically spent an hour or less. Thus, unless the defendant hired a lawyer, most attorneys surveyed curtailed their role as negotiators.

EC 7-18 was discussed at the ABA's 1976 Annual Meeting, where a panclist in a symposium on family law practice indicated that he always refuses to talk with unrepresented defendants. 45 U.S.L.W. 2113 (Aug. 24, 1976).

184. See, e.g., Q. Johnstone \& D. Hopson, supra note 46, at 89 ; R. K.1HN \& L. K.1HN, supra note 7, at 129; Baum, supra note 169, at 460; Merder, The Necd for an Expanded Role for the Attoney in Divorce Counseling, 4 F.ı. L.Q. 280, 291 (1970); Philips, Mental Hygiene, Divorce, and the Law, 3 J. FAM. L. 63, 65 (1963). I'hyllis Eliasberg, a California lawyer who heads the Wave Project, a divorce counseling organization, advocates banning 
a defendant's signed acknowledgment that "you are his wife's attorney and are obliged to protect her interests, and you owe no duty to him." 185 Negotiations can then proceed, but they do so under conditions which are unlikely to enhance the probability of consensus or to promote adequate dissemination of information to both parties.

To be sure, there are cases which, although legally uncontested, nevertheless involve disputes so heated that both sides benefit by hiring lawyers to assert their interests. However, less than one-third of the actions involving the Project's interviewed clients could possibly be so characterized. ${ }^{180} \mathrm{~A}$ relatively infrequent eventuality cannot support the use of unauthorized practice doctrine to force all divorce plaintiffs to employ attorneys.

Thus, the primary constituents of an uncontested divorce practice

attorneys entirely from divorce proceedings because she believes their adversary role militates against conciliation between the two parties. Wall St. J., Sept. 3, 1976, at 1, col. 1.

185. Freeman \& Weihofen, supra note 175, at 42. See 45 U.S.L.W. 2113 (Aug. 24, 1976) (symposium panclist at $1976 \mathrm{ABA}$ Annual Meeting reports using similar warning when dealing with unrepresented defendants: "I have no obligation to look after your interests and I have no obligation to be fair to you.") It should be noted that the unrepresented defendant is not always male: $63 \%$ of the 103 defendant women in the lawyer-initiated sample did not retain attorneys.

186. Table $\mathrm{K}$ compares the minority of interviewed clients $(29 \%)$ who received some negotiation assistance with the rest of the interviewed sample. Attorney negotiations usually occurred in cases involving ancillary property and child-related matters. While these actions presented opportunities for legal contributions, it must be noted that lawyer aid was frequently expensive and brought little satisfaction to the recipients.

TABLE K

Characteristics of Interviewed Client Cases by Lawyer Involvement in Divorce Negotiations*

\begin{tabular}{|c|c|c|c|c|c|}
\hline & $\begin{array}{c}\text { Joint In- } \\
\text { come in } \\
\text { Excess of } \\
\$ 15,000 / y r .\end{array}$ & $\begin{array}{l}\text { House } \\
\text { Involved }\end{array}$ & $\begin{array}{l}\text { Children } \\
\text { Involved }\end{array}$ & $\begin{array}{l}\text { Fee in } \\
\text { Excess of } \\
\$ 950\end{array}$ & $\begin{array}{c}\text { Client Ex- } \\
\text { pressed } \\
\text { Dissatisfac- } \\
\text { tion with } \\
\text { Lawyer's } \\
\text { Handling } \\
\text { of Divorce * }\end{array}$ \\
\hline $\begin{array}{l}\text { Involvement Reported } \\
\quad(n=28)\end{array}$ & $46.4 \%$ & $78.6 \%$ & $71.4 \%$ & $\begin{array}{l}47.8 \% \\
(\mathrm{n}=23)^{\mathrm{a}}\end{array}$ & $64.3 \%$ \\
\hline $\begin{array}{l}\text { No Involvement Reported } \\
(n=70)\end{array}$ & $\begin{array}{c}3 \dot{x} .8 \% \\
(\mathrm{n}=69)^{\mathrm{b}}\end{array}$ & $48.6 \%$ & $41.4 \%$ & $\begin{array}{c}9.3 \% \\
(\mathrm{n}=54)^{\mathrm{b}}\end{array}$ & $24.3 \%$ \\
\hline
\end{tabular}

- With the exception of income, all the contrasts revealed in Table $\mathrm{K}$ are statistically significant at the .01 level. The income differential is not significant at the .05 level.

* Clients were not asked directly whether they were satisfied with their lawyer's performance. This categorization is based on responses to questions regarding, inter alia, fees, negotiations, and the general manner in which the client's case was handled.

" Base is less than 28 duc to the exclusion of interviews in which no response was given.

" Base is less than 70 duc to the exclusion of interviews in which no response was given. 
appear to be elementary formalities, ancillary advisory functions irregularly exercised, and episodic mediation problems that can be exacerbated by legal representation. To these characteristics must be added a final, human dimension.

In defining their most important divorce functions, attorneys who completed the Project questionnaire placed emotional support and personal counseling second in priority only to the negotiation of disputes. ${ }^{187}$ Almost one-half of the lawyers adverted to matters subsumed by one respondent under the following expansive labels: "Acting as psychologist, father-figure, confidant, and psychiatrist."18s

Arguably, these characterizations suggest reasons to reconsider rather than retain the lawyer monopoly over form processing in divorce actions. For, as numerous commentators have observed, legal training does not provide adequate preparation for personal counseling. ${ }^{180}$ Divorcing parties may experience psychological and emotional dislocations ${ }^{190}$ which will not readily dissipate upon application of the amateurish advice with which the family law literature is replete. ${ }^{101}$

187. See Table 4, p. 141 supra.

188. For similar characterizations of the divorce lawyer's role, see R. Frroer, supra note 6, at 62-63; H. O'Gorman, supra note 11, at 107; and Spellman, How Should the Adequacy of Compensation for the W'ife's Attorney in Divorce Cases Be Determined?, 4 FAM. L.Q. 53, 56 (1970).

189. See Alexander, Public Service by Lawyers in the Field of Divorce, 13 Ono Sr. L.J. 13, 19 (1952); Baum, supra note 169, at 464-65; Bellinson, Changing Dynamics in Attorney-Client Relationship Due to No-Fault Divorce Legislation, FAM. L. Newslettrr, June, 1973, at 5, 6-7. One commentator has urged that all counseling functions be performed by qualified laymen, in a move to "free the lawyer from his present role as an amateur family therapist and allow him to devote himself to the legal aspects of family dissolution." Kay, A Family Court: The California Proposal, 56 CaLIF. L. REv. 1205, 1211 (1968).

Those few lawyers who possess degrecs in psychology or counseling are prohibited by $A B A$ regulations from stating the fact on their professional cards. See ABA CodE of Professional: Responsibil.ITy DR 2-102(E) (1970); ABA Comm. on Ethics ANd Grifvances, INFORMAL OpINION No. 1248 (1972). Cf. id. No. 1049 (1968) (practicing lawyer may not be listed in classified section of the telephone directory under "Marriage and Family Counselors" if also listed under "Lawyers").

190. W. Goode, supra note 59, at 186-87; M. HUNt, The World of The FormerLy Married 27-31 (1966); N. KohUt, supra note 59, at 50-51; H. O'GorMaN, supra note 11, at $82-92$.

191. For example, a 1963 seminar for divorce lawyers produced the assertion by one panelist that women who complain about their spouse's brutality or alcoholism "[g]en. crally ... want only the lawyer's sympathy and never complete the [divorce] proceedings." Barnett, Emotional Problems Encountered in Divorce Cases-A Seminar, 3 J. Fus. L. 208, 211 (1963). Seminar participants were further advised to handle "obstinate" clients who "argue" and "won't follow advice" by threatening to withdraw from the case, since "most women clients will accede under this threat." Id. at 218.

Another writer urges lawyers to handle demands posed by emotionally disturbed clients by announcing that all phone calls will be individually billed at substantial rates: "[s] uch handling can have a good therapeutic effect on the client." Usdin, Marital Problems and the Attorney, 12 LOY. L. REv. 9, 12 (1965). Divorce lawyers have been 
However, the present lawyer monopoly over form processing renders attorneys the first and often the only source of aid with such problems. ${ }^{192}$

Of special concern in this context are certain findings of the Project regarding interviewed clients whose divorces may have involved significant spousal conflict. ${ }^{193}$ Sixty-five percent ${ }^{104}$ of these plaintiffs received no counseling from sources other than a lawyer throughout the pendency of their divorce proceedings. ${ }^{195}$ Yet $57.7 \%^{196}$ were concluding a marriage of more than 10 -years duration, $71.4 \%$ had minor children, $82.1 \%$ were female, and $82.1 \%$ had undergone less than six months of separation from their spouses at the time of filing $(57.1 \%$ had not yet separated). However well-intentioned, the attorneys serving these clients were clearly not an optimal source of therapy. Removing the necessity of hiring a lawyer to prepare divorce papers might perform the salutary function of diverting more couples to qualified counselors, ${ }^{197}$ while leaving those desiring attorney guidance free to obtain it.

\section{The Costs of the Lawyer Monopoly}

The most obvious cost of the lawyer's divorce processing monopoly is the financial burden imposed on those who must purchase legal services. As Table 7 demonstrates, $88.4 \%$ of the clients interviewed paid at least $\$ 500$ for their divorces; $38.4 \%$ were charged more than $\$ 750$. Nine pro se plaintiffs volunteered that they had been quoted

advised to generate sex counseling insights from "self-perception," $i d$. at 10, and to rely on their "intuitive understanding of human nature" when confronted with psychological instability, Merder, supra note 184 , at 288.

192. Divorce lawyers seldom refer clients to lay counseling professionals. $N$. KoHur, supra note 59, at 95-96 (citing sources). Only one of the Project's 106 completed attorney questionnaires mentioned such referrals as one of the lawyer's most important functions. Cf. Merder, supra note 184, at 29.4 (discussing laws in Canada, England, and Australia that require attorneys to provide all divorce clients with list of marriage counselors).

193. The 28 clients so classified were the $29 \%$ who indicated that they had received attorncy assistance in negotiating the terms of parental and/or financial settlements. See p. 145 supra.

194. 17/26 (base less than 28 due to exclusion of two interviews in which no response was given).

195. As to the rest of the intervicwed clients, the percentage recciving no counseling, $690 \%(47 / 68)$, was only slightly greater. (Base is less than 70 due to the exclusion of two interviews in which no response was given.)

196. 15/26 (base less than 28 due to exclusion of two interviews in which no response was given).

197. If partics necd not employ a lawyer to initiate divorce proceedings, they may be less inclined to seek attorney advice on personal problems. Presumably, too, the availability of inexpensive form preparation assistance would release resources with which couples could secure professional counseling services. 


\section{TABLE 7}

\section{Reports by Interviewed Clients of Fee Charged by Their Attorneys $(n=78)^{2}$}

Fee Range

$\$ 250$ or less

$\$ 251-499$

$\$ 500-750$

$\$ 751-999$

$\$ 1000$ or more
Relative Frequency

$$
\begin{array}{r}
2.6 \% \\
9.0 \% \\
50.0 \% \\
17.9 \% \\
20.5 \%
\end{array}
$$

3 Base is less than 99 due to the exclusion of cases in which no response was given. This question elicited by far the lowest response rate of any on the interview form. It does not appear likely that low fees were disproportionately concealed, however, since the response rate was higher for parties whose divorces involved no support or property awards $(79.4 \%)$ than for clients who underwent more complex divorces $(76.9 \%)$.

prices averaging $\$ 750$ for divorces they ultimately obtained themselves with the aid of the four-dollar Pro Se Dissolution Kit. ${ }^{108}$

Even those clients whose dissolutions were unencumbered by property or child support awards paid $\$ 500$ or more in $77.8 \% 109$ of the cases. In none of these cases did the clients report lawyer invodvement in any divorce negotiations, and for the most part they had little contact with their attorneys. ${ }^{200}$ In effect, they were paying substantial sums for representation at a hearing and three completed forms: a complaint, claim for a hearing, and decree. ${ }^{201}$ Lawyers responding to the Project questionnaire reported needing a little under one hour, on the average, to prepare these forms. Most of these attorneys indicated that they spent an additional hour or less on the initial client interview, plus approximately an hour and a half waiting in court for

198. In addition to the kit price, pro se plaintiffs (and their lawyer-assisted counterparts) were required to pay a $\$ 45$ filing fee, ConN. GEN. STAT. \$ 52-259 (1975), and the sheriff's charge for serving the complaint, $i d$. $\$ 52-261 ;$ p. 125 supra. Indigents can apply for a waiver of these fecs. See note 213 infra.

199. 21/27 (base less than 34 due to exclusion of seven interviews in which no response was given).

200. Fourteen of the 34 interviewed plaintiffs whose divorces did not involve financial awards stated that they saw their lawyers in person once or not at all between the initial interview and the final hearing. Only four of these plaintiffs reported more than three personal conferences.

201. One plaintiff, separated from her husband for two years and no longer sure of his whereabouts, was charged $\$ 900$ (and felt it was a fair fee because "I work for a lawyer who charges more"); a woman whose six-year separation had been preceded by only three months of cohabitation was billed \$850; and an elderly couple whose antenuptial agreement settled all property matters paid $\$ 900$. Another couple with joint fees totaling $\$ 1,750$ was told by their lawyers that additional charges would be imposcd if a formal property settlement were drawn up; they dispensed with one. 
the case to be called. As timed by the authors, hearings involving no support orders or property divisions rarely consumed more than three minutes. 202

Where lawyers were called upon to do more, their fees escalated accordingly. Sixty-eight percent ${ }^{203}$ of those plaintiffs whose divorces involved support orders or property awards paid more than $\$ 600$. More than one-quarter ${ }^{20 t}$ of the plaintiffs' fees exceeded $\$ 1000$. The cost of the defendant's attorney, where present, is not included. Such figures are not unique to the two Connecticut counties studied. ${ }^{205}$

Attorney-client friction over fees was common. Sixty percent of the interviewed plaintiffs felt that they had been overcharged for the services rendered. Several reported threats by the lawyer to delay the proceedings unless paid at once in full. ${ }^{206}$ There was repeated confusion over whether retainers tendered initially were or were not intended as payment in full. ${ }^{207}$

These most obvious costs of the monopoly go far to explain the rise of divorce kit entrepreneurialism and patronage. Eighty-seven percent of the pro se plaintiffs interviewed were drawn to the kit primarily because of the financial savings involved. ${ }^{208}$ But there are other costs as well.

202. See p. 129 supra.

203. $34 / 50$ (base less than 65 due to exclusion of 15 interviews in which no response was given).

201. 14/50 (base less than 65 due to exclusion of 15 interviews in which no response was given).

205. In New York City the range of fees for uncontested divorces is $\$ 600-\$ 1000$. Brief of the Legal Aid Society of New York City as Amicus Curiae at 20, In re Smiley, 36 N.Y.2d 433, 330 N.E.2d 53, 369 N.Y.S.2d 87 (1975). The founder of the California Divorce League reports $\$ 500-\$ 750$ as the prevailing range in California. Telephone Interview with Ruth Ordesch, supra note 31. For a discussion of the fee structure in Oregon, see Pagel, supra note 78, at 344-45. See also note 116 supra.

206. One lawyer reportedly enhanced his leverage by noting that "we get paid whether you get divorced or not." Another plaintiff's attorney refused to conduct her court hearing until she paid the last $\$ 200$ of a $\$ 1000$ fee.

Fee disputes may explain some of the delays in the scheduling of hearings which occurred in many lawyer-initiated cases. Normally, the computer-selected hearing date is two to three weeks after the filing of the claim for trial. All 31 pro se divorces were heard on the date initially allotted, within 30 days of the claim for trial. However, the hearing dates of $31.7 \%(99 / 312)$ of the lawyer-initiated cases had to be set back at least once, with $14.7 \%$ (46/312) heard only after two months or more had clapsed following the claim for trial. (Base is less than 331 because data on dates divorces were claimed for a hearing were not collected from first 19 files surveyed).

207. In one instance, a plaintiff told to supplement an initial $\$ 500$ retainer with an unanticipated $\$ 700$ increment was forced to sacrifice savings which had been accumulated toward tuition at a paralegal training center. Five other clients volunteered that initial fec estimates had been unexpectedly increased by $\$ 100-\$ 300$ prior to the hearing.

208. Six of the 47 interviewed pro se plaintiffs were primarily motivated by selfactualizing or feminist considerations in their decision not to hire a lawyer. Such nonpecuniary inducements, while not controlling for the remainder of the group, were mentioncd by $44.7 \%$ of respondents. 
As Table 8 demonstrates, attorneys surveyed for the Project reported substantial amounts of time spent on formalities readily delegable to lay specialists or to pro se plaintiffs themselves.209 Given the rudimentary nature of the activities listed, ${ }^{210}$ the Table 8 data documents a patently inefficient allocation of professional training. Moreover, by restricting such tasks to attorneys, unauthorized practice doctrine contributes to the stereotype of divorce lawyers as overcompensated clerks, a characterization volunteered by many interviewed clients. ${ }^{211}$

\section{TABLE 8}

Lawyer Estimates of Average Amount of Time Spent per Uncontested Divorce Preparing Forms and Waiting in Court for Case to be Heard

\begin{tabular}{lcccc} 
& \multicolumn{5}{c}{ Functions } \\
\cline { 2 - 5 } & $\begin{array}{c}\text { Preparing the } \\
\text { Complaint } \\
(\mathrm{n}=101)^{\mathrm{a}}\end{array}$ & $\begin{array}{c}\text { Procuring } \\
\text { Service by } \\
\text { Registered } \\
\text { Mail }(\mathrm{n}=94)^{\mathrm{a}}\end{array}$ & $\begin{array}{c}\text { Waiting in } \\
\text { Court for Case } \\
\text { To Be Heard } \\
(\mathrm{n}=98)^{2}\end{array}$ & $\begin{array}{c}\text { Preparing } \\
\text { the Decree } \\
(\mathrm{n}=101)^{2}\end{array}$ \\
20 minage Time Expended or less & $49.5 \%$ & $52.1 \%$ & - & $26.7 \%$ \\
$21-30$ min. & $35.6 \%$ & $14.9 \%$ & $1.0 \%$ & $37.6 \%$ \\
$31-60$ min. & $14.9 \%$ & $16.0 \%$ & $29.6 \%$ & $27.7 \%$ \\
More than 60 min. & - & $17.0 \%$ & $69.4 \%$ & $7.9 \%$
\end{tabular}

a Base is less than 106 due to the exclusion of questionnaires in which no response was given.

The heaviest monopoly costs, however, are visited upon the indigent. In New Haven and Bridgeport, legal aid offices can handle only a fraction of the requests for their dissolution services, and are compelled to limit caseloads severely. ${ }^{212}$ That private attorneys have failed

209. To ensure that lawyer estimates would not include time spent by secretaries or paraprofessionals, the questionnaire contained separate requests for average employee time allocated to each function.

210. The mechanics of form preparation in uncontested actions are described at pp. 124-28 supra. The lengthy intervals spent waiting in court represent particularly wasteful expenditures of attorney time, given the perfunctory character of the actual hearings. See p. 129 supra.

211. The low prestige of the matrimonial bar is a recurrent concern in the family law literature. See, e.g., Q. Jolinstone \& D. Hopson, supra note 46, at 564; Foley, The Lawyer's Role in Domestic Relations Cases, 36 OKLA. B.J. 2377, 2377 (1965); Baum, supra note 169 , at 464 .

212. The New Haven practice is to take calls for three to four days, during which time enough divorces are booked to occupy the office for three months. No new divorce clients are accepted until the three month period ends, when the floodgates once again open briefly. Interview with Mary Keller, supra note 96. In Bridgeport a waiting list was initially tried and then discarded in favor of the New Haven approach; at one point the list contained 800 names. Interview with David Snyder, supra note 53.

The problem does not exist only in Connecticut. In New York City, for instance, the 
to meet the excess demand is suggested by the fact that only 21 of the 331 plaintiffs in the lawyer-initiated files $(6.3 \%$ ) were recipients of state welfare assistance. ${ }^{213}$ Absent a constitutionally guaranteed right to counsel in divorce proceedings ${ }^{214}$ or institutional reform, ${ }^{215}$ lowcost lay help in initiating a dissolution is the only practical alternative to consigning the poor of these counties to the extrajudicial remedies endured by their predecessors. ${ }^{216}$

The arguments against lay assistance appear especially suspect when applied to divorces involving indigents. Ancillary issues often invoked

Bronx and Brooklyn legal aid offices can accommodate less than one-half of the applicants for their dissolution services. Brief of the Legal Aid Society of New York City as Amicus Curiac at 17-18, In re Smiley, 36 N.Y.2d 433, 330 N.E.2d 53, 369 N.Y.S.2d 87 (1975). Further, as of 1974, 28 of the 62 counties in New York State had no legal assistance offices. Brief of the Monroc County Legal Assistance Corporation as Amicus Curiae at 9, In re Smiley, 36 N.Y.2d 433, 330 N.E.2d 53, 369 N.Y.S.2d 87 (1975). In 1970, 172,688 persons (11\% of the total population) in these 28 counties were officially classified as indigent. $I d$.

For the nation as a whole, there were only 300 staffed legal assistance programs drawing federal funds in 1972. S. Brakel, Junicare: Public Funds, Private lawyers, and Poor People 6 (1974). Congressional allocations for legal services programs totalled $\$ 100$ million for fiscal year 1976. Legal Services Corporation Act of 1974, 42 U.S.C. $\$ 2996 i$ (a) (Supp. IV 1974). This constitutes less than four dollars for each of the 25.8 million Americans at or below the poverty level. See N.Y. Times, Sept. 26, 1976, at 1, col. 4, and 36, col. 3.

213. Moreover, in only three of these 21 cases was a waiver of court fees applied for. These fees, ustually totaling about $\$ 70$, are described in note 198 supra. The waiver became an entitlement of all indigent divorce plaintiffs after Boddie v. Connecticut, 401 U.S. 371 (1971). Ninety-three percent $(93 / 100)$ of the private attorncys who responded to the Project questionnaire indicated that they had never applied for a Boddie waiver on behalf of an uncontested divorce plaintiff. (Base is less than 106 due to the exclusion of six questionnaires in which no response was given.)

214. For a recent case refusing to recognize such a right despite extensive evidence of the inability of existing sources of free legal services to accommodate more than a fraction of indigents secking divorces, see In re Smiley, 36 N.Y.2d 433, 330 N.E.2d 53, 369 N.Y.S.2d 87 (1975).

215. See pp. 165-66 infra.

216. Fees charged by private attorneys for uncontested dissolutions have long been well beyond the reach of the poor. See ten Broek, California's Dual System of Family Law: Its Origin, Development, and Present Status, Part III, 17 Stan. L. Rev. 614, 617 (1965); Carlin \& Howard, Legal Represenlation and Class Justice, 12 U.C.L.A. L. REv. 381, 397 (1965). And legal assistance programs historically have been neither equipped nor inclined to service the needs of the nation's low income population for divorce adjudications. A 1967 compilation by the National Legal Aid \& Defender Association revealed only 298 civil legal aid offices with paid staff, 90 volunteer offices, and 98 volunteer committees in the entire United States. As of 1972, the total number of paid staff offices was 300 . See note 212 supra. Of the 3100 counties in the United States, 2500 (containing one-third of the national population) had no legal aid facilities whatsoever. Silverstein, Eligibility for Free Legal Services in Civil Cases, 44 J. Unв. L. 549, 555 (1967). Data on 130 offices revealed that in 1966 only 26 had "open" policies concerning divorce: 23 excluded such cases entirely, and 81 had restrictive policies (cases accepted only under circumstances such as physical mistreatment of wife or children, spouse jailed or in mental asylum, or request by a social services agency). Id. at 574-80. For more recent statistics on the continued inability of legal services offices to meet the needs of the poor in dissolution actions, see note 212 supra. 
to justify the lawyer monopoly are of little relevance to the poor. ${ }^{217}$ Predictably, only one of the 46 legal aid divorces sampled for the Project involved a house, and only one produced a formal allocation of property. Less than one-quarter of the defendants in these cases were represented by attorneys; an equal number of defendants not only did not have lawyers but had moved to parts unknown, eliminating any prospect of negotiation. In Table 9, these figures are compared with those obtaining for the lawyer-initiated sample.

To supplement the file data summarized above, the Project's lawyer questionnaire was mailed to five Bridgeport and New Haven legal aid attorneys, four of whom responded. ${ }^{218}$ The two who reported the largest volume of divorces spent an average of only $15-30$ minutes per uncontested case in negotiations with unrepresented defendants, with the figure rising slightly to one hour for actions in which the defendant had secured an attorney.

Although no attempts have been made to quantify the number of low-income individuals who have been deterred from seeking a divorce because of cost, the striking class differential in the incidence of nonlegal separations is suggestive.

TABLE L

Households with Divorced or Separated Head, by Income Category*

A bove Poverty

Line

Head Divorced

Head Separated
$1,134,000(68.0 \%)$

$534,000(32.0 \%)$
Below Poverly

Line

$402,000(41.6 \%)$

$500,000(55.4 \%)$

* Adapted from Bureau of the Census, 1970 Census of Population, Subject Rrjorts PC(2)-9A: Low Income Population 137 (1974) (Table 12).

The extent to which de facto separation functions as a permanent surrogate for legal dissolution is discussed in ten Broek, supra, at $617 \mathrm{n.749}$; and Kay \& Philips, supra note 107, at 727. The possibility that members of lower socioeconomic groups generally prefer informal separation to divorce seems tenuous, in view of the high volume of client demand at legal assistance offices which handle such cases. See N.Y. Times, Sept. 2, 1966, at 16, col. 3 (in first six weeks of Wisconsin Judicare program, $84 \%$ of incoming requests were for divorce); note 212 supra. Cf. Foster, Common Law Divorce, 46 MiNn. L. REv. 43 (1961) (enumerating sociological factors contributing to desertion, yet concluding at 67: "Unless divorce is relatively inexpensive, desertion and self-divorce are bound to occur.")

Those unable to afford a divorce but unwilling to tolerate the uncertainties of de facto separation have resorted to other extralegal remedies, including patently invalid mail order decrees. See Rosenberg, How Void is a Void Decree, or The Estoppel Effect of Invalid Divorce Decrees, 8 FAM. L.Q. 207, 214-15 (1974); Foster, supra at 60-61.

217. See generally Goldberger, Legal Aid Divorces: A Practical Approach, 20 AM. U. L. REv. 30 (1975).

218. These five attorneys handled all 46 legal aid divorces sampled for the Project. The questionnaires which they completed were excluded from the tabulations of private lawyer responses presented elsewhere in the Project. 


\section{TABLE 9}

Percentages of Legal Aid and Lawyer-Initiated Divorces Involving Ancillary Legal Issues

\section{Calegory}

1. Property Award

a. Awards Mentioning Houses

b. Awards Mentioning Automobiles

c. Awards Mentioning Both Houses and Automobiles

2. Alimony Award

a. Lump Sum Alimony

1. $\$ 1-5000$

2. $\$ 5000+$

b. Periodic Alimony

1. $\$ 1 / \mathrm{yr}$

2. $\$ 5-50 / \mathrm{wk}$

3. $\$ 51+/ w k$

3. Separation Agreement Filed

4. Home Ownership Listed in File

5. Defendants Represented by an Attorney

6. Defendant's Whereabouts Unknown

Child Support Award in Cases Involving Minor Children

a. $\$ 25 /$ wk or less

b. $\$ 26-50 / w k$

c. $\$ 51+/ w k$
Relative reqquency

\begin{tabular}{cc}
\hline $\begin{array}{c}\text { Lawyer-Initiated } \\
\text { Cases }(\mathrm{n}=331)\end{array}$ & $\begin{array}{c}\text { Legal Aid Cases } \\
(\mathrm{n}=46)\end{array}$ \\
$23.9 \%$ & $2.2 \%$ \\
$18.0 \%$ & 0 \\
$(\mathrm{n}=328)^{\mathrm{a}}$ & \\
$7.3 \%$ & \\
$(\mathrm{n}=328)^{\mathrm{a}}$ & 0 \\
$4.6 \%$ & \\
$(\mathrm{n}=328)^{\mathrm{a}}$ & 0 \\
$42.3 \%$ & \\
$9.1 \%$ & $47.8 \%$ \\
$6.9 \%$ & 0 \\
$2.1 \%$ & 0 \\
$34.1 \%$ & 0 \\
$13.4 \%$ & $47.8 \%$ \\
$(\mathrm{n}=329)^{\mathrm{a}}$ & $22.2 \%$ \\
$15.8 \%$ & $(\mathrm{n}=45)^{\mathrm{b}}$ \\
$(\mathrm{n}=329)^{\mathrm{a}}$ & $24.4 \%$ \\
$4.6 \%$ & $(\mathrm{n}=45)^{\mathrm{b}}$ \\
$(\mathrm{n}=329)^{\mathrm{a}}$ & 0 \\
& $(\mathrm{n}=45)^{\mathrm{b}}$
\end{tabular}

$\begin{array}{cr}26.9 \% & 8.7 \% \\ 35.3 \% & 2.2 \% \\ 43.9 \% & 23.9 \% \\ (\mathrm{n}=330)^{\mathrm{a}} & \\ 4.8 \% & 26.1 \% \\ & \\ 88.2 \% & 75.0 \% \\ (\mathrm{n}=161)^{\mathrm{c}} & \\ 24.4 \% & 33.3 \% \\ (\mathrm{n}=156)^{\mathrm{c}} & \\ 34.0 \% & 30.6 \% \\ (\mathrm{n}=156)^{\mathrm{c}} & \\ 29.5 \% & 11.1 \% \\ (\mathrm{n}=156)^{\mathrm{c}} & \end{array}$

a Base is less than 331 due to the exclusion of files for which data were inadvertently omitted.

base is less than 46 due to the exclusion of files for which data were inadvertently omitted.

c Base is less than 162 due to the exclusion of files for which data were inadvertently omitted.

'Thirty-six" of the legal aid cases involved minor children. 
With regard to spousal and child support in cases involving indigents, it should be noted that a lawyer from the state attorney general's office participates in the determination of awards for Connecticut plaintiffs on welfare. ${ }^{219}$ With the state thus intervening to assert the plaintiff's support interests, his attorney's contribution here is largely redundant.

\section{Directions for Reform: The Limited Utility of Published Kits}

From December 1974 through May 1976, a total of 63 pro se dissolutions were concluded in New Haven Superior Court. ${ }^{220}$ During that same interval, the court processed a total of approximately 2,500 uncontested divorces.221 The lawyer monopoly has scarcely been challenged.

The low level of kit utilization is to some extent attributable to local bar association warnings not to advertise. ${ }^{222}$ Also significant is a caveat in the Pro Se Dissolution Kit defining the "ideal" pro se couple as one without children, financial interdependence, or unresolved questions concerning property. ${ }^{223}$ Yet even if this warning were universally heeded, it appears that there would still be a substantial number of potential pro se plaintiffs. Of the Project's 331 lawyerinitiated actions, $112(33.8 \%)$ involved neither children nor any award of property or alimony. Thus, perhaps the most important limiting factor is the threshold level of education, self-confidence, and clerical

219. CoNN. GEN. STAT. \$ 46-63(a) (1975). Fifty-nine percent (27/46) of the plaintiffs in the sampled legal aid cases were recipients of state welfare assistance.

220. Thirty-one pro se divorces were heard in New Haren during the period under study for the Project (December 1974 through October 1975), with 32 following in the seven subsequent months. No pro se dirorces were filed in Bridgeport during this 18 . month interval.

221. This total was obtained by extrapolating from the 1,943 uncontested actions heard between April 1, 1975 and May 31, 1976.

222. Telephone Interview with Karen Wynn, Pro Se Dissolution Group member (Dec. 4, 1975). These threats appear to have tenuous legal grounding at best. It seems clear from the Connecticut Supreme Court decision in Grievance Comm. v. Dacey, 154 Conn. 129, 222 A.2d 339 (1966), appeal dismissed, 386 U.S. 683 (1967) (lay estate-planning advice) that Connecticut unauthorized practice doctrine would permit the publication of a divorce kit. The Dacey rationale, emphasizing "personalized" information directed to the particular needs of an individual as the crux of unauthorized practice, has been adopted in New York and Oregon decisions refusing to bar publication. See pp. 112-13 supra. It follows that, as the Oregon Court of Appeals declared: "[I]f the defendants may sell the divorce kits, we think they can advertise the purpose for which they have been prepared and offered for sale." Oregon State Bar v. Gilchrist, 538 P.2d 913, 917 (Or. App. 1975).

223. Pro Se Dissolution Group, supra note 68, at 2. 
competence presumed by this or any other carefully prepared do-ityourself publication..$^{24}$

As might be anticipated in view of the foregoing discussion, the demographic profiles of Connecticut pro se plaintiffs contrast sharply with those of clients in the Project's lawyer-initiated pool. Seventy-six percent of the interviewed pro se plaintiffs had at least some college background; $91.5 \%$ were under $35 ; 64.9 \%$ had been separated from their spouses for over six months when they filed complaints. ${ }^{25}$ The atypicality of these kit users is further highlighted by the fact that

224. Initially, the prospective Connecticut kit user must assimilate 15 terse singlespaced pages which detail every aspect of form preparation. Id. at 1-15. There follows a three-page glossary of technical terms. Users are cautioned to "follow the given legal format" and to make no typographical errors. Id. at 11. Finally, there is a checklist of 68 items detailing literally every move required in the progression from complaint to hearing. $I d$. at $18-20 \mathrm{a}$.

225.

TABLE M

Comparison of Pro Se Plaintiffs and Interviewed Clients: Education, Age, and Length of Separation*

$\begin{array}{cc}\text { Interviewed Pro } & \text { Interviewed } \\ \text { Se Plaintiffs }(\mathrm{n}=47) & \text { Clients }(\mathrm{n}=99)\end{array}$

\section{A. EDUCATION}

Less than Four Years of High School High School Graduate Some College

$$
\begin{array}{r}
2.2 \% \mathrm{a} \\
21.7 \%^{\mathrm{a}} \\
76.1 \%^{\mathrm{a}}
\end{array}
$$

$$
\begin{array}{r}
5.1 \% \%^{b} \\
43.9 \%^{b} \\
51.0 \% \%^{b}
\end{array}
$$

B. AGE

Under 25

25-34

$21.3 \%$

$70.2 \%$
$8.5 \%$

$$
\begin{aligned}
& 11.2 \% \%^{b} \\
& 37.8 \%^{b} \\
& 51.0 \%^{b}
\end{aligned}
$$

\section{LENGTH OF SEPARATION BEFORE COMPLAINT FILED}

\section{None}

I.6 Months

6-24 Months

More than 24 Months

$-35.1 \%$
$48.6 \%$
$16.2 \%$

$$
\begin{array}{r}
39.4 \% \\
24.2 \% \\
27.3 \% \\
9.1 \%
\end{array}
$$

* The education, age, and separation contrasts between interviewed pro se plaintiffs and interviewed clients are statistically significant at the $.02, .001$, and .001 levels respectively. These categories of data were not available for plaintiffs in the lawyerinitiated sample who were not interviewed.

* Only one of the interviewed pro se plaintiffs was over 45, compared with 22 $(22.4 \%)$ of the interviewed clients.

a Base is 46 due to the exclusion of one interview in which no response was given. was given.

${ }^{b}$ Base is 98 due to the exclusion of one interview in which no response was given. was given.

c Base is 37 because the first 10 pro se plaintiffs interviewed were not questioned about their separations. 
their marriages were without exception childless and, in all but four cases, of less than 10 -years duration. ${ }^{226}$

Forty-nine of the 96 kit purchasers interviewed had decided not to attempt kit use, at least for the present. ${ }^{227}$ Usually the delay was a product of factors unrelated to the kit (e.g., ambivalence concerning the divorce itself, ${ }^{29 s}$ need to comply with residence requirements), but in 15 cases $(30.6 \%)$ the primary impediment was a lack of confidence in capacity to negotiate the process unaided. ${ }^{229} \mathrm{~A}$ number of purchasers were intimidated by the kit's exhaustive step-by-step explanations and warnings about possible hostility toward pro se plaintiffs on the part of clerks and judges. Others cited a lack of time, ${ }^{230}$ typing skills, or a typewriter as factors militating against use. Several respondents chafed

226.

TABLE N

Comparison of Pro Se and Lawyer-Initiated Actions: Presence of Minor Children and Duration of Marriage*

\section{A. MINOR CHILDREN}

No Minor Children

Minor Children Involved

\section{B. DURATION OF MARRIAGE}

Under 3 Years

3-9.9 Years

10-19.9 Years

20 or More Years
Interviewed Pro Se

Plaintiffs $(\mathrm{n}=47)$
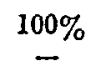

$34.0 \%$
$57.4 \%$
$8.5 \%$
Lawyer-Initiated

Actions $(\mathrm{n}=331$ )

$51.3 \% \%^{\mathrm{a}}$ $48.7 \% \%^{a}$

$22.8 \%^{\mathrm{b}}$
$42.3 \%^{\mathrm{b}}$
$19.1 \%^{\mathrm{b}}$
$15.7 \%^{\mathrm{b}}$

* The contrasts revealed in Table $N$ are statistically significant at the .001 and .01 levels respectively.

a Base is $\mathbf{3 3 0}$ due to the exclusion of one file for which data were inadvertently omitted.

b Base is 324 due to the exclusion of seven files for which data were inadvertently omitted.

227.

TABLE O

Reasons Given by Kit Purchasers For Not Kaving Proceeded with a Pro Se Divorce Action $(n=49)$

Plan To Use Kit at Some Future Date

Unsure about Divorce

Lack Confidence in Capacity To Proceed without Assistance

Uncooperative Spouse/Unresolved Issues

Other

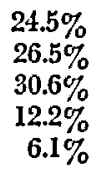

228. This was the case for 13 respondents. One such woman was relieved at the flexibility the kit gave her in arriving at a decision. She had been coacerned that payment of a retainer to a lawyer would have had the effect of locking her into the dissolution process.

229. In two especially poignant instances, deterred purchasers with neither a high school education nor funds to hire a lawyer were seeking divorces after 31 and 24 year separations from their respective spouses.

230. The possibility of repeated trips to the courthouse as a result of errors and/or harassment by clerks discouraged kit purchasers with inflexible work schedules. 
at the kit's failure to provide information for couples with offspring. ${ }^{231}$

The Project's data do not permit firm conclusions about the potential universe of unassisted kit users, ${ }^{232}$ but reports from West Coast distributors tend to corroborate the limitations suggested by the New Haven experience. A moderate-volume Oregon center fo: kit sales and form processing advice found that only half of its customers were able to conduct their actions without aid from staff members. ${ }^{233}$ Similarly, the founder of California's consortium of pro se divorce enterprises stated in an interview with the authors that form preparation assistance was essential for "most" clients, especially those of limited education. . $^{34}$

It is clear that the emergence of a divorce kit in Connecticut has brought no measurable relief to the area's indigent population. Only $20.5 \%{ }^{235}$ of interviewed users reported joint incomes below $\$ 5,000$ per year, and several of these were students on the verge of substantially increased earnings. Moreover, none of the plaintiffs who engineered New Haven's 31 completed pro se divorces were recorded in the court files as being recipients of state welfare assistance. Financial savings made possible by the kit have accrued only to a small minority of relatively young and well-educated couples.

Given the difficulties inherent in unassisted kit use, those jurisdictions that permit kit publication but not personalized lay assistance to users are, in effect, precluding pro se representation by a substantial number of divorce plaintiffs. Where only a kit is available, individuals who lack the requisite assimilative capacities, typing skills, or selfconfidence will be deterred from proceeding pro se. Such capabilities are uncharacteristic of the low-income population. Yet, as was previously suggested, indigents are also the group least able to employ a

231. One woman submitted that her offspring would be the "real losers" if she had to pay the $\$ 800$ quoted to her by an attorney. All necessary financial arrangements had been settled.

232. The pro se divorces studied were limited not only in number, see p. 122 supra, but in complexity as well, perhaps in part because the Connecticut kit expressly declines to give instructions tailored to parties with children. Files for the 31 New Haven pro se divorces indicate that only one involved children or financial awards. The plaintiff in the aberrant case was a man with four children; the divorce decree incorporated a support agreement signed by the husband and wife. Unfortunately no telephone listing was available for either spouse, and hence no interview was possible. None of the pro se divorce actions surveyed produced a formal award of real or personal property.

233. See Orcgon State Bar v. Gilchrist, 538 P.2d 913, 917 (Or. App. 1975). The center handled roughly 600 clients a year. $I d$.

234. Telephone Interview with Ruth Ordesch, supra note 31.

235. $9 / 44$ (base less than 46 due to exclusion of two interviews in which no response was given). 
lawyer and least likely to have divorces involving the ancillary financial issues that cause concern to critics of pro se divorce. ${ }^{236}$

\section{Conclusion}

With his customary prescience, Karl Llewellyn concluded in 1933 that financial impediments to uncontested divorce were unsupportable:

[F]rom the standpoint of the litigants and of society, in all cases of actual mutual acquiescence the costs are unnecessary. As a device to make divorce difficult they are not only unnecessary (because time-periods can do the work more effectually than the present money-costs do), but they are undesirable (because distribution of divorce-facilities by income is a social outrage). Socially, the costs are . . pure wastes. ${ }^{237}$

The demise of the fault system has deflated but by no means removed the costs of divorce in cases of mutual acquiescence. The procedural vestiges of an adversary system which remain, coupled with an expansive doctrine of unauthorized practice of law, have forced most divorce plaintiffs to assume the considerable expense of employing a lawyer. Yet the procedural prerequisites of a dissolution action are, in large part, anomalous and dysfunctional.

Insofar as procedural complexity performs a salutary function by deterring hasty, ill-conceived divorces, that purpose could better ie served by temporal rather than fiscal impediments. The present structure checks only those individuals who cannot afford a lawyer and who lack the competence and confidence to navigate the system without assistance. ${ }^{238}$

If, however, procedural complexity is defended as a means of requiring parties to employ legal intermediaries, then convincing reasons for preserving that requirement must be demonstrated. The empirical data assembled for this Project suggest the difficulty of making such a showing. Neither the arguments traditionally used to buttress unauthorized practice prohibitions nor the frequent references by surveyed practitioners to negotiation and counseling contributions

236. See pp. 158-59 supra.

237. Llewellyn, Behind the Law of Divorce: II, 33 Colum. L. Rev. 249, 286 (1933).

238. To the extent that these personal attributes are inversely correlated with income, the system operates in a particularly objectionable fashion. At present, many of those least likely to be able to proceed pro se without individualized assistance are those least able to afford a private attorney. See In re Smiley, 36 N.Y.2d 433, 448 n.2, 330 N.E.2d 53, 62 n.2, 396 N.Y.S.2d 87, 100 n.2 (1975) (Fuchsberg, J., dissenting); p. 163 supra. 
provide an adequate rationale. When the costs of excluding lay competition are added to the calculus, the case for reform becomes compelling.

The conclusion is inescapable that the formalities requisite to divorce need not be the exclusive domain of lawyers. From this flow two corollaries. The first is that the public should not be denied access to lay divorce assistance. ${ }^{239}$ Laymen can safely be permitted to offer personalized form preparation aid and to publish kits. If abuses develop, the states retain the option to impose civil liability or institute licensing requirements. ${ }^{240}$

A second, more elemental proposition is that there are major social costs involved in imposing the Procrustean frame of an adversarial system upon nondisputants. It generates needless expense for the parties $^{241}$ and a less than optimal allocation of the expertise of lawyers and judges. ${ }^{242}$ For divorces that involve no substantive contest, an administrative rather than an adversarial model is apposite.

239. It should be noted that statutes which permit dissemination of lay assistance will be vulnerable to judicial nullification in states where the judiciary has asserted an inherent power to regulate the practice of law. This frequently claimed prerogative is discussed in HANDBook, supra note 30, at 3-5, and Comment, Control of the Unauthorized Practice of Law: Scope of Inherent Judicial Power, 28 U. CHI. L. REv. 162, 163 (1960). Its exercise has led in the past to summary invalidations of various legislative efforts to enlarge the class of activities permitted to nonlawyers. See, e.g., Clark v. Austin, 340 Mo. 467, 475, 101 S.W.2d 977, 981 (1937); Washington State Bar Ass'n v. Washington Ass'n of Realtors, 41 Wash. 2d 697, 699-700, 251 P.2d 619, 621 (1952); West Virginia State Bar Ass'n v. Early, 144 W. Va. 504, 533, 109 S.E.2d 420, 438 (1959). The only jurisdiction that makes explicit provision for legislative regulation of the practice of law is New York. HandBook, supra note 30 , at 5 .

240. To date there has been no showing of injury to the public deriving from lay personalized or published divorce assistance. See pp. 113-14 supra. Negligence by lay practitioners in other legal contexts has been held to afford a cause of action for damages to injured clients or adversely affected third parties. E.g., Biakanja v. Irving, 49 Cal. 2d 647, 320 P.2d 16 (1958) (invalid will); Latson v. Eaton, 34I P.2d 247 (Okla. 1959) (negligent preparation of legal documents); Hecomovich v. Nielson, 10 Wash. App. 563, 518 P.2d 1081 (1974) (real estate transaction). See Mattieligh v. Poe, 57 Wash. 2d 203, 204, 356 P.2d 328, 329 (1960) (adverting to legitimacy of such remedy).

States might also institute licensing programs which set ethical standards and define permissible activities by lay divorce firms. Such a proposal has the support of the California Divorce League, a consortium of lay advisors. Telephone Interview with Ruth Ordesch, supra note 31. A detailed plan for oversight of lay divorce businesses is presented in Note, supra note 32 , at $443-46$.

241. Even assuming that low-cost lay assistance with form preparation is allowed to proliferate, the question rhetorically posed by Llewellyn persists: "[W] $[$ hy continue paying specialists for useless work"? Llewellyn, supra note 237, at 286. Or, as Marshall and May phrased it:

The question still remains whether the character of the work actually required is such as to justify the utilization of such a cumbersome machine with its concomitant costs and fees: whether "judicial controversy" is a basis of divorce which is today reasonably economical of time, effort, and money.

1 L. Marshall \& G. May, The Divorge Court 283 (1932).

242. See p. 156 supra (lawyer estimates of clerical and waiting time expended on average uncontested dissolution). The largely perfunctory character of the judicial 
A bifurcated system which employs hearings for contested divorces and registration coupled with a waiting period for uncontested dissolutions has been implemented in Japan, Denmark, Norway, Iceland, and Sweden, ${ }^{243}$ and has been advocated intermittently in the United States. ${ }^{244}$ Its principal advantage is self-evident. Removing the intimidating procedures that attend dissolution would enable many persons to do without any formal assistance-lay or legal-when terminating a marriage, thereby decreasing costs and pricing divorce within the means of all couples who desire it.

The empirical findings of this Project cannot purport to supply a blueprint for the overhaul of the nation's divorce system. They do, however, suggest directions in which future study and reform might profitably proceed. Until institutional modifications occur, a demand for kit and lay services for pro se plaintiffs will persist. The data here compiled demonstrate no persuasive justification for enjoining such assistance.

role is suggested by the extreme brevity of individual hearings, discussed at p. 129 supra. New Haven and Bridgeport judges seem to be typical in this regard. The vast majority of domestic relations judges who responded to a poll by Quenstedt and Winkler estimated that they rejected the proposed property dispositions, child support awards, and custody allocations in less than $10 \%$ of their cases. J. QUENSTEDT \& C. WINkLER, supra note 168 , at unnumbered p.2.

243. In every year between 1948 and 1959 , over $90 \%$ of Japanese divorces were accomplished by simple communication of the parties' agreement to a state registrar. Custody arrangements are submitted to a family court for approval. Parties who fail to reach a consensus on either divorce or its terms are heard first before a conciliation committee of the family court and then, if disputes persist, before a district court. M. Rheinstein, supra note $\breve{5}$, at 109-11.

In Denmark, Norway, and Iceland, all but a small minority of divorces are granted by administrative agencies in "a well-established, inexpensive procedure." Id. at 131. The Swedish practice is to grant dissolutions automatically upon the joint request of a couple without children under 16. Where minor children are involved or a unilateral application has been made, a divorce issues after a six-month waiting period. Sage, Dissolution of the Family Under Swedish Law, 8 FAm. L.Q. 375 (1975).

244. See generally Goldberger, supra note 217; Goldstein \& Gitter, supra note 8; Llewellyn, supra note 237; Note, supra note 8. 


\section{APPENDIX 1}

\section{A. Suits Against Lay Divorce Enterprises}

\begin{tabular}{|c|c|c|c|c|c|}
\hline State & $\begin{array}{l}\text { Form } \\
\text { Preparation } \\
\text { Services } \\
\text { Offered? }\end{array}$ & $\begin{array}{c}\text { Price } \\
\text { Charged } \\
\text { for Kits } \\
\text { (and Ser- } \\
\text { vices if } \\
\text { Available) }\end{array}$ & $\begin{array}{c}\text { Plaintiff } \\
\text { in Suit }\end{array}$ & $\begin{array}{c}\text { Kit Sale } \\
\text { Enjoined? }\end{array}$ & $\begin{array}{c}\text { Form } \\
\text { Preparation } \\
\text { Services } \\
\text { Enjoined? }\end{array}$ \\
\hline Alaska ${ }^{1}$ & No & $\$ 50$ & $\begin{array}{l}\text { Alaska } \\
\text { Bar Ass'n }\end{array}$ & Yes & Not offered \\
\hline Florida ${ }^{2}$ & No & $\$ 20.80$ & $\begin{array}{l}\text { Florida } \\
\text { Bar Ass'n }\end{array}$ & Yes & Not offered \\
\hline California $^{3}$ & Yes' & $\$ 75$ & $\begin{array}{l}\text { State Bar of } \\
\text { California }\end{array}$ & No & Yes \\
\hline Colorado & Yes & $\$ 80-160$ & $\begin{array}{l}\text { Colorado } \\
\text { Bar Ass'n }\end{array}$ & No & Yes \\
\hline Florida $^{5}$ & Yes & $\$ 187$ & $\begin{array}{l}\text { Florida } \\
\text { Bar Ass'n }\end{array}$ & Yes & Yes \\
\hline Michigan $^{0}$ & Yes & $\$ 800-100$ & $\begin{array}{l}\text { State Bar } \\
\text { of Michigan }\end{array}$ & Unclear & Yes \\
\hline Minnesota ${ }^{8}$ & Yes & N.A. & $\begin{array}{l}\text { Minnesota State } \\
\text { Bar Ass'n }\end{array}$ & Yes & Yes \\
\hline New York ${ }^{\circ}$ & Yes & $\$ 100-125$ & $\begin{array}{l}\text { New York } \\
\text { Attorney } \\
\text { General's Office }\end{array}$ & No & Yes \\
\hline Nevada ${ }^{10}$ & Yes & $\$ 75$ & $\begin{array}{l}\text { State Bar } \\
\text { of Nevada }\end{array}$ & Yes & Yes \\
\hline Oregon $^{12}$ & Yes & $\$ 40-55$ & $\begin{array}{l}\text { Oregon State } \\
\text { Bar Ass'n }\end{array}$ & No & Yes \\
\hline
\end{tabular}

1. Alaska Bar Ass'n v. Foster, C.A.' No. 73-161 (Super. Ct. Alas., Oct. 29, 1973), reported in Alaska Bar Ass'n v. Foster, et al., 38 UNAUTH. PRAc. News 75, 75-80 (1974); telephone interview with Randall J. Weddle, Esq., attorney for plaintiffs (Aug. 4, 1976) (notes on file with Yale Law Journal).

2. Florida Bar v. Stupica, 300 So. 2d 683 (1974); letter to authors from William B. Wiley, Esq., Assistant Staff Counsel for the Florida Bar (July 26, 1976) (on file with Yale Law Journal).

3. State Bar v. Corey, No. 157163 (Cal. Super. Ct. San Bernadino County, Oct. 11, 1973), reported in California Restrains "No-Fault Divorce Consultation Service," 38 UNAUTH. PrAC. NEWS 44, 44-52 (1974).

4. Colorado Bar Ass'n v. Bratt, No. C50833 (Colo. Dist. Ct. Denver, Feb. 1975), reported in Colorado Bar Association Starts Suit Against Lay Divorce Specialists, 39 UNAuth. Prac. News 87-91 (1975); telephone interview with Alex Keller, Esq., attorney for plaintiffs (July 19, 1976) (notes on file with Yale Law Journal).

5. Florida Bar Ass'n v. American Legal \& Business Forms, 274 So. 2d 225 (Fla. 1973).

6. State Bar v. Graham, No. 72-218-571-CZ (Mich. Cir. Ct., Dec. 18, 1972), cited in More on Do-It-Yourself Divorce Kits and Services, 37 Unauth. Prac. News 59, 66-67 (1973); telephone interview with John B. Lisa, Esq., Past Chairman, Michigan State Bar Comm. on the Unauthorized Practice of Law (June 17, 1976) (notes on file with Yale Law Journal).

7. In pertinent part, the Michigan injunction forbids defendants to "furnis[h] or offe[r] to furnish kits, forms or documents, with assistance in their completion or execution, to persons secking to dissolve a marital relationship." State Bar v. Graham, No. 
72-218-571-CZ (Cir. Ct. Mich., Dec. 18, 1972), reported in More on Do-It-Yourself Divorce Kits and Services, 37 Unauth. Prac. News 59, 66 (1973).

8. Minnesota State Bar Ass'n v. Divorce Reform, Inc., No. 396447 (Dist. Ct. Minn., April 18, 1975), reported in Minnesota Bar Wins Sweeping Victory Against a Lay Practitioner of Divorce Law, 39 Unauth. PrAc. News 187, 188-93 (1975).

9. State v. Winder, 42 App. Div. 2d 1039, 348 N.Y.S.2d 270 (1973).

10. State Bar v. Brandon (Nev. Dist. Ct. Clark County, Aug. 23, 1972), reported in Nevada Divorce, 37 Unauth. Prac. News 32, 37-42 (1973).

11. Oregon State Bar v. Gilchrist, 538 P.2d 913 (Or. App. 1975).

B. The following is a list of all other kits and services known to the Project authors.

Kits

Price

C. Allen, How to Ger a New York Divorce for UNDER \$100 (1975) (authored by layman).

Divorce Reform Inc., Do Your OWn Divorce In Maine (undated) (authored by panel of laymen and attorneys).

Pro Se Dissolution Group, Pro Se Dissolution Kit (1975) (Connecticut) (authored by laymen).

\section{NA}

$\$ 2.95$

C. Sherman, How to Do Your Own Divorce In Calfornia (1975) (authored by attorney).

D. Williams \& P. Black, The \$27 Divorce (1972) (Colorado) (coauthored by attorney).

Wisconsin kit, title unknown, described in More On Do-It-Yourself Divorce Kits and Services, 37 Unauth. Prac. News 59, 71-72 (1973).

50.00

Services

California Divorce League, consortium of 21 walk-in offices, described in Wall St. J., Sept. 3, 1976, at 1, col. 1, and note 25 supra.

60.00

75.00

Minnesota agency, name unknown, described in More On Do-It-Yourself Divorce Kits and Services, 37 UnAuth. Prac. News 59, 67 (1973).

115.00

Seattle Women's Divorce Cooperative, described in Women's LEgal Center of San Francisco, Getting Out: A Collective Experience in Self-Help Divorce (1974).

Wisconsin women's group, name unknown, described in More On Do-It-Yourself Divorce Kits and Services, 37 Unauth. Prac. News 70-72.

Women's Legal Center of San Francisco, described in WoMen's Legal CENTER of San Francisco, Getting Out: A Collective Experience in Self-Help Divorce (1974). 


\section{APPENDIX 2}

\section{Data Recorded From Divorce Files}

1. Interval between filing of complaint and claim for hearing.

2. Date of dissolution decree.

3. Grounds for dissolution.

4. Duration of marriage.

5. Number of minor children.

6. Plaintiff's claims for relief.

7. Awards made to plaintiff (type and composition).

8. Name and address of plaintiff's attorney.

9. Whether defendant was represented by an attorney.

10. Plaintiff's income and assets, if listed.

11. Defendant's income and assets, if listed.

12. Whether plaintiff was a recipient of state welfare assistance.

13. Whether the following were included in file:

a. Affidavit regarding custody of minor children.

b. Stipulation of irretrievable breakdown.

c. List of witnesses.

d. Service by publication or registered mail.

e. Military affidavit.

f. Motion to waive fees and costs for indigent plaintiff.

g. Other motions.

14. Detailed summary of contents of separation agreement.

\section{APPENDIX 3}

\section{Telephone Interview Form For Clients}

1. How long was the first interview that you had with your lawyer after you decided to get a divorce?

2. Between that first interview and your court hearing at the end, roughly how many times did you talk with your lawyer?

Personal interviews ......... Phone conversations

3. Had you and your spouse worked out an agreement on how to divide your property before you first went to see your lawyer? $\square$ Yes $\square$ No

A. (If Yes) Did your lawyer suggest changes, or did your agreement remain the same? 
B. (If No) Did your lawyer help you to negotiate an agreement, or did you later work things out between yourselves?

4. Before you first went to see your lawyer, did you and your spouse reach agreement on alimony (and child support)? $\square$ Yes $\square$ No

A. (If Yes) Did your lawyer suggest changes, or did your agreement remain the same?

B. (If No) Did your lawyer help you to negotiate an agreement, or did you later work things out between yourselves?

5. Were custody and visitation settled between you and your spouse before you first went to see your lawyer?

$\square$ Yes $\square$ No

A. (If Yes) Did your lawyer suggest changes, or did your agreement remain the same?

B. (If No) Did your lawyer help you to negotiate an agreement, or did you later work things out between yourselves?

6. Did your lawyer prepare a written separation agreement which was signed by you and your spouse?

$\square$ Yes

$\square$ No

7. As part of his work in getting your divorce, did your lawyer give you any advice on tax matters involved in the settlement? $\square$ Yes $\square$ No

8. Was there a house involved? $\square$ Yes $\square$ No

9. Did the lawyer help you in any other ways?

10. Did your lawyer at any time suggest or advise reconciliation between you and your spouse? $\square$ Yes $\square$ No

11. Did you receive personal counseling about the divorce from any source? $\square$ Yes $\square$ No Source (s):

12. How much did the lawyer charge you for handling your divorce?

13. Do you feel it was a fair price for the services performed?

14. Was your spouse represented by an attorney?

15. Duration of marriage ........ Length of separation ......... Age ........ Education: Own ........ Spouse ........ Income (joint) $\ldots \ldots \ldots$. Occupation at time of divorce: $\ldots \ldots \ldots$ Own ................ Spouse

16. Do you have any additional comments? 


\section{APPENDIX 4}

\section{Lawyer Questionnaire}

1. Circle the category which best describes your law practice:
A. Legal Aid
B. Single Practitioner
C. 1-3 Partners
D. $4+$ Partners

2. For how many years have you been handling divorce (marital dissolution) cases?

3. Roughly how many divorces did you personally handle for plaintiffs in the last year? . . . . . . For defendants? .........

4. Of the uncontested* divorces which you have handled for plaintiffs since the enactment of the 1973 Connecticut Dissolution of Marriage Act:

What percentage involve minor children?
A. $0.20 \%$
B. $20-40 \%$
C. $40-60 \%$
D. $60-80 \%$
E. $80-100 \%$

What percentage (of those involving minor children) involve substantive disputes over child support which require you to negotiate an agreement?
A. $0.20 \%$
B. $20-40 \%$
C. $40-60 \%$
D. $60-80 \%$
E. $80-100 \%$

What percentage (of those involving minor children) involve substantive disputes over custody and/or visitation which require you to negotiate an agreement?
A. $0.20 \%$
B. $20-40 \%$
C. $40-60 \%$
D. $60-80 \%$
E. $80-100 \%$

What percentage (of all the uncontested divorces) involve substantive disputes over alimony which require you to negotiate an agreement?
A. $0.20 \%$
B. $20-40 \%$
C. $40-60 \%$
D. $60-80 \%$
E. $80-100 \%$

What percentage (of all the uncontested divorces) involve substantive disputes over division of property which require you to negotiate an agreement?
A. $0.20 \%$
B. $20-40 \%$
C. $40-60 \%$
D. $60-80 \%$
E. $80-100 \%$

What percentage (of all the uncontested divorces) involve a written separation agreement?
A. $0.20 \%$
B. $20-40 \%$
C. $40-60 \%$
D. $60-80 \%$
E. $80-100 \%$

5. Please estimate the average amount of time spent completing the following, where necessary, when representing the plaintiff in an uncontested divorce action. In some categories, estimates are requested both for your time and for that spent by supervised secretaries and paraprofessionals (e.g. typing, filing, research). Please record your time in hours or fractions of hours, and keep in mind that each category refers to 
uncontested actions handled since the enactment of the 1973 Connecticut Dissolution of Marriage Act.

Initial client interview

Preparing complaint: Your time

Supervised employee time

Securing waiver of court fees for indigent plaintiffs:

Your time

Supervised employee time

$\square$ Never been necessary

Procuring service by registered mail upon absent defendant:

Your time ...........

Supervised employee time

Never been necessary

Procuring service by publication upon absent defendant:

Your time, preparation

Your time, court: arguing motion ; waiting

Supervised employee time, preparation

$\square$ Never been necessary

Motion for alimony/child support/counsel fees pendente lite:

Your time, preparation

Your time, court: arguing motion ; waiting

Supervised employee time, preparation

Drawing up financial affidavit for plaintiff:

Your time, preparation ...........

Supervised employee time, preparation

Negotiations with defendant (if defendant has no lawyer)..$\ldots \ldots$.

Negotiations with defendant's lawyer

Preparing military affidavit: Your time

Supervised employee time

Preparing client for trial

Court time, dissolution hearing: Presenting case

Waiting

Preparing judgment for certification:

Your time

Supervised employee time

Other (please specify): 
6. On the average, when representing plaintiffs in uncontested actions, how often do you talk to your client between the time of the initial interview and the final dissolution hearing?

No. of personal interviews .... ; No. of phone conversations .....

7. What percentage of the dissolutions which you have initiated were dismissed for failure to prosecute, or withdrawn for any reason?
A. $0-20 \%$
B. $20-40 \%$
C. $40-60 \%$
D. $60-80 \%$
E. $80-100 \%$

8. In what percentage of your uncontested actions is it necessary to threaten post-decree legal action on behalf of your client?
A. $0-20 \%$
B. $20-40 \%$
C. $40-60 \%$
D. $60-80 \%$
E. $80-100 \%$

9. In what percentage of your uncontested actions do you actually file post-decree motions on behalf of your client?
A. $0-20 \%$
B. $20-40 \%$
C. $40-60 \%$
D. $60-80 \%$
E. $80-100 \%$

10. What do you see as the lawyer's most important functions in an uncontested divorce action?

"By "uncontested" are meant those cases which culminate in an uncontested hearing.

\section{APPENDIX 5}

\section{A. Telephone Interview Form for Pro Se Plaintiffs}

1. At what stage are you in your divorce proceeding?

2. Why did you decide to represent yourself?
Money:
$\square$ Primary
Secondary

3. Did you talk to a lawyer before deciding to represent yourself?

$\square$ Yes $\square$ No

4. How did you hear about the divorce kit?

5. Did you have any major difficulties using the kit? $\square$ Yes $\square$ No

6. Apart from the kit, did you have any difficulty representing yourself? $\square$ Yes $\square$ No

7. What would you have done if no kit had existed?

8. Would you have delayed your divorce? $\square$ Yes $\square$ No

9. In handling the legal action, did you get any assistance from anyone? $\square$ Yes $\square$ No If so, from whom was it obtained, and could you have proceeded without it?

10. Would legal counseling from an attorney have been helpful?

$\square$ Yes $\square$ No

11. Would a lawyer's assistance in working out a property settlement have been useful?

$\square$ Yes $\square$ No 
12. Would any personal counseling have been helpful? $\square$ Yes $\square$ No If so, about what and from whom?

13. Did you have any problems in getting the cooperation of clerks?

$\square$ Yes $\square$ No If so, of what sort?

14. Did you have any problems in getting the cooperation of judges?
$\square$ Yes
$\square$ No If so, of what sort?

15. Were you or your spouse influenced by the existence of the kit in your decision not to contest your divorce?

$\square$ Yes $\square$ No

16. Do you think your spouse wanted to get a lawyer but didn't because you were using the kit? $\square$ Yes $\square$ No

17. Did you and your spouse agree in advance to procure the dissolution with the kit, or did you make the decision on your own?

$\square$ Agreed in advance $\square$ Own initiative

18. Did your divorce involve child custody? $\square$ Yes $\square$ No

19. Did your divorce involve a written property settlement? $\square$ Yes $\square$ No

20. If no, would you have felt more comfortable with one? $\square$ Yes $\square$ No

21. At the time you filed the complaint, were your spouse's whereabouts known to you? $\square$ Yes $\square$ No $\square$ Spouse in Conn.

22. Duration of marriage ......... Length of separation ......... Age ........ Education: Own . . . . . . Spouse ........ Income (joint) ......... Occupation at time of divorce:

Own ................... Spouse

23. Do you have any additional comments?

B. Telephone Interview Form for Kit Purchasers Who Had Not Commenced Pro Se Actions

1. Why did you initially decide to represent yourself?

Money: $\square$ Primary $\square$ Secondary

2. Have you definitely decided not to use the kit, or are you still undecided? $\square$ Definitely not $\square$ Undecided

3. Why did you decide not to proceed further with the kit?

\section{A. KIT RELATED}

No information concerning my situation in kit Child Custody

Child Support

Alimony 
_ Property Division

Absent Spouse

Other:

Felt kit was too complex, hard to understand

No one was available to answer questions

Wanted a lawyer's advice

Other

\section{B. PROCESS RELATED}

Couldn't resolve issues concerning property division

Couldn't resolve issues re alimony, child support, custody

Not sure about wanting divorce

Too busy to do myself

Too much hassle to do myself; not worth time, effort

Apprehensive about proceeding pro se

- Not sure what to expect

Couldn't do it without moral support

No reason to get divorce now

Needed divorce quickly

Other:

4. Were there any unresolved questions concerning alimony, child support, custody, or division of property? $\square$ Yes (coded above) $\square$ No

5. Would you prefer having a lawyer handling the action?

$$
\square \text { Yes } \square \text { No Why? }
$$

6. Do you think you would have proceeded with the kit if:

A. It had included information about your situation? $\square$ Yes $\square$ No

B. It had been easier to understand? $\square$ Yes $\square$ No

C. Assistance had been available? $\square$ Yes $\square$ No If so, of what sort?

7. At what point did you decide not to use the kit?

8. Did you receive any advice encouraging or discouraging you from using the kit? $\square$ Yes $\square$ No

9. How did you hear about the kit?

10. Duration of marriage ......... Length of separation ......... Age ......... Education: Own ........ Spouse ........ Income (joint) ......... Occupation at time of divorce:

Own ................. Spouse

11. Do you have any additional comments? 


\section{APPENDIX 6}

\section{Selected Connecticut Divorce Forms}

\section{A. Connecticut Practice Book Form 396 (Dissolution complaint) \\ Complaint for Dissolution of Marriage, with Custody of Children, and Alimony}

1. The plaintiff (whose maiden name was Mary Roe) and the defendant intermarried January 1,1950 , at

in the state (or country) of

2. The plaintiff (or defendant) has resided continuously in this state for at least twelve months next preceding the date of the filing of this complaint.

Or: The plaintiff (or defendant) removed into this state on the day of 19 , and has resided continuously therein since said date and the cause of dissolution of marriage set forth in this complaint arose after said removal.

Or: The plaintiff (or defendant) was domiciled in this state at the time of said marriage and before instituting this complaint had returned to this state with the intention of permanently remaining.

Or: (if none of the above jurisdictional bases exists): The plaintiff (or defendant) has resided continuously in this state since (insert date).

3. The marriage has broken down irretrievably.

Or: The parties have lived apart for a continuous period of at least the eighteen months immediately prior to the service of the complaint by reason of incompatibility and there is no reasonable prospect that they will be reconciled.

[examples of fault-based allegations omitted]

4. The plaintiff and the defendant have two minor children, issue of their marriage, John Doe, born

born , whose custody was on

awarded to by order of

court (naming it), or the responsibility for whose support was on by order of court (naming it), placed upon

of New Britain, Connecticut, or over whose persons on

by judgment of (name of court) of

was appointed guardian.

5. No other minor children have been born to the (plaintiff wife) (defendant wife) since the date of the marriage of the parties.

Or: The following other minor children have been born to the (plaintiff wife) (defendant wife) since the date of the marriage of the parties: Richard Doe, born

awarded to , whose custody was on , and Mary Doe, born court (naming it) or the 
responsibility for whose support was on

of

of

by judgment of court (naming it), placed upon

or over whose persons on

court (naming it)

by order , was appointed guardian.

of

6. The address of the plaintiff is plaintiff's social security number is was born on is

number is , and the defendant was born on

The
he plaintiff - The address of the defendant , the defendant's social security

7. (If the state of Connecticut is contributing or has contributed to the support or maintenance of a party or child of said party such fact should be stated in the complaint and a copy thereof served on the attorney general in accordance with the provisions of Sec. S0. Although the attorney general shall be a party to such cases, he need not be named in the writ of summons or summoned to appear.)

8. The defendant owns real and personal estate to the value of $\$ 15,000$, $o r$, The defendant has an income of $\$ 8000$ a year.

The plaintiff claims:

1. A dissolution of marriage (or a legal separation).

2. The custody of both the children.

3. Alimony.

4. An assignment of the defendant's estate, described in exhibit A attached hereto, pursuant to the provisions of Gen. Stat., $\$ 46-51$.

5. That her name be changed to Mary Roe (to be used in a dissolution of marriage case only).

(See Gen. Stat., $\$ \S ~ 46-32(c), 46-35,46-63$.

(Amended June 25, 1973, to take effect Sept. 4, 1973; amended June 24, 1974, to take effect Oct. 1, 1974; amended June 7, 1976, to take effect Oct. 1, 1976.) 
B. Form JD(COLP)-6001 (Connecticut Practice Book Form 379A)

(Financial Affidavit)

\section{Sfrorn Financial Statement}

עoGKer No. $\ldots \ldots \ldots \ldots \ldots \ldots \ldots \ldots \ldots \ldots \ldots \ldots \ldots \ldots$ SuPERIor Court at

Punntrof

DATE

v.

DefENDaNT

\section{Financial Affidavit}

Plaintiff $\square$ Defendant $\square$

I. Ixicosie (provide pertinent records)

A. Ircome From Principal Emplosment: (weekly arerage, not less than 13 reeks)

Gross Wrges \$ wik. Net Woges Itemize Deductions:

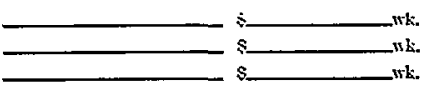

.
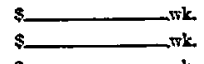

Total Deiuctions \$ $-w k$.

B. All Other Ireome (including in-kind compensation, gratuities, zents, interest, dividend, penaion, ete) 1. Sources of Income: (identify)

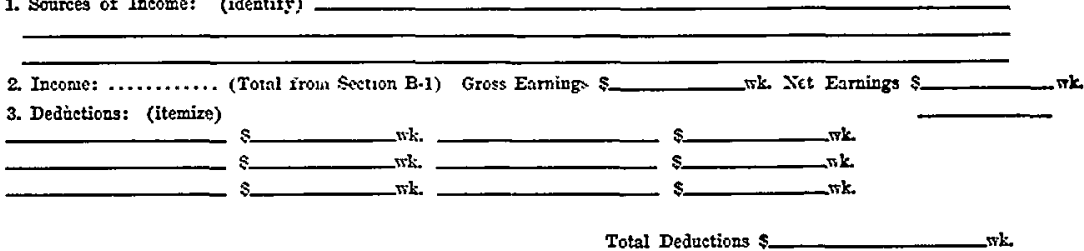

C. TOTAL WEExtY SET INcoste AIL SOTRCES

(Total A \& B) s

II. ASSETS

A. Real Estate

Home: Address

Value (estimste)

Other: Address

Value (estimate)

s____ Mortgage $s$

Equity $\$$

B. Alotor Vehicles

Year

Mortgage $S$

Equits s

Year Vodel Value

c. Other Personal Property (describe, list talue)

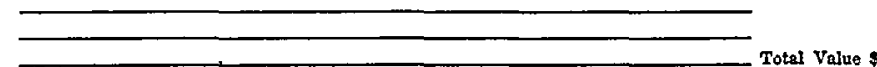

D. Bavings (describe, list value) 
E. Btocks, Bonds, Mutual Funds (list company, number of shares, value)

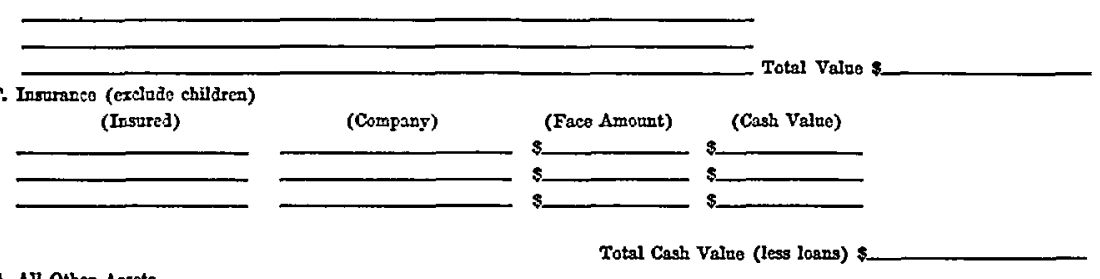

O. Arl Other Assets

Total Value

H. Totar Ar, Assets (Total A-C) \$

III. Lhabmitias

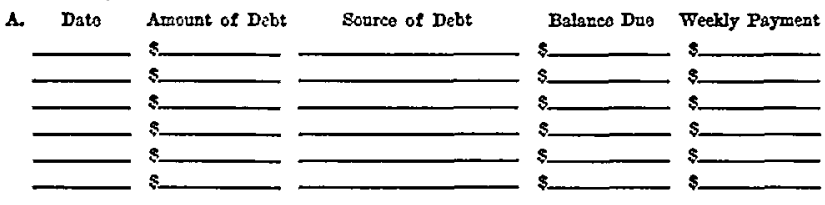

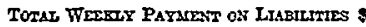

TOTAL LIABmitzes :

IV. Basto Expewses (Weekly)

1. Bent or Mrortgago (inel. prop-

eaty taxes \& 3ns.)

2. Utilitics (including heating)

3. Food

4. Payment on reeurrint debts

5. Aredieal and deatal expenses

6. Child support (order of court)

7. Clathing

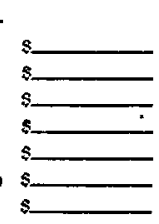

8. Insurance Premiums

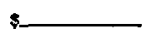

9. Transportation (including anto

insuraneo)

Other (specify below)

10.

11.

12.

13.

$\$$
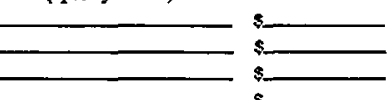

TOTAL TEEEZY EXPENSES $\$$

V. Suamary
A. Total Weekly Net Ineome (All Sources)
B. Total Cash Valuo of All Assets
o. Total Lhiblities
D. Total Treely Expenses

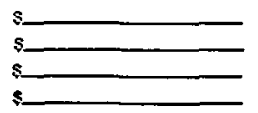

VI. Certtication

I hereby certify that the foregoing statement is aceurste to the best of my knowledge and that $I$ ean, if requested, submit documen. tation for all assets, labilitice, and axpensis listed abore

Aphant

Stcom and subseribed to bofore me

Notary Publio-Conmissioner of Superior Court 


\section{G. Form JD(COLP)-6002 (Claim for Uncontested Hearing)}

Docket No.

Superior COURT at

PunNings

DATE

V8.

Demendant

Glaim For Family Relations Uncontested Iist

I hereby claim the above matter for the uncontested list and certify:

1. ( ) This case is uncontested

2. ( ) All statutory residence requirements have been met. 3. ( ) All statutory stays have expired, ineluding a ninety day stay from the return day and any concilia-

4. Complete if the opposing party appears. () There is no amended complaint, eross complaint, or amended cross complaint on which a decree is
claimed.

or

( ) There is an amended complaint - cross complaint - amended cross complaint on which a decreo is clained but (cross off whichever is inapplicable) - the written consent of the opposing party is endorsed thereon or endorsed on a separate instrument - twenty days have elapsed from the filing of such amended complaint - cross complaint - amended cross complaint.

( ) Notice of intention to file this claim was served on the opposing party not less than ten days prior to the date hereof.

( ) Notice of intention to file this claim has been waived by written stipulation of the parties.

5. Complete if the opposing party does not appear.

( ) There is no amended complaint, cross complaint, or amended cross eomplaint which sets forth a cause of action or claim for relief not in the original complaint. or
( ) There is an amended complaint - cross complaint - amended cross complaint which sets forth a cause
of action or claim for relief not in the original complaint but twenty days have elapsed from tho fling of such amended complaint - cross complaint - amended cross complaint.

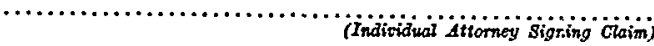

on behalf of (if applicable)

(Firm, Professional corporalion or öjice)

I hereby stipulate to waive prior ten days notice of the filing of this elaim and consent to any amended or sulstitute complaint - cross complaint - amendment to the complaint or cross complaint filed within the last twents days.

\section{(individual Attorney sigring chaim)}

on behalf of (if applicable) 
D. Connecticut Practice Book Annotated Form 396.25

(Affidavit that defendant is not in the military services)

\section{MILITARY AFFIDAVIT}

$\left.\begin{array}{l}\text { State of Connecticut } \\ \text { County of }\end{array}\right\}$ ss:

Personally appeared who made oath:

1. That she has had occasion to speak with the defendant over the last thirty days.

2. That she is satisfied that he resides at 00 South Street, Greenwich, Connecticut.

3. That in her opinion he is not presently within the military or naval service.

Subscribed and sworn to this

day of $\longrightarrow$, 19_, before me.

Commissioner of the Superior Court

E. Connecticut Practice Book Annotated Form 396.9

(Affidavit regarding custody of minor children)

\section{AFFIDAVIT RE GUSTODY PROGEEDINGS}

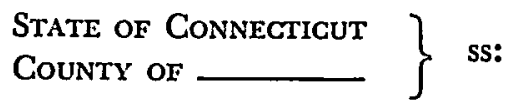

I, the complaining party in the above entitled action seeking custody of the minor(s), hereby aver that there is no proceeding pending in any other court affecting the custody of such minor(s) or any of them.

Subscribed and sworn to before me on the above date.

Commissioner of the Superior Court

A Reprinted by permission of the West Publishing Company from the Connecticut Praclice Book Annotated (1975 Supplement). 


\title{
F. Form JDSR 214
}

\section{(Decree form used when defendant has not filed an appearance)}

FISSOLUTION OF MARRAIAGE JUDGMENT - DefaDSt

No.

STATE OF CONNECTICUT

Present Hon. , Judge.

\section{JUDGMENT}

This action, by writ, and complaint, claiming a dissolution of the marriage of the parties and other relief, as on file, came to this Court on

\author{
and thence to
}

the present time, when the plaintiff appeared to prosecute said complaint, the defendant having made default of appearance.

The Court finds (1) that said writ and complaint was duly served on the defendant, and (2) that the defendant is not now nor within thirty days last prior hereto has been in the military or naval service of the United States, an affidavit re military service having been filed.

The Court, having heard the plaintiff, further finds the following:

1. The wife, by the name of

was lawfully married to the husband on

at

2. The

resided continuously in this State twelve months next before the date of the filing of the complaint or next preceding the date of this decree, and all statutory stays have expired.

3.

4. The plaintiff and defendant have

minor children, issue of said marriage, to wit:

5.

other minor children have been born to the wife since the date of marriage.

Whereupon it is adjudged that the marriage of the parties to this action be and it is hereby dissolved and they are each hereby declared to be single and unmarried, and that the care, custody and education of said minor children is hereby committed to the subject to the right of reasonable visitation in the

And that the pay to the and said minor children, subject to the right of reasonable visitation

Said support and alimony orders to be effective on notice to the defendant and filing thereof.

Judge.

County of

State of Connecticut

ss.

I hereby certify that the foregoing is a true copy of the original judgment in the herein named cause, as on file and of record appears.

In witness whereof, I have hereunto set my hand and the seal of said Court on

Clerk of the Superior Court. 
G. Mimeographed form used by New Haven Superior Court clerk's office to indicate errors made in filed forms

\author{
CLERK, SUPERIOR COURT \\ 235 CHURGH STREET \\ NEW HAVEN, CONNECTICUT 06510
}

\title{
THE ENCLOSED PAPERS ARE RETURNED FOR THE FOLLOWING REASONS:
}

( ) 1. Papers are not signed by individual attorney; does not include address of attorney. Papers not punched; insufficient margins. PB Sec. 79.

( ) 2. Certification needed PB Sec. 80.

( ) 3. Cannot be claimed for trial list. Issues not closed as to:

( ) 4. Already claimed for trial list.

( ) 5. Comply with PB Sec. 205 as amended September 4, 1974 (Privilege of Recall).

( ) 6. Pleading not closed. Case not subject to Motion for Reference. PB Sec. 353 Conn. Gen. Stat. Sec. 51-182M.

( ) 7. Case discontinued by Court. Case withdrawn.

( ) 8. Wrong Court or wrong case number.

( ) 9. Jury claim for six already on file.

( ) 10. Our records do not disclose a case captioned or returnable as the enclosed.

( ) 11. Comply with PB Sec. 154, 168 Re proposed order.

( ) 12. Rule to show cause necessary unless you indicate to us that opposing counsel has agreed to appear.

( ) 13. Brief required (PB Sec. 220).

( ) 14. File short calendar claim in ten days if no other pleading is filed. (PB Sec. 283).

( ) 15. No record of your appearance in this case.

( ) 16. No affidavit filed by either counsel certifying attempts to resolve differences; (PB Sec. 168 as amended).

( ) 17. Motion to place on uncontested list not proper. PB Sec. 377 repealed effective October 1, 1974. See PB Sec. 394.

( ) 18. Not proper claim for uncontested list. See PB Sec. 394.

RE: PB Sec. 394 (b) Notice of intent to claim to uncontested list

PB Sec. 394 (c) (4) Ninety days has not elapsed from return day.

PB Sec. 394 (c) (5) Indicate on claim form if complaint has been amended. 
( ) 19. This matter has already been set clown for a future hearing date.

( ) 20. Not a short calendar matter. File a claim for privileged court jury trial list (green slip) PB Sec. 213 (18) See 148 Conn. 435 at 439.

( ) 21. Motion to amend must have signed original of amendment attached to motion. PB 132 (c) effective September 15, 1975.

( ) 22. Motion to amend granted Amended pleading not on file. See PB Sec. 132 (a).

( ) 23. Motion for clisclosure is a pleading. No record of your compliance with motion on file. See 131 Conn. 266.

( ) 24. Disclosure filed Is this a motion for non-suit default for failure to fully disclose as to certain paragraphs?

( ) 25. Appearance does not comply with PB Sec. 42 (as amended effective November 1, 1974) RE:

Juris number, mailing address, $81 / 2^{\prime \prime}$ wide paper, signed by individual with his own name.

Does not state if appearance is in place of or in addition to appearance on file for attorney:

$$
\text { By }
$$

Assistant Clerk 